National Security Technologies LLC

\title{
THE HYDROGEOLOGIC CHARACTER OF THE LOWER TUFF CONFINING UNIT AND THE OAK SPRING BUTTE CONFINING UNIT IN THE TUFF PILE AREA OF CENTRAL YUCCA FLAT
}

\author{
July 2010 \\ Prepared for: \\ U.S. Department of Energy \\ National Nuclear Security Administration \\ Nevada Site Office \\ Las Vegas, Nevada
}

Prepared by:

Sigmund L. Drellack, Jr., Lance B. Prothro, Jose L. Gonzales, and Jennifer M. Mercadante Underground Test Area and Boreholes Programs and Operations National Security Technologies, LLC Las Vegas, Nevada 


\section{DISCLAIMER}

Reference herein to any specific commercial product, process, or service by trade name, trademark, manufacturer, or otherwise, does not necessarily constitute or imply its endorsement, recommendation, or favoring by the United States Government or any agency thereof.

Available for sale to the public from:

U.S. Department of Commerce

National Technical Information Service

5301 Shawnee Road

Alexandria, VA 22312

Telephone: 800.553 .6847

Fax: 703.605.6900

E-mail: orders@ntis.gov

Online ordering: http://www.ntis.gov/help/ordermethods.aspx

Available electronically at http://www.osti.gov/bridge

Available for a processing fee to U.S. Department of Energy and its contractors, in paper, from:

U.S. Department of Energy

Office of Scientific and Technical Information

P.O. Box 62

Oak Ridge, TN 37831-0062

Telephone: 865.576.8401

Fax: 865.576.5728

E-mail: reports@adonis.osti.gov 


\title{
The Hydrogeologic Character of the Lower Tuff Confining Unit and the Oak Spring Butte Confining Unit in the Tuff Pile Area of Central Yucca Flat
}

\author{
Prepared for: \\ U.S. Department of Energy \\ National Nuclear Security Administration \\ Nevada Site Office \\ Las Vegas, Nevada
}

Prepared by:

Sigmund L. Drellack, Jr., Lance B. Prothro, Jose L. Gonzales, and Jennifer M. Mercadante

Underground Test Area and Boreholes Programs and Operations

National Security Technologies, LLC

Las Vegas, Nevada

July 2010 
This page intentionally left blank. 


\section{Executive Summary}

The lower tuff confining unit (LTCU) in the Yucca Flat Corrective Action Unit (CAU) consists of a monotonous sequence of pervasively zeolitized volcanic tuff (i.e., mostly bedded with lesser nonwelded to poorly welded tuff; not fractured) (Bechtel Nevada, 2006). The LTCU is an important confining unit beneath Yucca Flat because it separates the alluvial and volcanic aquifers, where many underground nuclear tests were conducted, from the regional lower carbonate aquifer. Recent sub-CAU-scale modeling by Los Alamos National Laboratory in the Tuff Pile area of Yucca Flat (Boryta, et al., in review) includes postulated low-porosity, high-permeability zones (i.e., fractured welded-tuff aquifers) within the LTCU. This scenario indicates that such postulated low-porosity, high-permeability zones could provide fast-path lateral conduits to faults, and eventually to the lower carbonate aquifer. A fractured and faulted lower carbonate aquifer is postulated to provide a flow path(s) for underground test-derived contaminants to potential offsite receptors. The ramifications of such a scenario are obvious for groundwater flow and contaminant migration beneath Yucca Flat.

This paper describes the reasoning for not including postulated low-porosity, high-permeability zones within the LTCU in the Tuff Pile area or within the LTCU in the Yucca Flat CAU-scale model. Both observational and analytical data clearly indicate that the LTCU in the Tuff Pile area consists of pervasively zeolitic, nonwelded to poorly welded tuffs that are classified as tuff confining units (i.e., high-porosity, low-permeability). The position regarding the LTCU in the Tuff Pile area is summarized as follows:

- The LTCU in the Tuff Pile area consists of a monotonous sequence of predominantly zeolitic nonwelded to poorly welded tuffs, and thus is accurately characterized hydrogeologically as a tuff confining unit (aquitard) in the Yucca Flat-Climax Mine hydrostratigraphic framework model (Bechtel Nevada, 2006).

- $\quad$ No welded-tuff (or lava-flow aquifers), referred to as low-porosity, high-permeability zones in Boryta et al. (in review), are present within the LTCU in the Tuff Pile area.

- Fractures within the LTCU are poorly developed, a characteristic of zeolitic tuffs; and fracture distributions are independent of stratigraphic and lithologic units (Prothro, 2008).

- Groundwater flow and radionuclide transport will not be affected by laterally extensive zones of significantly higher permeability within the LTCU in the Tuff Pile area.

Although not the primary focus of this report, the hydrogeologic character of the Oak Spring Butte confining unit (OSBCU), located directly below the LTCU, is also discussed. The OSBCU is lithologically more diverse, and does include nonwelded to partially welded ash-flow tuffs. However, these older ash-flow tuffs are poorly welded and altered (zeolitic to quartzofeldspathic), and consequently, would tend to have properties similar to a tuff confining unit rather than a welded-tuff aquifer. 
This page intentionally left blank.

EX-2 


\section{Table of Contents}

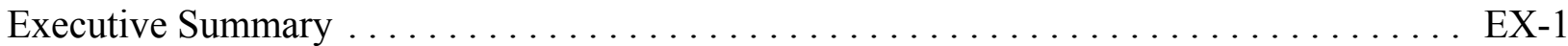

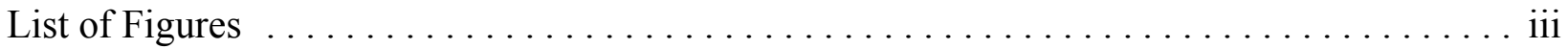

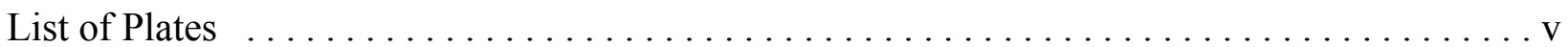

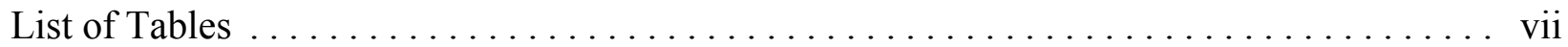

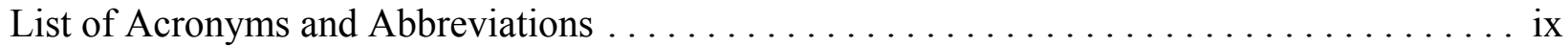

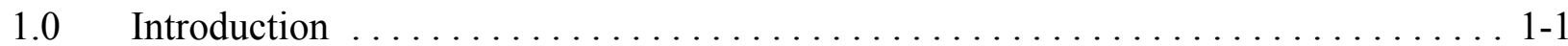

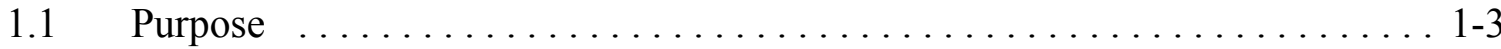

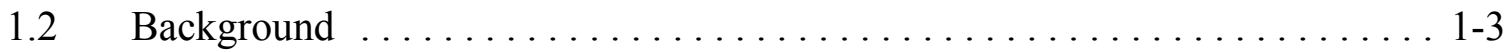

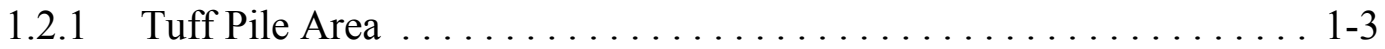

1.2.2 Tuff Pile Sub-CAU-Scale Models $\ldots \ldots \ldots \ldots \ldots \ldots \ldots \ldots \ldots$ 1-7

1.2.3 Yucca Flat-Climax Mine CAU-Scale Model ............... 1-8

1.3 Document Organization . . . . . . . . . . . . . . . . . . . . . . . . 1-8

2.0 Geology and Hydrogeology of the Tuff Pile Area ................... 2-1

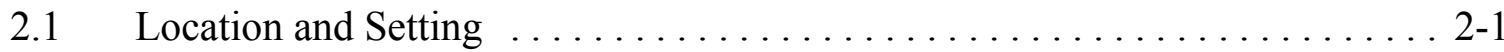

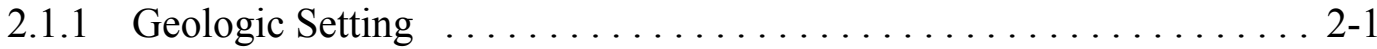

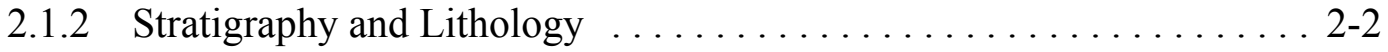

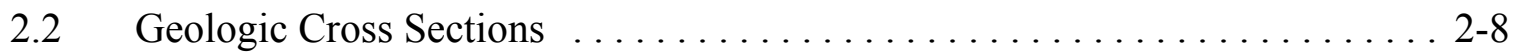

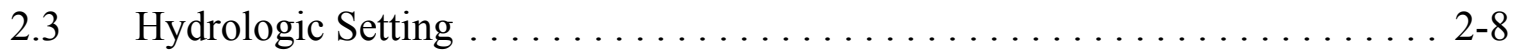

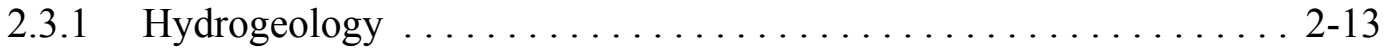

2.3.2 Water Levels ........................................ 2-13

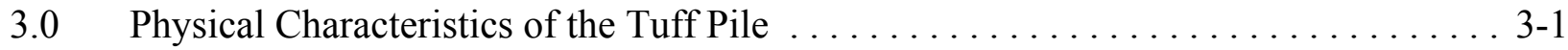

3.1 Mineralogic Characteristics of Volcanic Rocks $\ldots \ldots \ldots \ldots \ldots \ldots \ldots$. $3-1$

3.1.1 Alteration ............................... 3-1

3.1.2 Mineralogy of Tuff Confining Units ................. 3-3

3.1.3 Fracture Mineralization in Tuff Confining Units ............. 3-5

$3.2 \quad$ Physical Properties .............................. 3-5

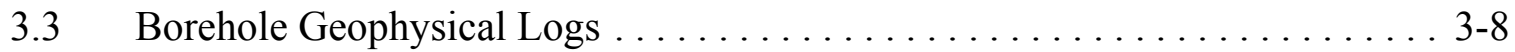

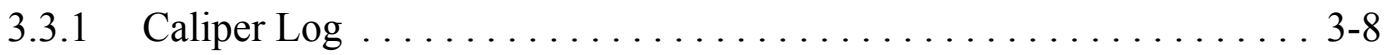

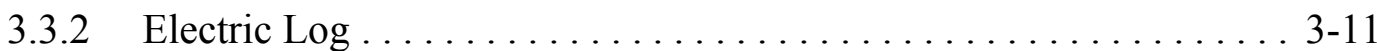

$4.0 \quad$ Hydrostratigraphy $\ldots \ldots \ldots \ldots \ldots \ldots \ldots \ldots \ldots \ldots \ldots \ldots \ldots \ldots .1$

4.1 Hydrostratigraphic Units of the Yucca Flat-Climax Mine HFM . . . . . . . . . 4-1 


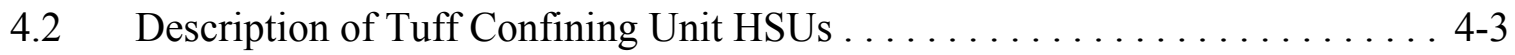

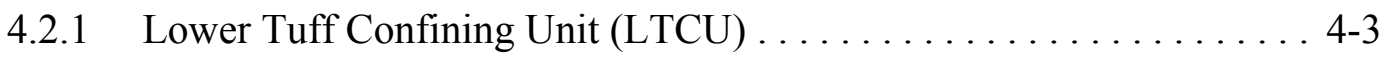

4.2.2 Oak Spring Butte Confining Unit (OSBCU) $\ldots \ldots \ldots \ldots \ldots \ldots .4-3$

4.2.3 Argillic Tuff Confining Unit (ATCU) $\ldots \ldots \ldots \ldots \ldots \ldots \ldots \ldots .4$

4.3 Potential Welded Ash-Flow Tuffs (Aquifers) within the LTCU and OSBCU . 4-5

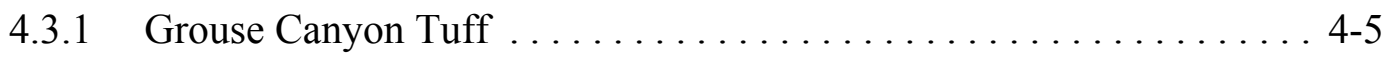

4.3.2 Tunnel Formation, Tunnel 4 Member, Beds 4E ............. 4-7

4.3.3 Tunnel Formation, Tunnel 3 Member, Beds 3BC ............ 4-14

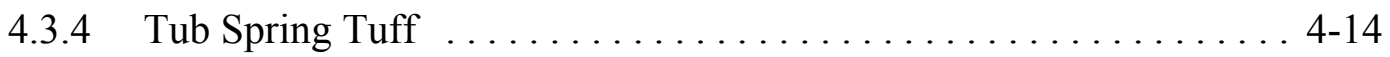

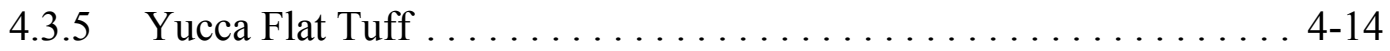

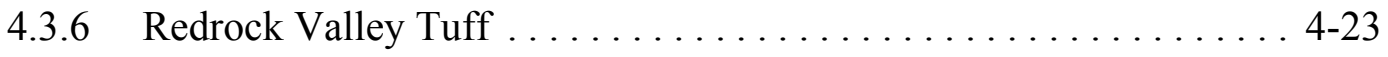

4.3.7 Tuff of Twin Peaks ........................ 4-23

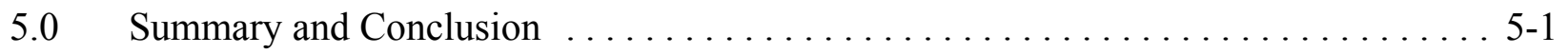

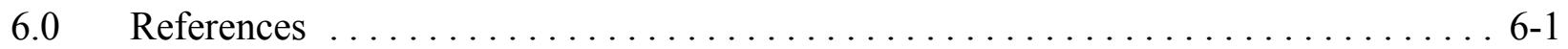

Appendix A Stratigraphic Data for Boreholes in the Tuff Pile Area

Distribution List 


\section{List of Figures}

1-1 Generalized Geologic Map of the Yucca Flat-Climax Mine Region, Showing the Location of the Tuff Pile Area . . . . . . . . . . . . . . . . . . . . . . . . . 1-2

1-2 Structure Contour Map of the Top of the Pre-Tertiary Surface in the Tuff Pile Area of Central Yucca Flat . . . . . . . . . . . . . . . . . . . . . . . . . . . . . . . . 1-4

1-3 Structure Contour Map of the Top of Zeolitization in the Tuff Pile Area of Central

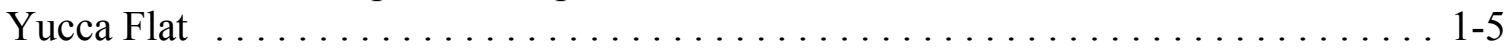

1-4 West-East Geologic Cross Section C-C' through the Central Tuff Pile Area . . . . . . . 1-6

2-1 Stratigraphic Column for the Tuff Pile Area of Yucca Flat $\ldots \ldots \ldots \ldots \ldots \ldots . . .2$

2-2 Locations of Boreholes and Cross Section Transects in the Area of the Tuff Pile . . . 2-9

2-3 South-North Geologic Cross Section A-A' through the Tuff Pile . . . . . . . . . . . 2-10

2-4 West-East Geologic Cross Section B-B' through the Tuff Pile at Exploratory Hole UE-7f . . . . . . . . . . . . . . . . . . .

2-5 West-East Geologic Cross Section D-D' through the Southern Portion of the Tuff Pile at Emplacement Hole U-3mf . . . . . . . . . . . . . . . . . . 2-12

2-6 West-East Hydrogeologic Cross Section E-E' through the Central Tuff Pile Area .. 2-14

3-1 Comparison of Vitric, Nonwelded Tuff and Devitrified, Densely Welded Ash-Flow Tuff from Exploratory Hole UE-12t\#3 . . . . . . . . . . . . . . . 3-6

3-2 Comparison of Zeolitized, Nonwelded Tuff and Densely Welded Ash-Flow Tuff

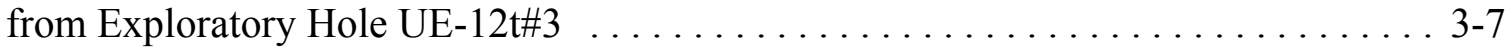

3-3 Average Calculated Porosity Values for Stratigraphic Units within the Tuff Pile Area 3-9

3-4 Location of Drill Holes from which Electric Logs are Presented in Plate 1 . . . . . 3-10

3-5 Resistivity Log from Well ER-EC-1 Showing Typical Signatures for Several Volcanic Rock Types . . . . . . . . . . . . . . . . . . . . . . . . 3-14

3-6 Continuous Resistivity Log Plot with Sample Mineralogy Data for Exploratory Hole UE-7f . . . . . . . . . . . . . . . . . . . . .

4-1 Correlation of Stratigraphic and Hydrostratigraphic Units in the Tuff Pile Area . . . . 4-2

4-2 Outcrop of Grouse Canyon Tuff: Densely Welded Ash-Flow Tuff (Tbg) above Zeolitic Ash-Fall Tuff (Tbgb), East Side of Rainier Mesa . . . . . . . . . . . 4-8

4-3 Depth to the Belted Range Aquifer in the Yucca Flat-Climax Mine Hydrostratigraphic Framework Model . . . . . . . . . . . . . . . . . . . . 4-9

4-4 Zeolitic Bedded Grouse Canyon Tuff (Tbgb) in Core from Exploratory Hole UE-7f 4-10

4-5 Comparison of Welded Grouse Canyon Ash-Flow Tuff (Tbg) from Exploratory Hole UE-12t\#3 and Zeolitic, Bedded Grouse Canyon Ash-Fall Tuff (Tbgb) from Exploratory Hole UE-7f . . . . . . . . . . . . . . . . . . . 4-11 


\section{List of Figures (continued)}

4-6 Tn4E-Equivalent Nonwelded Ash-Flow Tuff from Exploratory Hole UE-7f . . . . . 4-12

4-7 Close-up Photograph of Core of Tn4E-Equivalent Nonwelded Ash-Flow Tuff from Exploratory Hole UE-7f . . . . . . . . . . . . . . . . . . . . . 4-13

4-8a Zeolitic, Nonwelded Tunnel Bed 3BC-Equivalent from Exploratory Hole UE-7f

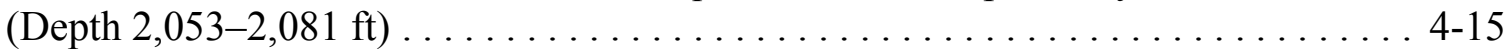

4-8b Zeolitic, Nonwelded Tunnel Bed 3BC-Equivalent from Exploratory Hole UE-7f

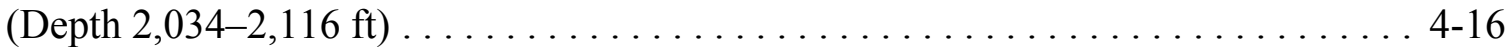

4-9 Outcrop of Welded Tub Spring Tuff on the East Face of Rainier Mesa Near U12n Tunnel

4-10 Outcrop of Tub Spring Tuff at Rainier Mesa $\ldots \ldots \ldots \ldots \ldots \ldots \ldots \ldots \ldots$. . . . . . . .

4-11 Zeolitic Tub Spring Ash-Fall Tuff from Exploratory Hole UE-7f . . . . . . . . . . . 4-19

4-12 Comparison of Welded Tub Spring Ash-Flow Tuff from Exploratory Hole UE-12t\#3 and Zeolitic Tub Spring Ash-Fall Tuff from Exploratory Hole UE-7f . . . . . . . . 4-20

4-13 Depth to the Tub Spring Aquifer in the Yucca Flat-Climax Mine Hydrostratigraphic Framework Model

4-14 Nonwelded to Partially Welded Yucca Flat Tuff in Exploratory Hole UE-7f . . . . 4-22

4-15 Outcrop of Welded Redrock Valley Ash-Flow Tuff in Redrock Valley, West of Yucca Flat ... . . . . . . . . . . . . . . . . . . . . . . 4-24

4-16 Close-up Photographs of Core of Redrock Valley Tuff from Hydrologic Test Hole U-3cn\#5 . . . . . . . . . . . . . . . . . . . . . . . . 4-25

4-17 Zeolitic, Nonwelded Tuff of Twin Peaks from Exploratory Hole UE-7f . . . . . . 4 4-26

4-18 Close-up Photograph of Core of Tuff of Twin Peaks from Exploratory Hole UE-7ax 4-27 


\section{List of Plates}

Plate $1 \quad$ North-South Cross Section through the Tuff Pile Area Showing Resistivity

Values for the Lower Tuff Confining Unit 
This page intentionally left blank. 


\section{List of Tables}

2-1 Quaternary and Tertiary Stratigraphic Units of the Central Yucca Flat Tuff Pile Area . . . . . . . . . . . . . . . . . . . . . . . . . . . . . . . . . . . . . . 2-4

2-2 Lithologic Descriptions for Typical Tuff Pile Geologic Units $\ldots \ldots \ldots \ldots \ldots \ldots$. 2-5

2-3 Hydrogeologic Units of the Tuff Pile Area $\ldots \ldots \ldots \ldots \ldots \ldots \ldots \ldots \ldots .2-15$

3-1 Holes in the Tuff Pile Area with Physical Properties and/or Mineralogical Data . . . . 3-2

3-2 Mineralogic Data for Geologic Units in the Tuff Pile Area ................. 3-4

3-3 Typical Apparent Resistivity Values of Several Formations and Rock Types in Yucca Flat ... . . . . . . . . . . . . . . . . . . . . . . . . . . . . . . . . . . 3-13

4-1 Stratigraphic Nomenclature and Correlation with Hydrogeologic and Hydrostratigraphic Units for the Tuff Pile Area . . . . . . . . . . . . . . . . . . . 4-6

A-1 Stratigraphic Data for Boreholes in the Tuff Pile Area $\ldots \ldots \ldots \ldots \ldots \ldots$ A-1 
This page intentionally left blank. 


\section{List of Acronyms and Abbreviations}

3-D three-dimensional

AA alluvial aquifer; valley-fill aquifer

ATCU argillic tuff confining unit

BN Bechtel Nevada

CA carbonate aquifer

CAU Corrective Action Unit

CCU clastic confining unit

$\mathrm{cm} \quad$ centimeter(s)

DOE/NV U.S. Department of Energy, Nevada Operations Office

$\mathrm{ft} \quad$ feet (foot)

HFM hydrostratigraphic framework model

HGU hydrogeologic unit

HSU hydrostratigraphic unit

IT International Technologies Corporation

LCA lower carbonate aquifer

LCCU lower clastic confining unit

LTCU lower tuff confining unit

m meter(s)

NAD North American Datum

NNSA/NSO U.S. Department of Energy, National Nuclear Security Administration Nevada Site Office

NSTec National Security Technologies, LLC

NTS Nevada Test Site

OSBCU Oak Spring Butte confining unit

SNJV Stoller-Navarro Joint Venture

SWL static water level

TCU tuff confining unit

TM-UVTA Timber Mountain upper vitric-tuff aquifer

TM-WTA Timber Mountain welded-tuff aquifer

TM-LVTA Timber Mountain lower vitric-tuff aquifer

TUBA Tub Spring aquifer

UGT underground nuclear test

UGTA Underground Test Area

VTA vitric-tuff aquifer

WTA welded-tuff aquifer

WTP Weapons Testing Program

XRD X-ray diffraction

YF-CM Yucca Flat-Climax Mine 
This page intentionally left blank. 


\subsection{Introduction}

The Environmental Restoration Project of the U.S. Department of Energy, National Nuclear Security Administration Nevada Site Office (NNSA/NSO) initiated the Underground Test Area (UGTA) Sub-Project to investigate the extent of groundwater contamination at the Nevada Test Site (NTS) and surrounding areas due to past underground nuclear testing. The UGTA investigation focuses on the geology and hydrology of the NTS to estimate the direction and rate at which contaminants are transported by groundwater flow. Framework models developed at the scale of individual corrective action units (CAUs) will give modelers the ability to test a range of potential groundwater flow and contamination scenarios by allowing them to apply flow and transport algorithms and vary parameters for each hydrostratigraphic unit (HSU). Sub-CAU-scale models contain greater hydrogeologic detail and are sometimes used to explore alternative scenarios, investigate the effects of varying hydraulic properties, and test parameter uncertainties.

This report addresses the hydrogeologic character of the Tuff Pile area, part of the Yucca FlatClimax Mine (YF-CM) CAU, located in central Yucca Flat (Figure 1-1). In particular, this study concentrates on rocks that are categorized hydrogeologically as tuff confining units (TCUs) and that form the HSUs known as lower tuff confining unit (LTCU) and Oak Spring Butte confining unit (OSBCU). These rocks directly overlie the carbonate aquifer in central Yucca Flat and are thus an important hydrogeologic unit (HGU). A fractured and faulted lower carbonate aquifer is postulated to provide a flow path(s) for underground test-derived contaminants to potential offsite receptors.

A recent sub-CAU-scale modeling effort (Boryta, et al., in review) evaluated the effect of anomalously high groundwater heads in the Tuff Pile area, and included low-porosity, highpermeability zones (i.e., fractured welded tuffs) within the LTCU in the analysis - a scenario that might facilitate the transport of underground nuclear test (UGT) contaminants away from test cavities. However, detailed geologic studies, including detailed lithologic descriptions from numerous boreholes, geophysical logs, and physical property measurements, clearly show that there are no strongly welded tuffs (i.e., welded-tuff aquifers [WTAs]) in the Tuff Pile area below the Timber Mountain Group. Therefore, inclusion of welded tuffs (i.e., WTAs) within the LTCU is not supported by the available data. 


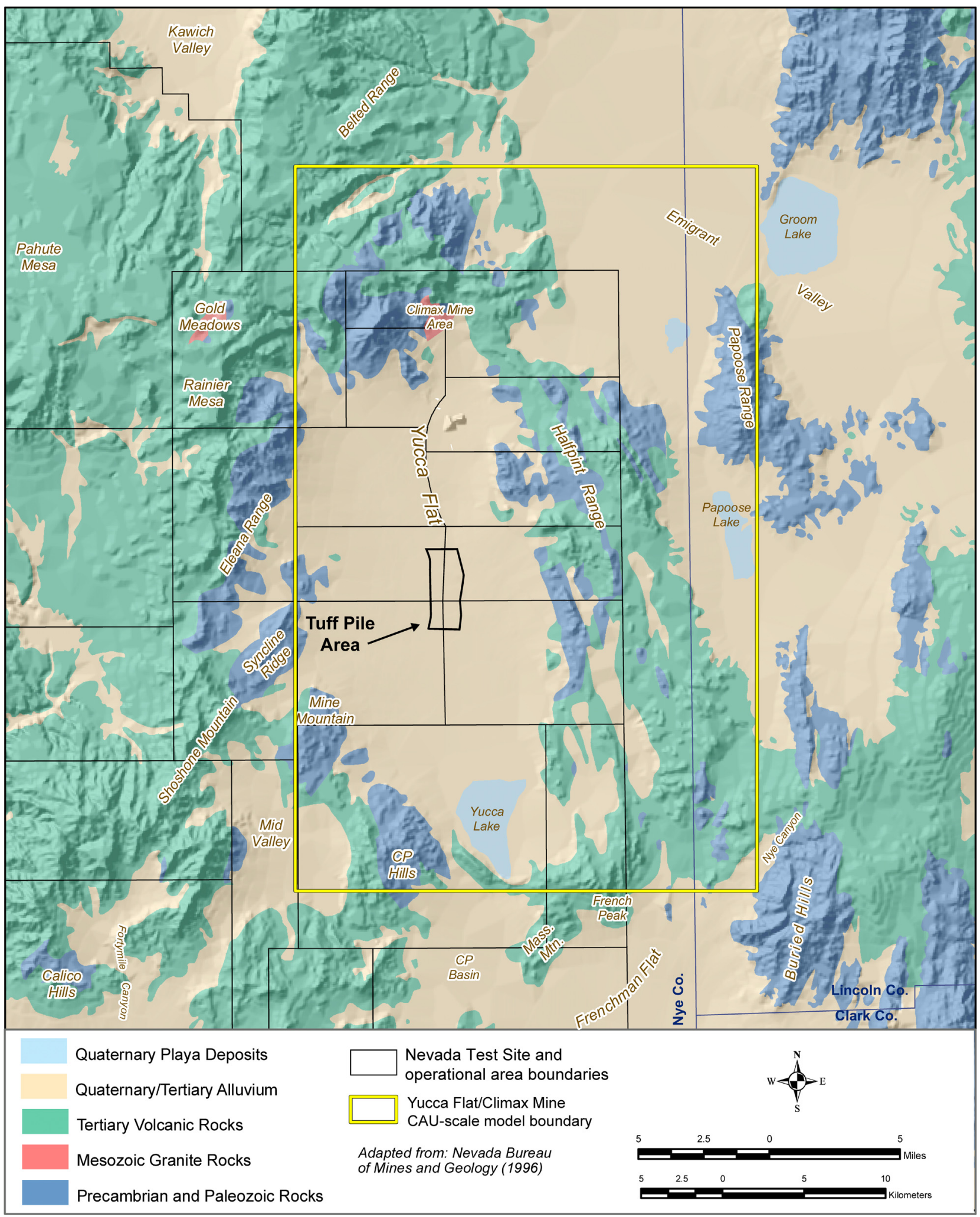

Figure 1-1

Generalized Geologic Map of the Yucca Flat-Climax Mine Region, Showing the Location of the Tuff Pile Area 


\subsection{Purpose}

The primary purpose of this study is to clarify the hydrogeologic framework, in particular the LTCU, of the Tuff Pile area in central Yucca Flat. This will be accomplished using stratigraphic, lithologic, mineralogic, physical properties, and geophysical log data to demonstrate that no welded tuffs (i.e., WTAs) are present within the LTCU in central Yucca Flat.

\subsection{Background}

The original Tuff Pile testing area, the recent Tuff Pile sub-CAU-scale model, and the YF-CM CAU-scale hydrostratigraphic framework model (HFM) are introduced in this section.

\subsubsection{Tuff Pile Area}

Numerous UGTs were conducted in a portion of central Yucca Flat between the Topgallant and Yucca faults, designated at the time as "Tuff Pile 1" (referred to as the "Tuff Pile" throughout this report). It is important to note that the Tuff Pile was originally defined on the basis of its well known, consistent, and predictable geologic characteristics as related to the characterization requirements for containment of UGTs (including rock density and porosity). This area was well characterized for underground testing on the basis of lithologic samples (including continuous core), physical properties data, and geophysical logs, as documented by App and Marusak (1983; 1997). The area encompasses about 8 square kilometers ( 3.1 square miles) and includes parts of NTS Areas 1, 3, 4, and 7 (Figure 1-1). Its southern boundary is at Nevada State Plane Coordinates (North American Datum of 1927 [NAD 27]) N 256,000 meters (m) (N 840,000 feet [ft]), and its northern boundary is at N 260,600 $\mathrm{m}$ (N 855,000 ft). The rocks characterized for the Tuff Pile extend from the surface to the bottom of the volcanic section, which ranges from about $595 \mathrm{~m}(1,950 \mathrm{ft})$ below the ground surface on the northeast margin, to about $1,085 \mathrm{~m}$ $(3,560 \mathrm{ft})$ deep along the southwest side.

The geology and material properties for this area are well known and predictable (App and Marusak, 1983; 1997). The rocks of the Tuff Pile consist of Tertiary-age tuff and the overlying alluvial stratigraphic sequence typical of central Yucca Flat. Structurally, this area is a westdipping half-graben, bounded on the east and west by large, basin-forming faults. Both the Yucca and Topgallant faults dip to the east and have significant vertical displacement. This structural configuration can be seen in the structural contour maps of the pre-Tertiary surface (Figure 1-2) and the top of zeolitization (Figure 1-3) and on the west-east geologic cross section depicted in Figure 1-4. 

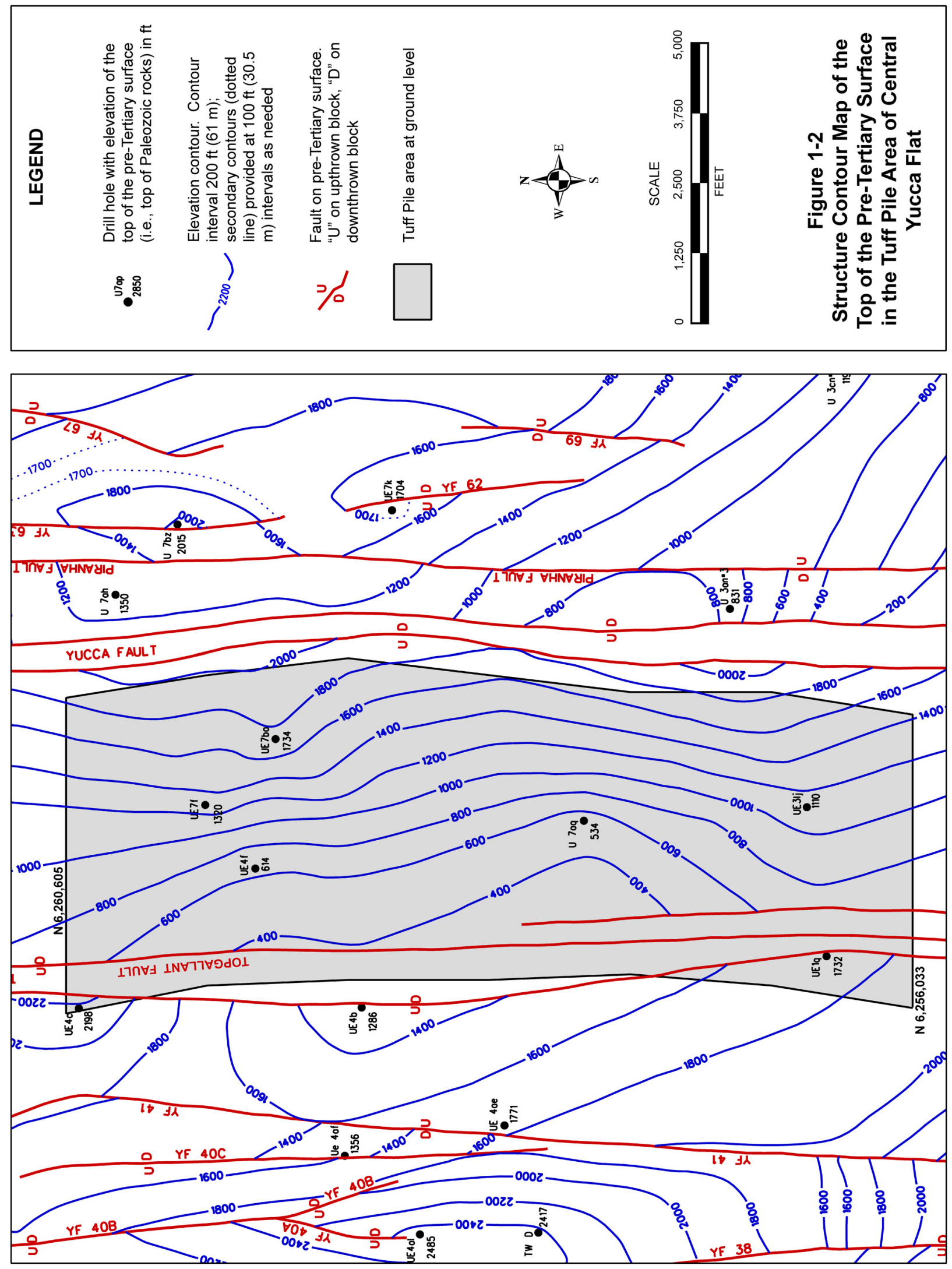

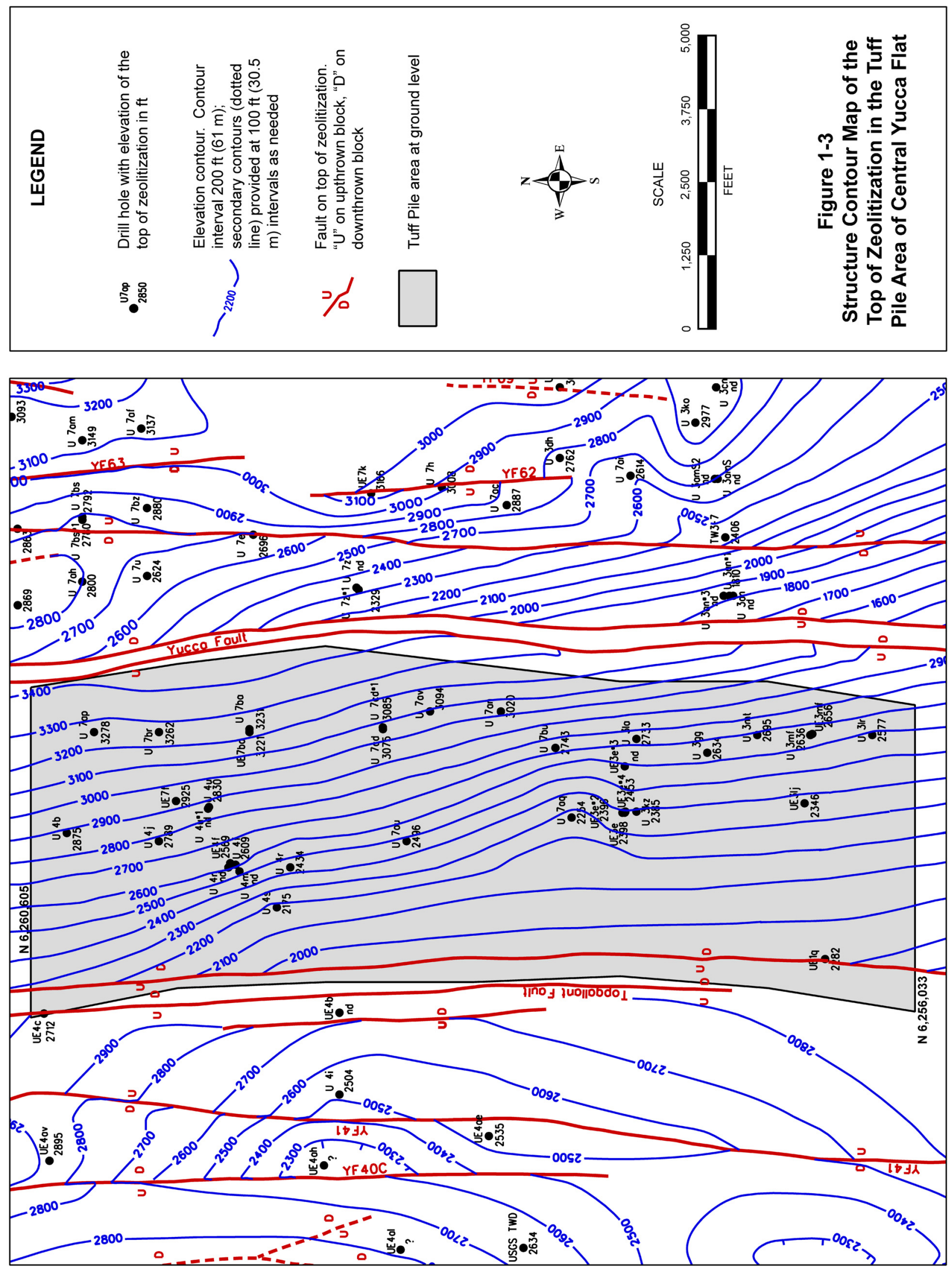


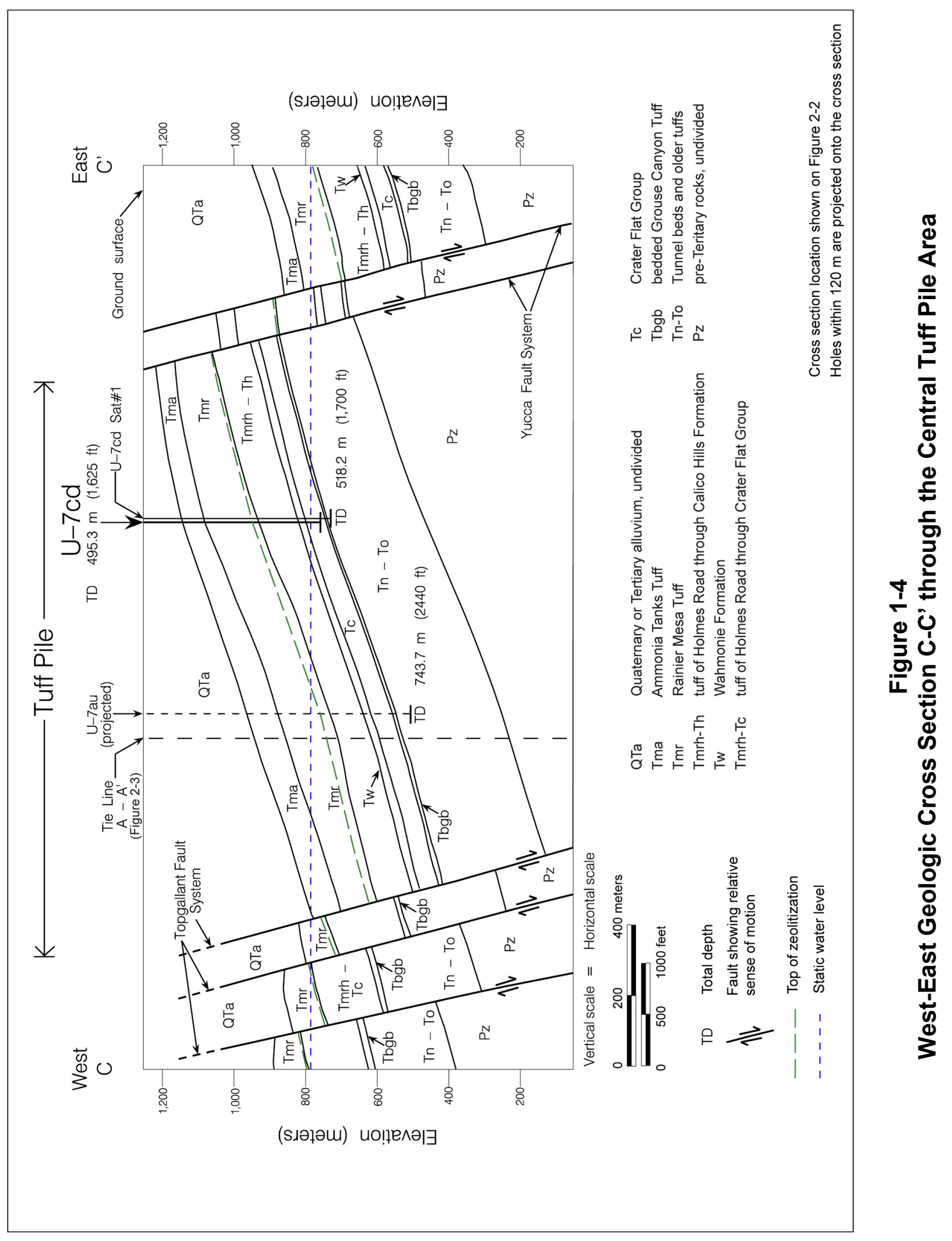


The first UGT was conducted in the Tuff Pile area in 1976. After more than seven years of geological investigations and underground nuclear testing, it was accepted in 1983 that new UGT sites in the Tuff Pile area could be confidently characterized without the need to collect the comprehensive suite of geophysical logs and physical properties measurements that were normally obtained to characterize a proposed UGT site. App and Marusak (1983) showed that physical properties could be extrapolated by location to within a few percent, so for each subsequent emplacement hole, a standard set of drill cuttings samples was collected and the geophysical logging suite was reduced to a caliper log and an electric log.

It is important to note that there is a diverse and robust dataset for this particular area. Between 1976 and 1991, 25 UGTs were conducted in the Tuff Pile area (U.S. Department of Energy, Nevada Operations Office [DOE/NV], 2000). Fourteen boreholes were drilled after the adoption of the Tuff Pile concept in 1983, and no "surprises" or deviations from expectations were found (App and Marusak, 1997). The primary dataset consists of 45 drill holes (including six core holes and eight rotary-drilled holes that penetrated the entire volcanic section), three two-dimensional seismic lines, and petrographic, mineralogic, and physical properties analyses.

The presence of low-porosity, high-permeability zones within the zeolitized volcanic section in the Tuff Pile area would have been of extreme importance and interest to Weapons Testing Program (WTP) scientists. If such zones had been present, they would have been thoroughly characterized and their distribution carefully mapped.

\subsubsection{Tuff Pile Sub-CAU-Scale Models}

Several wells in and near the Tuff Pile that access the low permeability, zeolitized tuff section display anomalously high hydraulic heads, as reported by Wohletz and Hawkins (1998).

Wohletz et al. (1999) conducted initial scoping numerical simulations to test the hypothesis that these anomalous values were caused by UGTs. Wohletz et al. (1999) also explored the range of rock permeability and porosity values that could result in such "over-pressure," the time span required for pressures to dissipate, and whether this effect could facilitate migration of contaminated groundwater from individual units to the underlying regional carbonate aquifer.

The most recent modeling effort by Boryta, et al. (in review) builds on that earlier work. Boryta et al. (in review) presents compilations of data and analyses from investigations of the effect of anomalously high heads on groundwater flow and radionuclide transport in the Tuff Pile area. This sub-CAU-scale modeling includes low-porosity, high-permeability zones (i.e., WTAs) within the otherwise zeolitic TCUs that collectively constitute the LTCU and OSBCU HSUs, and indicates that these low-porosity, high-permeability zones would provide fast-path lateral 
conduits to faults, and eventually to the lower carbonate aquifer (LCA), also referred to as the regional aquifer.

This scenario is of concern because the conductive LCA could provide flow paths for UGT-derived contaminants to potential offsite receptors. Boryta et al. (in review) also includes a new stratigraphic framework model comprising 28 separate Tertiary volcanic units above the carbonate aquifer, with 6 different material classification types (welded-tuff aquifer, bedded tuff, tuff confining unit, partially to moderately welded ash-flow tuff, undifferentiated older tuff, and paleocolluvium). This was intended to provide higher resolution to the new sub-CAU model but did not specifically incorporate hydrogeologic properties of the units.

\subsubsection{Yucca Flat-Climax Mine CAU-Scale Model}

A CAU-scale HFM of Yucca Flat and the area immediately surrounding the basin was developed for the UGTA Sub-Project in 2006 (Bechtel Nevada [BN], 2006) (model area shown in Figure 1-1). This three-dimensional (3-D) HFM consists of 178 faults and 25 HSUs, including 8 volcanic aquifers and 5 volcanic confining units. The HSUs were defined on the basis of stratigraphy and hydrogeologic character, as described in BN (2006) and summarized in Section 4.1 of this report.

In the Tuff Pile area in central Yucca Flat, the CAU-scale model was built with nine HSUs, including two volcanic aquifers and three volcanic confining units. Much of the hydrogeologic information for the Tuff Pile area presented here is from the YF-CM HFM document (BN, 2006) and from the studies and data that went into building that model.

\subsection{Document Organization}

In this report, the authors present information about the character of the Tuff Pile rocks, concentrating on the properties of the TCUs in the Tuff Pile area. General information on the geology of the area is presented first, to provide background information. This is followed by

descriptions of the physical characteristics of the Tuff Pile rocks, including methods of characterization, to show that the TCUs identified for use in the UGTA HFM for the Yucca Flat area do not contain significant low-porosity, high-permeability zones, such as those exhibited by strongly welded tuff. Examples of the wide variety of data supporting this conclusion are presented next. Finally, discussions of individual stratigraphic units assigned to TCU HSUs that were postulated by Boryta et al. (in review) to have the potential to contain aquifer sections are provided, with data and arguments supporting the conclusion that none contain significant aquifers. 


\subsection{Geology and Hydrogeology of the Tuff Pile Area}

This section provides descriptions of the physiographic, geologic, and hydrologic setting of the Yucca Flat area. This summary was compiled from various sources, including BN (2006) and Prothro (2005), where additional information can be found.

\section{$2.1 \quad$ Location and Setting}

Yucca Flat is a topographically closed basin with a playa (a seasonally dry lake) at its southern end (Figure 1-1). The geomorphology of Yucca Flat is typical of the arid, inter-mountain basins found throughout the Basin and Range province of Nevada and adjoining states. Faulted and tilted blocks of Tertiary-age volcanic rocks and underlying Precambrian and Paleozoic sedimentary rocks form low ranges around the basin (Figure 1-1). These rocks also compose the down-dropped "basement" of the basin, which is now covered by alluvium. The Tuff Pile area is located in the relatively flat central portion of Yucca Flat. Ground elevations are between 1,236.6 and 1,268.6 $\mathrm{m}(4,057 \mathrm{ft}$ and 4,162 ft). Twenty-five UGTs were conducted in the Tuff Pile area in vertical emplacement holes within alluvial and volcanic rocks.

\subsubsection{Geologic Setting}

Yucca Flat is a north-south-elongated, Neogene-age basin formed in response to basin-and-range extension. Large down-to-the-east normal faults such as the Carpetbag, Topgallant, and Yucca faults are located near the center of the basin. These faults drop down the east side of Yucca Flat basin, forming the deep west-tilted Yucca Flat basin proper (Figures 1-2, 1-3, and 1-4). These structural features significantly influenced the present attitude of the volcanic rocks and the distribution and thickness of the alluvium in Yucca Flat. Numerous antithetic and synthetic faults occur throughout the basin.

The volcanic rocks beneath the Tuff Pile area, and the Yucca Flat basin in general, range in age from approximately 11.5 to 15 million years and consist mostly of nonwelded to densely welded ash-flow tuff, ash-fall deposits, and reworked tuff. These types of volcanic deposits typically contain large proportions of glass when originally deposited. However, with time and particularly in the presence of groundwater, the glass within the poorly welded rocks tends to alter to zeolite (Hoover, 1968). This alteration significantly reduces the effective (interstitial) porosity of the rocks (Thordarson, 1965; Blankennagel and Weir, 1973; Winograd and Thordarson, 1975). As the Yucca Flat basin developed, the unaltered glassy volcanic rocks were dropped down below the water table and altered to zeolite, significantly reducing the ability of 
these rocks to transmit water, and forming the TCU (see Section 3.1 in this report and also Prothro, 2005).

As mentioned previously, the position of the TCU below the overlying alluvial and volcanic aquifers in which most of the UGTs were conducted, and above the Paleozoic rocks that form the regional aquifer, make the TCU an important HGU (see Section 2.3.1 for a discussion of the hydrogeology) in the Yucca Flat vicinity.

\subsubsection{Stratigraphy and Lithology}

The stratigraphic system for the Tuff Pile area is well understood, based on detailed investigations by geoscientists associated with the WTP (App and Marusak, 1983; 1997;

Drellack and Thompson, 1990; Drellack, 1994a; Hawkins et al., 1988; Thompson, 1991) and associated extensive petrographic work (Warren et al., 2003).

The stratigraphic section in the Tuff Pile area, from the oldest to the youngest, consists of Paleozoic-age carbonate rocks, Tertiary-age volcanic rocks, and Tertiary- and Quaternary-age alluvium. The stratigraphy of the rocks in the Tuff Pile area is illustrated in Figure 2-1. Table 2-1 lists the Quaternary and Tertiary stratigraphic units common to the central Yucca Flat basin and the Tuff Pile area. Stratigraphic unit tops for drill holes located within the Tuff Pile area are provided in Appendix A.

Table 2-2 gives lithologic descriptions for units in a typical section of the Tuff Pile area. These descriptions were prepared using a series of reports that contain detailed lithologic logs for 45 holes drilled in the Tuff Pile area between 1963 and 1992. The original logs can be found in the references listed at the bottom of Table 2-2. 


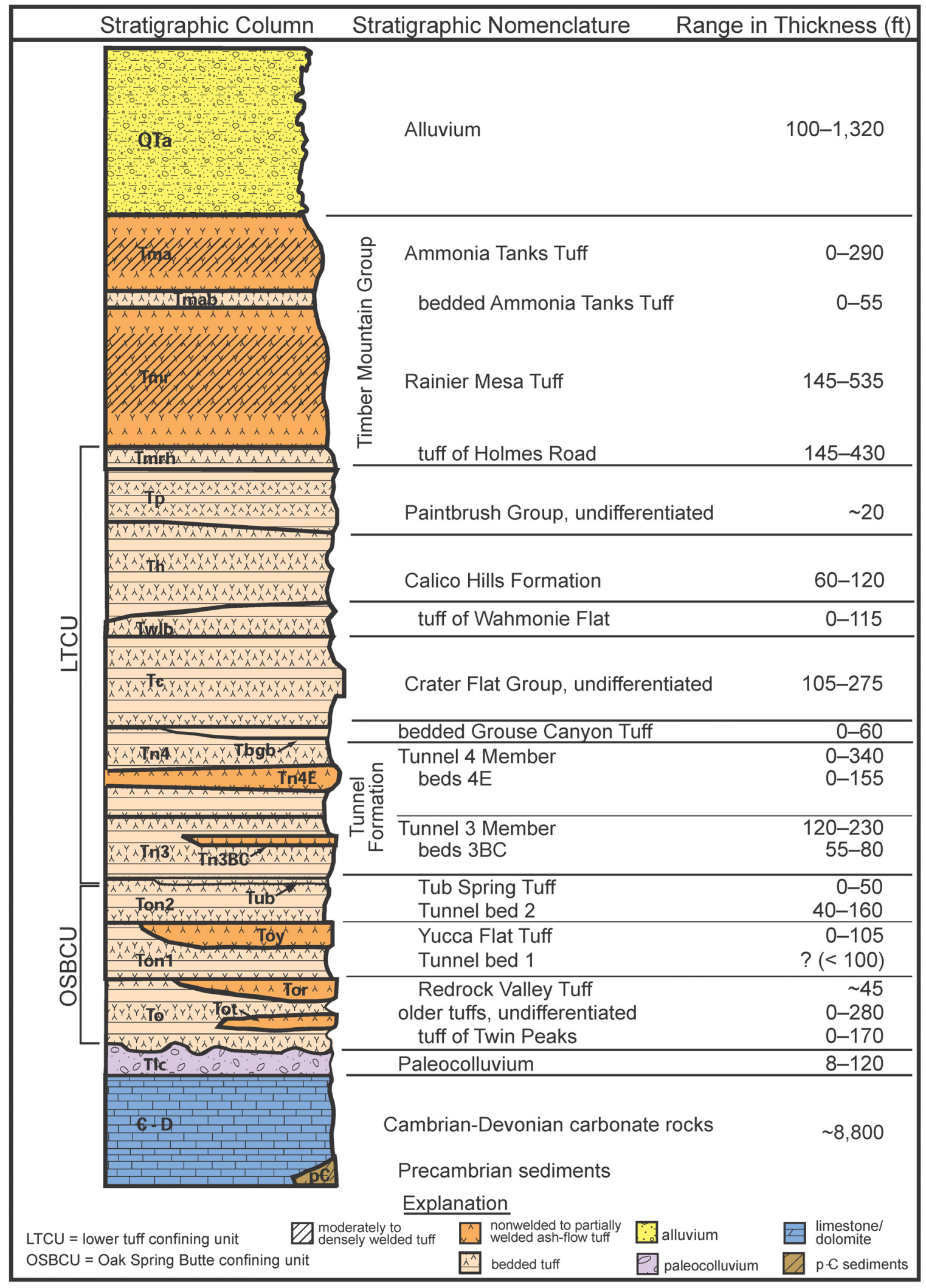

Figure 2-1

Stratigraphic Column for the Tuff Pile Area of Yucca Flat 
Table 2-1

Quaternary and Tertiary Stratigraphic Units of the Central Yucca Flat Tuff Pile Area

\begin{tabular}{|c|c|}
\hline Stratigraphic Assemblages and Major Units ${ }^{\text {a, } b}$ & Volcanic Sources $^{c}$ \\
\hline $\begin{array}{l}\text { Quaternary and Tertiary Sediments } \\
\text { young alluvium (Qay) } \\
\text { intermediate alluvium (Qai) } \\
\text { Quaternary-Tertiary alluvium (QTa) }\end{array}$ & Not applicable \\
\hline $\begin{array}{l}\text { Timber Mountain Group (Tm) } \\
\text { Ammonia Tanks Tuff (Tma) } \\
\text { bedded Ammonia Tanks Tuff (Tmab) } \\
\text { Rainier Mesa Tuff (Tmr) } \\
\text { tuff of Holmes Road (Tmrh) }\end{array}$ & $\begin{array}{l}\text { Timber Mountain Caldera Complex } \\
\text { Ammonia Tanks Caldera } \\
\text { Rainier Mesa Caldera }\end{array}$ \\
\hline $\begin{array}{l}\text { Paintbrush Group (Tp) } \\
\text { undifferentiated bedded units }\end{array}$ & $\begin{array}{c}\text { Claim Canyon Caldera } \\
\text { Unknown }\end{array}$ \\
\hline Calico Hills Formation (Th) & Unknown \\
\hline $\begin{array}{l}\text { Wahmonie Formation (Tw) } \\
\text { tuff of Wahmonie Flat (Twlb) }\end{array}$ & Wahmonie Volcanic Center \\
\hline $\begin{array}{l}\text { Crater Flat Group (Tc) } \\
\text { Prow Pass Tuff (Tcp) } \\
\text { Bullfrog Tuff (Tcb) } \\
\text { Tram Tuff (Tct) } \\
\text { Belted Range Group (Tb) } \\
\text { bedded Grouse Canyon Tuff (Tbgb) }\end{array}$ & $\begin{array}{l}\text { Silent Canyon Caldera Complex } \\
\text { Area } 20 \text { Caldera } \\
\text { Grouse Canyon Caldera }\end{array}$ \\
\hline $\begin{array}{l}\text { Tunnel Formation (Tn) } \\
\text { Tunnel bed } 4 \text { member (Tn4) beds 4K, 4J, 4FGH, } \\
\text { 4E-equivalent, ABCD } \\
\text { Tunnel bed } 3 \text { member (Tn3) beds 3D, 3BC-equivalent, 3A }\end{array}$ & Unknown \\
\hline $\begin{array}{c}\text { Volcanics of Big Dome (Tu) } \\
\text { Tub Spring Tuff (Tub) }\end{array}$ & Unknown \\
\hline $\begin{array}{l}\text { Volcanics of Oak Spring Butte (To) } \\
\text { Tunnel bed } 2 \text { (Ton2) } \\
\text { Yucca Flat Tuff (Toy) } \\
\text { Tunnel bed } 1 \text { (Ton1) } \\
\text { Redrock Valley Tuff (Tor) } \\
\text { tuff of Twin Peaks (Tot) } \\
\text { older volcanics, undivided (To) }\end{array}$ & $\begin{array}{r}\text { Unknown } \\
\text { Redrock Valley Caldera }\end{array}$ \\
\hline $\begin{array}{l}\text { Paleocolluvium (TI) } \\
\text { paleocolluvium, undivided }\end{array}$ & Not applicable \\
\hline
\end{tabular}

a Compiled from Slate et al. (1999) and Ferguson et al. (1994)

b Letters in parentheses are stratigraphic unit map symbols

c Sources, where known, from Sawyer et al. (1994) 
Table 2-2

Lithologic Descriptions for Typical Tuff Pile Geologic Units

(Summarized from detailed lithologic logs ${ }^{a}$ )

\begin{tabular}{|c|c|c|c|}
\hline $\begin{array}{l}\text { Stratigraphic Unit } \\
\text { (Map Symbol) }\end{array}$ & Lithologic Description & $\begin{array}{c}\text { Typical } \\
\text { Thickness } \\
\text { (feet) }\end{array}$ & $\begin{array}{c}\text { Average } \\
\text { Thickness } \\
\text { (feet) }\end{array}$ \\
\hline Alluvium (QTa) & $\begin{array}{l}\text { Alluvium: Generally moderate-yellowish-brown; } \\
\text { poorly to non-indurated; subangular to subrounded; } \\
\text { poorly sorted; sand to gravel sizes; predominately } \\
\text { tuffaceous with } 5 \text { to } 10 \text { percent Paleozoic rock } \\
\text { fragments; calcareous. }\end{array}$ & $100-1,320$ & 710 \\
\hline $\begin{array}{l}\text { Ammonia Tanks } \\
\text { Tuff (Tma) }\end{array}$ & $\begin{array}{l}\text { Ash-Flow Tuff: Light-brown to pale-red becoming } \\
\text { more grayish near the base of the section. Nonwelded } \\
\text { to partially welded; vitric. The rocks contain abundant } \\
\text { phenocrysts of sanidine, quartz, and sodic plagioclase, } \\
\text { with less abundant biotite and clinopyroxene; trace of } \\
\text { sphene. }\end{array}$ & 0-290 & 198 \\
\hline $\begin{array}{l}\text { bedded Ammonia } \\
\text { Tanks Tuff (Tmab) }\end{array}$ & $\begin{array}{l}\text { Bedded Tuff: Reworked and ash-fall tuff; } \\
\text { brownish-gray to light-olive-gray; poorly indurated; } \\
\text { vitric; common white to very-light-gray pumice; scarce } \\
\text { mafic minerals; very scarce sphene. Can be weakly } \\
\text { calcareous. }\end{array}$ & $0-55$ & 21 \\
\hline $\begin{array}{l}\text { Rainier Mesa Tuff } \\
\text { (Tmr) }\end{array}$ & $\begin{array}{l}\text { Ash-Flow Tuff: A compound cooling unit of } \\
\text { nonwelded to densely welded rhyolitic to quartz-latitic } \\
\text { tuff; vitric to devitrified (welded). Usually there is a } \\
6.1 \mathrm{~m}(20 \mathrm{ft}) \text { thick conspicuous vitrophyre present } \\
\text { about } 30 \mathrm{~m} \text { (100 ft) below the top of the formation. Unit } \\
\text { is usually pale-red, grayish-red to grayish-red-purple } \\
\text { and reddish-brown. The rocks contain } 15-30 \text { percent } \\
\text { phenocrysts of mainly sanidine, quartz, sodic } \\
\text { plagioclase, and biotite. Lithic fragments are scarce to } \\
\text { rare. }\end{array}$ & $145-535$ & 465 \\
\hline $\begin{array}{l}\text { tuff of Holmes } \\
\text { Road (Tmrh) }\end{array}$ & $\begin{array}{l}\text { Bedded Tuff: Reworked and ash-fall tuff; pink to } \\
\text { brown; pumice-rich; usually vitric; phenocrysts include } \\
\text { scarce to common sanidine, plagioclase, and quartz. } \\
\text { Scarce mafic minerals and trace of sphene. }\end{array}$ & $145-430$ & 303 \\
\hline $\begin{array}{l}\text { Paintbrush Group, } \\
\text { undifferentiated } \\
\text { (Tp) }\end{array}$ & $\begin{array}{l}\text { Bedded Tuff: Reworked and ash-fall tuffs; } \\
\text { yellowish-gray, grayish-yellow to moderate-yellowish- } \\
\text { brown. Partially indurated; normally zeolitized; } \\
\text { common small, very-pale-orange pumice; minor } \\
\text { feldspar and biotite phenocrysts and trace of sphene. }\end{array}$ & $\sim 20$ & $\sim 20$ \\
\hline $\begin{array}{l}\text { Calico Hills } \\
\text { Formation (Th) }\end{array}$ & $\begin{array}{l}\text { Bedded Tuff: Ash-fall tuff; grayish-orange and pale- } \\
\text { yellowish-brown. Zeolitized; quartz-rich; minor lithic } \\
\text { fragments; minor biotite. }\end{array}$ & $60-120$ & 95 \\
\hline
\end{tabular}


Table 2-2

Lithologic Descriptions for Typical Tuff Pile Geologic Units (continued)

\begin{tabular}{|c|c|c|c|}
\hline $\begin{array}{l}\text { Stratigraphic Unit } \\
\text { (Map Symbol) }\end{array}$ & Lithologic Description & $\begin{array}{c}\text { Typical } \\
\text { Thickness } \\
\text { (feet) }\end{array}$ & $\begin{array}{c}\text { Average } \\
\text { Thickness } \\
\text { (feet) }\end{array}$ \\
\hline $\begin{array}{l}\text { tuff of Wahmonie } \\
\text { Flat (Twlb) }\end{array}$ & $\begin{array}{l}\text { Bedded Tuff: Ash-fall tuff; pale-greenish-yellow to } \\
\text { grayish-yellow and moderate-yellowish-brown. } \\
\text { Zeolitized; common pumice and phenocrysts; rare lithic } \\
\text { fragments. Phenocrysts include rare quartz, abundant } \\
\text { plagioclase and conspicuous biotite, and minor } \\
\text { hornblende, orthopyroxene, and olivine. }\end{array}$ & $0-115$ & 66 \\
\hline $\begin{array}{l}\text { Crater Flat Group, } \\
\text { undifferentiated } \\
\text { (Tc) }\end{array}$ & $\begin{array}{l}\text { Bedded Tuff: Reworked and ash-fall tuff; yellowish- } \\
\text { gray to moderate-yellowish-brown. Zeolitized; well } \\
\text { indurated; common very-pale orange pumice; common } \\
\text { quartz, biotite, hornblende, and pyroxene. Bedded } \\
\text { tuffs not differentiated. }\end{array}$ & $105-275$ & 205 \\
\hline $\begin{array}{l}\text { bedded Grouse } \\
\text { Canyon Tuff } \\
\text { (Tbgb) }\end{array}$ & $\begin{array}{l}\text { Bedded Tuff: Ash-fall tuff; peralkaline. Dusky-yellow } \\
\text { to light-olive-brown; zeolitized; abundant pumice; } \\
\text { phenocryst-poor, no biotite. Dendritic } \mathrm{MnO}_{2} \text { stains are } \\
\text { common. Ash-flow tuff lithofacies not present in Tuff } \\
\text { Pile area. }\end{array}$ & $0-60$ & 26 \\
\hline \multirow[t]{2}{*}{$\begin{array}{l}\text { Tunnel Formation, } \\
4 \text { Member (Tn4) }\end{array}$} & \multirow{2}{*}{$\begin{array}{l}\text { Bedded Tuff: Ash-fall, reworked tuff and minor ash- } \\
\text { flow tuff; yellowish-gray, moderate-yellowish-brown, } \\
\text { and very-pale-orange. Zeolitized; well indurated; some } \\
\text { peralkaline tuff beds present. Beds } 4 \text { E-equivalent is } \\
\text { a nonwelded to partially welded ash-flow tuff } \\
\text { characterized by the presence of very large } \\
(>3 \text { centimeters [cm]) lithic fragments and large pumice } \\
(>1 \mathrm{~cm}) \text {. Unit is zeolitic. Colors are grayish-yellow, } \\
\text { moderate-reddish-orange to moderate-orange-pink. }\end{array}$} & $\begin{array}{c}\text { Tn4 } \\
0-340\end{array}$ & 257 \\
\hline & & $\begin{array}{l}\text { Tn4E } \\
0-155\end{array}$ & 99 \\
\hline \multirow[t]{2}{*}{$\begin{array}{l}\text { Tunnel Formation, } \\
3 \text { Member (Tn3) }\end{array}$} & \multirow{2}{*}{$\begin{array}{l}\text { Bedded Tuff: Ash-fall tuff, reworked tuff, tuffaceous } \\
\text { sandstone, and minor ash-flow tuff. Moderate- } \\
\text { yellowish-orange to moderate-reddish-brown; } \\
\text { zeolitized; well indurated; massive; fine-grained unit at } \\
\text { top. Alternating ash-fall and reworked tuffs that are } \\
\text { grayish-orange-pink, moderate-reddish-orange, and } \\
\text { grayish-yellow; with minor phenocrysts of quartz and } \\
\text { feldspar; rare to minor biotite; minor lithic fragments; } \\
\text { locally bleached zones. Beds 3BC-equivalent is } \\
\text { nonwelded to partially welded ash-flow tuff and bedded } \\
\text { tuff; grayish-orange; phenocryst-poor, with common } \\
\text { shard clasts; zeolitic. }\end{array}$} & $\begin{array}{c}\text { Tn3 } \\
120-230\end{array}$ & 187 \\
\hline & & $\begin{array}{c}\text { Tn3BC } \\
55-80\end{array}$ & 75 \\
\hline $\begin{array}{l}\text { Tub Spring Tuff } \\
\text { (Tub) }\end{array}$ & $\begin{array}{l}\text { Ash-Fall Tuff: Moderate-greenish-yellow to yellowish- } \\
\text { gray. Peralkaline, zeolitic. Wavy, moderate-reddish- } \\
\text { brown paleosols } 1 \text { to } 3 \text { millimeters thick may be } \\
\text { present. Minor quartz phenocrysts. Ash-flow tuff } \\
\text { lithofacies not present in Tuff Pile area. }\end{array}$ & $0-50$ & 16 \\
\hline
\end{tabular}


Table 2-2

Lithologic Descriptions for Typical Tuff Pile Geologic Units (continued)

\begin{tabular}{|c|c|c|c|}
\hline $\begin{array}{l}\text { Stratigraphic Unit } \\
\text { (Map Symbol) }\end{array}$ & Lithologic Description & $\begin{array}{c}\text { Typical } \\
\text { Thickness } \\
\text { (feet) } \\
\end{array}$ & $\begin{array}{c}\text { Average } \\
\text { Thickness } \\
\text { (feet) }\end{array}$ \\
\hline $\begin{array}{l}\text { Tunnel bed } 2 \\
\text { (Ton2) }\end{array}$ & $\begin{array}{l}\text { Bedded Tuff: Ash-fall tuff, reworked ash-fall tuff, } \\
\text { interspersed with thin beds of tuffaceous sandstone. } \\
\text { Pale-reddish-brown, moderate-orange-pink, and } \\
\text { pale-greenish yellow; zeolitized; numerous pisolites } \\
\text { present within the tuffaceous sandstone layers. Thin } \\
\text { layers of greenish, peralkaline ash-fall tuff give the unit } \\
\text { a colorful, banded appearance. Common to abundant } \\
\text { pumice; minor feldspar and quartz phenocrysts and } \\
\text { minor biotite. }\end{array}$ & $40-160$ & 107 \\
\hline $\begin{array}{l}\text { Yucca Flat Tuff } \\
\text { (Toy) }\end{array}$ & $\begin{array}{l}\text { Ash-Flow Tuff: Nonwelded to partially welded; } \\
\text { yellowish-gray, pale-reddish-brown, and moderate- } \\
\text { reddish-brown; devitrified to zeolitic; common pale- } \\
\text { greenish-yellow to white pumice, up to } 4 \mathrm{~cm} \text { in size } \\
\text { with biotite inclusions; phenocrysts include common } \\
\text { plagioclase, sanidine, and lesser quartz; minor lithic } \\
\text { fragments up to } 1 \mathrm{~cm} \text { in size. }\end{array}$ & $0-105$ & 61 \\
\hline $\begin{array}{l}\text { Tunnel bed } 1 \\
\text { (Ton1) }\end{array}$ & $\begin{array}{l}\text { Bedded Tuff: Thick-bedded ash-fall tuffs, alternating } \\
\text { with thin beds of ash-fall and reworked ash-fall tuff. } \\
\text { Reddish-purple, reddish-brown to brick-red; zeolitic to } \\
\text { argillic; unit has a banded appearance. }\end{array}$ & $?(<100)$ & -- \\
\hline $\begin{array}{l}\text { Redrock Valley } \\
\text { Tuff (Tor) }\end{array}$ & $\begin{array}{l}\text { Ash-Flow Tuff: Nonwelded to partially welded; pastel } \\
\text { colors from pale-reddish-brown to grayish orange; } \\
\text { devitrified, also argillized and zeolitized in parts. } \\
\text { Phenocrysts include rare quartz, common plagioclase, } \\
\text { sanidine, and biotite; with minor hornblende. }\end{array}$ & 45 & 45 \\
\hline $\begin{array}{l}\text { older tuffs, } \\
\text { undifferentiated } \\
\text { (To2) } \\
\text { (informal unit) }\end{array}$ & $\begin{array}{l}\text { Bedded Tuff: Ash-fall and reworked tuff; typically } \\
\text { strongly zeolitic to argillic; pale-reddish-brown, light- } \\
\text { brown, pale to moderate-greenish-yellow, and grayish- } \\
\text { red; minor pumice; minor quartz and feldspar crystals; } \\
\text { rare to minor mafic minerals; lithic fragments } \\
\text { composed of volcanic and Paleozoic rocks. }\end{array}$ & 90 & 90 \\
\hline $\begin{array}{l}\text { tuff of Twin Peaks } \\
\text { (Tot) }\end{array}$ & $\begin{array}{l}\text { Ash-Flow Tuff: Nonwelded to partially welded; light- } \\
\text { gray to medium brown; devitrified to zeolitic; common } \\
\text { pumice and felsic crystals; rare biotite, sparse } \\
\text { hornblende, rare clinopyroxene and sphene. Lithic-rich } \\
\text { with fragments of lava flows, gneiss, schist, granite, } \\
\text { and sedimentary rocks. }\end{array}$ & $0-170$ & 107 \\
\hline $\begin{array}{l}\text { older tuffs, } \\
\text { undifferentiated } \\
\text { (To1) } \\
\text { (informal unit) }\end{array}$ & Similar to To2 & $0-280$ & 168 \\
\hline
\end{tabular}


Table 2-2

Lithologic Descriptions for Typical Tuff Pile Geologic Units (continued)

\begin{tabular}{||l|l|c|c||}
\hline \hline $\begin{array}{c}\text { Stratigraphic Unit } \\
\text { (Map Symbol) }\end{array}$ & \multicolumn{1}{|c|}{ Lithologic Description } & $\begin{array}{c}\text { Typical } \\
\text { Thickness } \\
\text { (feet) }\end{array}$ & $\begin{array}{c}\text { Average } \\
\text { Thickness } \\
\text { (feet) }\end{array}$ \\
\hline \hline $\begin{array}{l}\text { Paleocolluvium } \\
\text { (TIc) }\end{array}$ & $\begin{array}{l}\text { Paleocolluvium: Moderate to dark reddish-brown; } \\
\text { consists of angular blocks of Paleozoic-age carbonate } \\
\text { and clastic rocks in an argillic matrix. Upper part } \\
\text { typically is tuffaceous. }\end{array}$ & $8-120$ & 36 \\
\hline $\begin{array}{l}\text { Paleozoic rocks, } \\
\text { undifferentiated }\end{array}$ & $\begin{array}{l}\text { Cambrian to Devonian Carbonate: Rocks are mostly } \\
\text { limestone and dolomite, with interbedded siltstone and } \\
\text { sandstone. }\end{array}$ & $\sim 8,800$ & $\sim 8,800$ \\
\hline
\end{tabular}

a Detailed lithologic descriptions for specific boreholes are included in Cavazos et al. (1987), Davies et al. (1982), Drellack et al. (1983; 1986), and Prothro et al. (1999).

\subsection{Geologic Cross Sections}

Figure 2-2 shows the location of drill holes in the Tuff Pile area. Also plotted on Figure 2-2 are the locations of four detailed geologic cross sections that illustrate the sub-surface geology throughout the Tuff Pile area. One cross section transects the Tuff Pile from north to south, and three are west-to-east sections across the northern, central, and southern parts of the Tuff Pile. The north-south geologic cross section (Figure 2-3) is parallel to structure and shows the consistency of the geologic units in the Tuff Pile structural block. The west-to-east cross sections (Figures 1-4 [presented in Section 1.0], 2-4, and 2-5) are normal to structure and delineate the west-dipping Tuff Pile structural block between the east-dipping Yucca and Topgallant faults. These sections also illustrate the approximate 15-degree westward dip of the beds.

\subsection{Hydrologic Setting}

The rocks of the NTS have been classified hydrologically using a two-level classification scheme that includes HGUs and HSUs (International Technologies Corporation [IT], 1996a, 1996b; BN, 2002, 2005, 2006; National Security Technologies, LLC, 2007; Prothro et al., 2009). HGUs categorize rocks according to their ability to transmit groundwater (i.e., aquifers [transmit water] or confining units [do not readily transmit water]). A rock unit's ability to transmit ground water is mainly a function of the rock's primary lithologic properties, degree of fracturing, and secondary mineral alteration. HSUs are larger, more regional mapping units that group contiguous stratigraphic intervals that have similar hydrogeologic characteristics (i.e., composed of similar HGUs). 


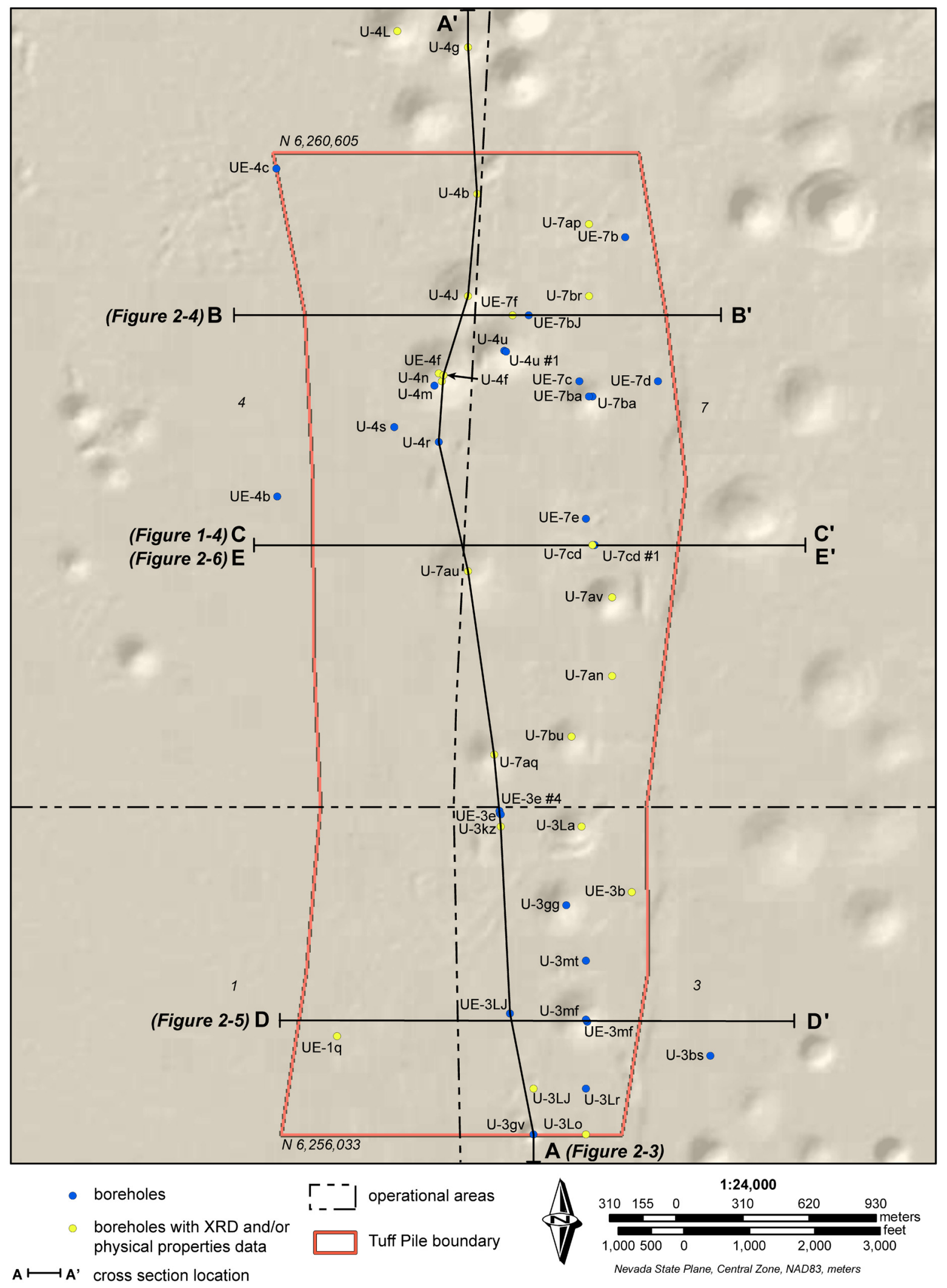

Figure 2-2

Locations of Boreholes and Cross Section Transects in the Area of the Tuff Pile 


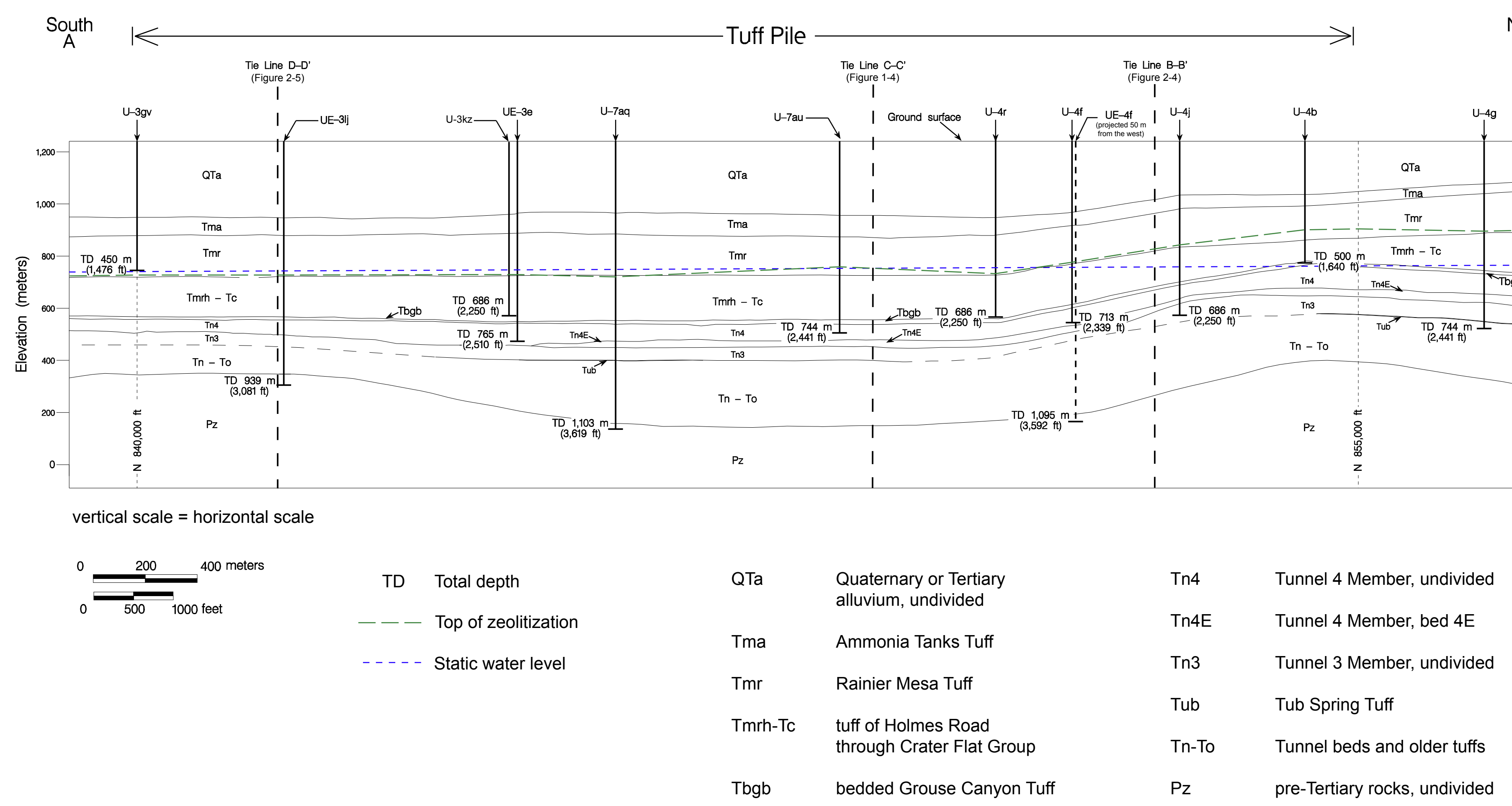

Cross section location shown on Figure 2-2 


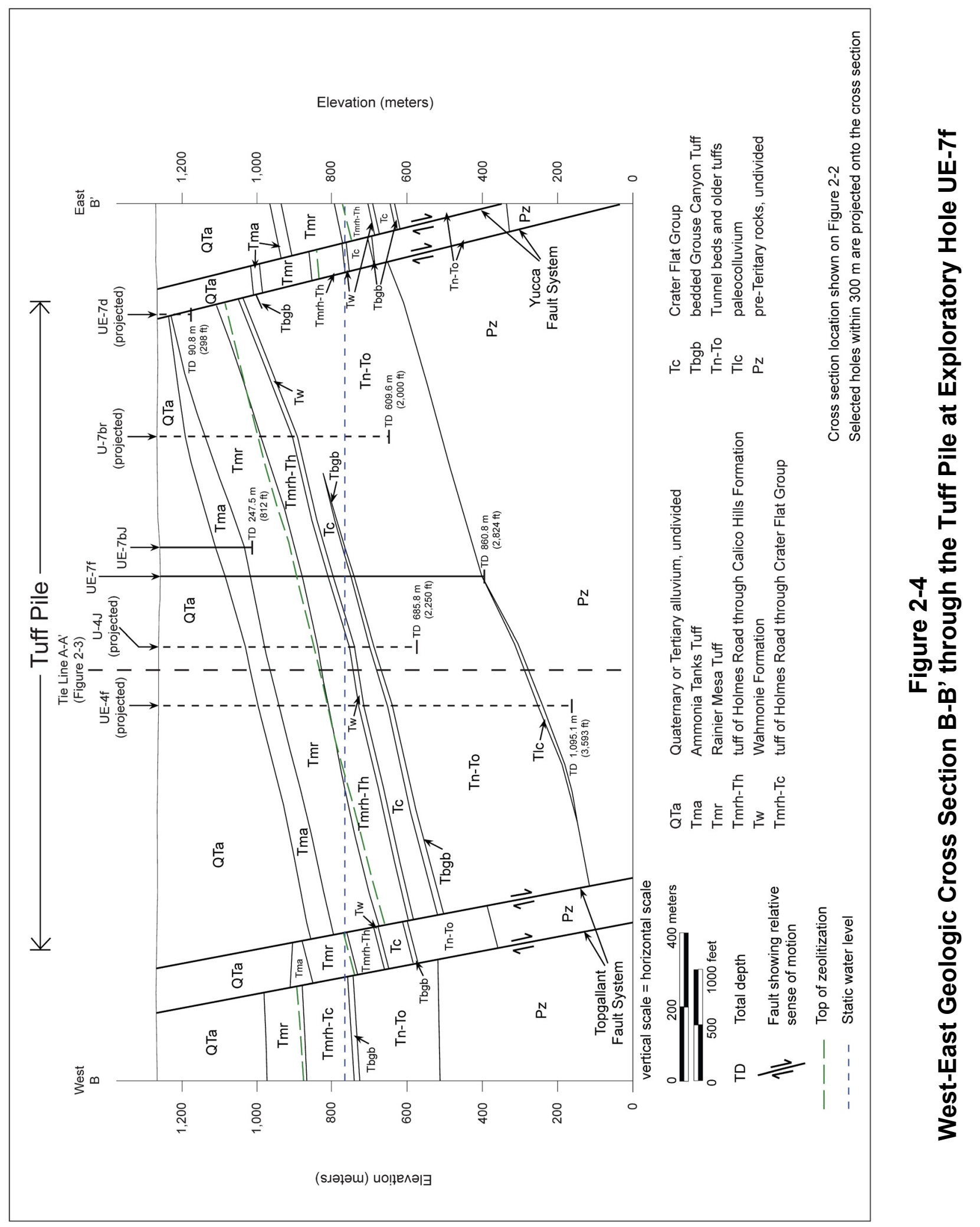




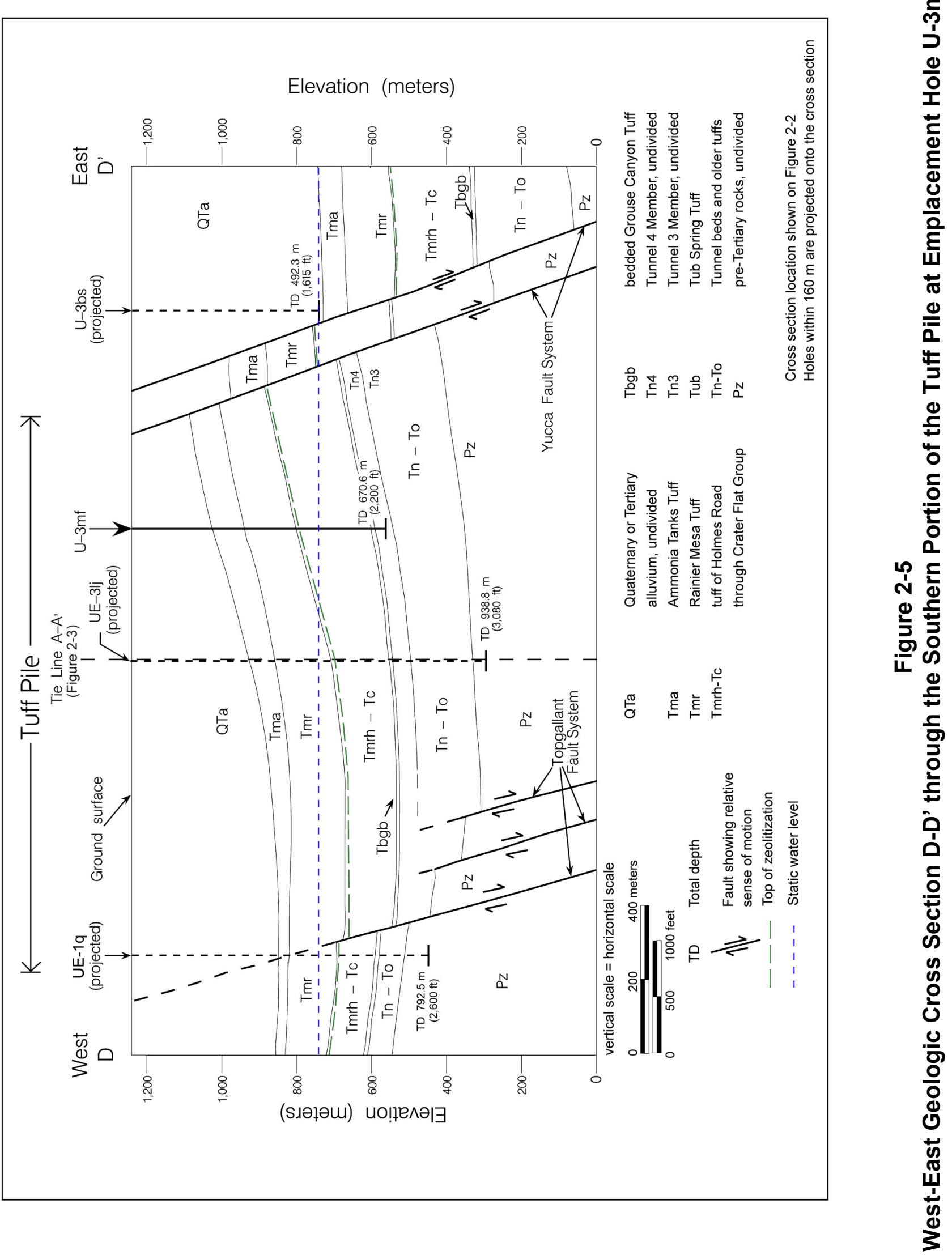




\subsubsection{Hydrogeology}

The rocks of the Tuff Pile area are divided into six HGUs, which are briefly described in Table 2-3. The five most important HGUs are illustrated on the hydrogeologic cross section presented in Figure 2-6, but the section does not extend deep enough to show the lowest HGU, the clastic confining unit (CCU).

The volcanic rocks in UGTA HFMs are categorized into four HGUs. In general, the altered volcanic rocks, which are typically zeolitized and support few fractures, as described above, act as confining units, and the unaltered rocks form aquifers. The aquifer units are further divided into WTAs, vitric-tuff aquifers (VTAs) (depending on degree of welding), and lava-flow aquifers (not present in the Tuff Pile area). Welded ash-flow tuffs and lava flows typically contain naturally occurring cooling joints, and, due to their higher density, they tend to fracture readily. Therefore, these rocks have relatively high fracture permeability (Blankennagel and Weir, 1973; Winograd and Thordarson, 1975; Laczniak et al., 1996; IT, 1996b; Prothro and Drellack, 1997). See Section 3.0 for a discussion of the physical characteristics that typify these units. See Section 4.0 for detailed information on the volcanic HSUs of the Tuff Pile area.

\subsubsection{Water Levels}

The static water level (SWL) in the Yucca Flat basin is relatively deep. Water levels in wells open to volcanic units in the Tuff Pile area range from about 470 to $506 \mathrm{~m}(1,550$ to $1,660 \mathrm{ft}$ ) depth, or 759 to $785 \mathrm{~m}$ (2,460 to 2,575 ft) above sea level (Doty and Thordarson, 1983; Hale et al., 1995). In the Tuff Pile area, the SWL is located within the volcanic section (Figure 1-4). Elevation of the water table for the LCA in the Yucca Flat area is about $730 \mathrm{~m}(2,400 \mathrm{ft})$ above mean sea level (Laczniak et al., 1996; Hale et al., 1995).

Fluid levels measured in wells completed in the alluvial aquifer (AA) and volcanic units in the eastern two-thirds of Yucca Flat are typically about $20 \mathrm{~m}$ (70 ft) higher than in wells completed in the regional carbonate aquifer (Winograd and Thordarson, 1975; IT, 1996b; Fenelon, 2005). The hydrogeology of these units suggests that the higher elevation of the water table in the overlying Tertiary rocks is related to the presence of low-permeability, zeolitized tuffs of the TCU (aquitard) between the Paleozoic and Tertiary aquifers. Detailed water-level data indicate the existence of a groundwater trough along the axis of the valley. The semi-perched water within the alluvium and volcanic aquifers eventually moves downward to the carbonate aquifer in the central portion of the valley, perhaps facilitated by the basin-forming faults (Yucca and Topgallant faults). 


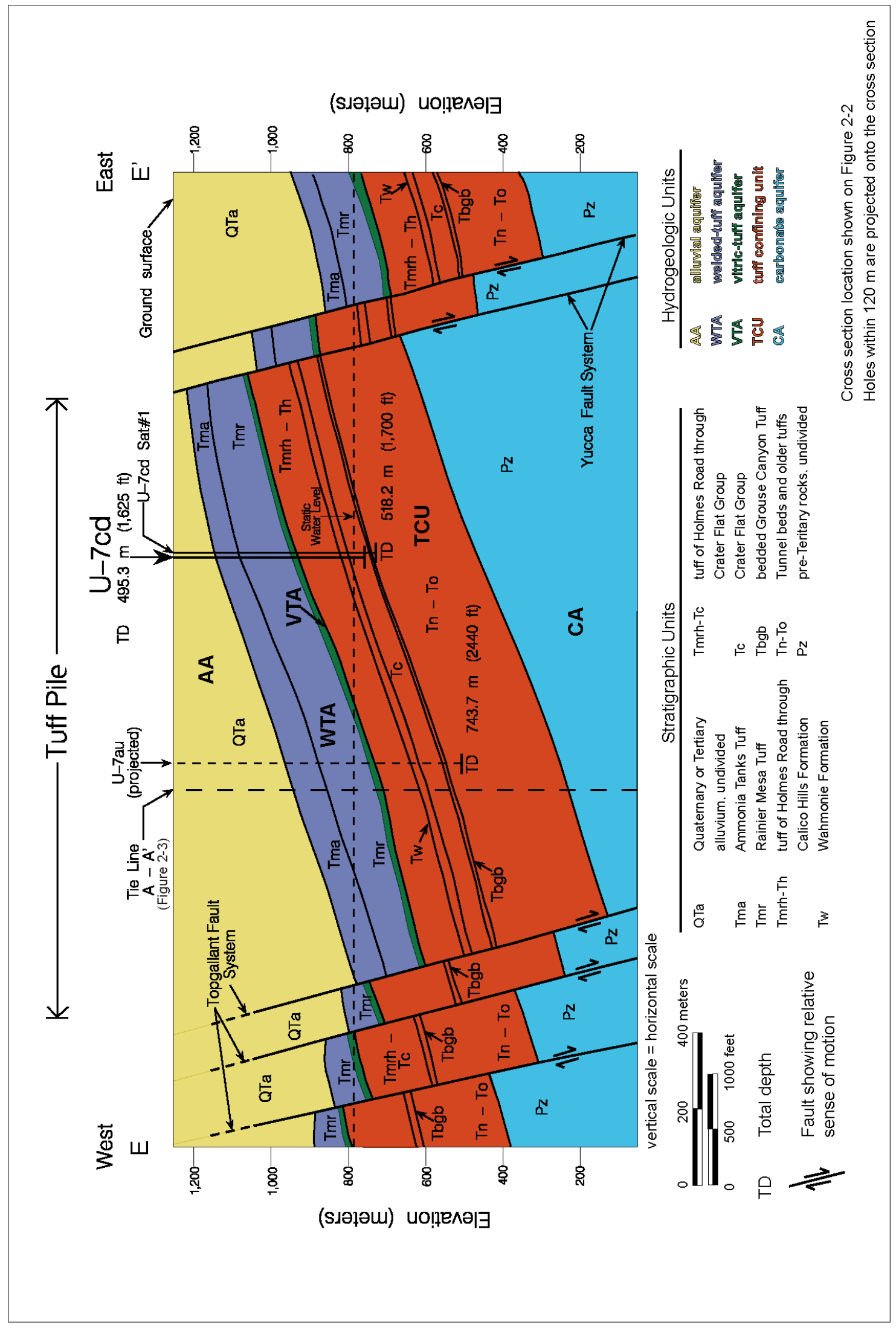

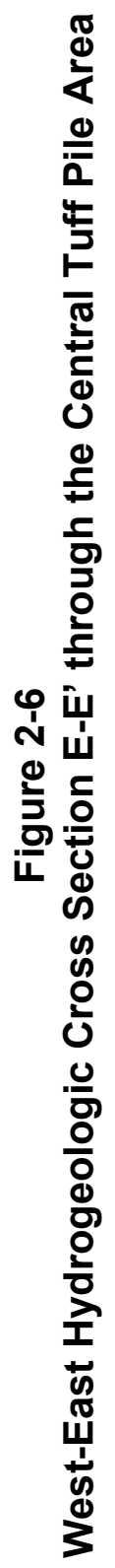


Table 2-3

Hydrogeologic Units of the Tuff Pile Area

(Adapted from BN, 2006)

\begin{tabular}{|c|c|c|}
\hline Hydrogeologic Unit & Typical Lithologies & Hydrologic Significance \\
\hline $\begin{array}{l}\text { Alluvial aquifer } \\
\text { (AA) } \\
\text { (AA is also an HSU } \\
\text { in the Yucca Flat } \\
\text { hydrogeologic model) }\end{array}$ & $\begin{array}{l}\text { Unconsolidated to partially } \\
\text { consolidated gravelly sand, } \\
\text { eolian sand, and colluvium }\end{array}$ & $\begin{array}{l}\text { Has characteristics of a highly conductive } \\
\text { aquifer, but less so where lenses of clay-rich } \\
\text { paleocolluvium, zeolitic alteration, or playa } \\
\text { deposits are present. }\end{array}$ \\
\hline $\begin{array}{l}\text { Welded-tuff aquifer } \\
\text { (WTA) }\end{array}$ & $\begin{array}{l}\text { Welded ash-flow tuff; vitric } \\
\text { to devitrified }\end{array}$ & $\begin{array}{l}\text { Degree of welding greatly affects interstitial } \\
\text { porosity (i.e., porosity decreases as degree of } \\
\text { welding increases) and permeability (i.e., } \\
\text { fracture permeability increases as degree of } \\
\text { welding increases). }\end{array}$ \\
\hline $\begin{array}{l}\text { Vitric-tuff aquifer } \\
\text { (VTA) }\end{array}$ & $\begin{array}{l}\text { Nonwelded ash-flow tuff, } \\
\text { bedded tuff; ash-fall and } \\
\text { reworked tuff; vitric }\end{array}$ & $\begin{array}{l}\text { Constitutes a volumetrically minor HGU. } \\
\text { Generally does not extend far below the SWL } \\
\text { due to tendency of (glassy/vitric) tuffs to } \\
\text { become zeolitic under saturated conditions, } \\
\text { which drastically reduces permeability. } \\
\text { Significant interstitial porosity (i.e., } 20 \text { to } \\
40 \text { percent). Generally insignificant fracture } \\
\text { permeability. }\end{array}$ \\
\hline $\begin{array}{l}\text { Tuff confining unit } \\
\text { (TCU) }\end{array}$ & $\begin{array}{l}\text { Zeolitic bedded tuff with } \\
\text { interbedded, but less } \\
\text { significant, zeolitic, } \\
\text { devitrified nonwelded to } \\
\text { partially welded ash-flow } \\
\text { tuff }\end{array}$ & $\begin{array}{l}\text { May be saturated but measured } \\
\text { transmissivities are very low. May cause semi- } \\
\text { perched conditions. }\end{array}$ \\
\hline $\begin{array}{l}\text { Carbonate aquifer } \\
\text { (CA) }\end{array}$ & Dolomite, limestone & $\begin{array}{l}\text { Transmissivity values differ greatly and are } \\
\text { directly dependent on fracture frequency. }\end{array}$ \\
\hline $\begin{array}{l}\text { Clastic confining unit } \\
(\mathrm{CCU})\end{array}$ & Argillite, siltstone, quartzite & $\begin{array}{l}\text { Siliciclastic rocks are relatively impermeable; } \\
\text { coarser-grained siliciclastic rocks are fractured, } \\
\text { but with fracture porosity generally sealed due } \\
\text { to secondary mineralization. }\end{array}$ \\
\hline
\end{tabular}

Existing data and interpretations from the regional groundwater flow model (DOE/NV, 1997) indicate that the overall groundwater flow direction in the Yucca Flat area is to the south and southwest. Groundwater ultimately discharges at Ash Meadows and Alkali Flat (Franklin Lake) to the south and Death Valley to the southwest (Laczniak et al., 1996).

Anomalously high potentiometric head measurements noted in parts of central Yucca Flat, especially in the Tuff Pile area, are related to over-pressurization of the saturated zeolitized tuffs, 
resulting in elevated potentiometric surfaces with increasing depth (Hawkins et al., 1988; 1989; Hale, 1995; Halford et al., 2005). This phenomenon is believed to be caused by UGTs that were conducted in this area. The pressure is dissipating very slowly, reflecting the low conductivity of the zeolitized tuffs (Wohletz et al., 1999). These highly zeolitized rocks are described as having high porosity and low permeability (Winograd and Thordarson, 1975). The low permeability of the bedded tuffs is evidenced by the slow rise of water levels in response to nuclear testing. Water levels measured in wells open to zeolitic, bedded tuff units typically take months to years to reach equilibrium after drilling (Halford et al., 2005). Water levels in wells drilled into or through saturated fractured, conductive units (i.e., WTAs) equilibrate quickly. See Section 3.0 for more information about these low permeability rocks. 


\subsection{Physical Characteristics of the Tuff Pile}

A variety of techniques were used to characterize UGT sites for the WTP, including mineralogical analyses, physical properties measured on samples, and borehole geophysical logs. These data are also important in determining the hydrologic characteristics of tuffs and assignment of HGUs. To define HSUs for the UGTA HFM, stratigraphic position (described in Section 2.0) and identification of HGUs are both considered, as described in Section 4.0. This section presents the data used to determine HGUs for the volcanic rocks at the NTS.

Figure 2-2 shows the distribution of boreholes in the Tuff Pile area for which physical properties and/or mineralogical data are available, which were used in preparation of this section. These holes are listed in Table 3-1.

\subsection{Mineralogic Characteristics of Volcanic Rocks}

Most of the volcanic rocks in the vicinity of Yucca Flat are pyroclastic rocks composed of ash-flow tuff and ash-fall deposits of generally rhyolitic composition. These silica-rich rocks can be composed of more than 80 percent glass when originally deposited (the remainder is a mixture of original phenocrysts and lithic fragments). Alteration and diagenetic minerals, such as zeolite, clay, and carbonate, are initially rare in these vitric rocks. Post-depositional processes such as welding, devitrification, zeolitization, and argillization, however, can significantly alter not only the hydraulic properties but also the mineralogy of volcanic rocks. On average, volcanic units in the Southwestern Nevada Volcanic Field show fairly consistent mineralogy that tends to vary only as a function of style and intensity of alteration (Warren et al., 2003).

\subsubsection{Alteration}

Devitrification, which is typically associated with welded ash-flow tuffs and the interior portions of lava flows, occurs during cooling of ash-flow tuffs and lavas shortly after emplacement. This post-depositional process results in the conversion of the original glass to micro-crystalline quartz and feldspar and, thus, yields a rock composed almost entirely of non-reactive quartz and feldspar that is resistant to other post-depositional processes such as zeolitization and argillization. Devitrified, welded ash-flow tuffs form important aquifers beneath Yucca Flat (e.g., the Timber Mountain and Topopah Spring WTA HSUs).

Volcanic rocks that remain vitric after deposition, such as nonwelded ash-flow tuffs, ash-fall deposits, and the pumiceous portions of lavas, are susceptible to diagenetic alteration processes. 
Table 3-1

Holes in the Tuff Pile Area with Physical Properties and/or Mineralogical Data

\begin{tabular}{|c|c|c|}
\hline Tuff Pile Drill Holes & $\begin{array}{c}\text { Physical Properties } \\
\text { Data Available } \\
\end{array}$ & $\begin{array}{c}\text { Mineralogical Data } \\
\text { Available }\end{array}$ \\
\hline UE-1q & & $x$ \\
\hline UE-3b & $x$ & \\
\hline U-3kz & $x$ & \\
\hline U-3La & $x$ & $x$ \\
\hline U-3Lj & $x$ & \\
\hline U-3Lo & $x$ & \\
\hline U-4b & & $x$ \\
\hline U-4f & $x$ & \\
\hline UE-4f & $x$ & \\
\hline U-4g & $x$ & \\
\hline U-4j & $x$ & \\
\hline U-4L & $x$ & \\
\hline U-4n & $x$ & \\
\hline UE-7f & & $x$ \\
\hline U-7an & $x$ & \\
\hline U-7ap & $x$ & $x$ \\
\hline U-7aq & $x$ & $x$ \\
\hline U-7au & $x$ & $x$ \\
\hline U-7av & $x$ & $x$ \\
\hline U-7br & $x$ & \\
\hline U-7bu & $x$ & \\
\hline U-7cd & $x$ & \\
\hline
\end{tabular}


Zeolitization is common in volcanic rocks in the Yucca Flat area, and results in the original glass being converted to the zeolite mineral clinoptilolite, with lesser amounts of other zeolite minerals such as mordenite and analcime at deeper levels. Because of the high percentage of glass in the original rocks, zeolitization results in volcanic rocks composed predominantly of zeolite. Clay, mainly in the form of smectite, is usually a minor constituent. Large portions of the volcanic section beneath Yucca Flat are pervasively zeolitic and form important confining units.

Volcanic rocks are also susceptible to argillization. In this complex post-depositional process, portions of the original tuff deposits are converted to clay minerals such as smectite, illite, and lesser kaolinite (Dickerson et al., 2004). In the Yucca Flat area, the basal portion of the volcanic section is commonly pervasively argillic, and forms a confining unit that directly overlies the regional carbonate aquifer (see Section 4.2.3).

A large effort was undertaken to compile the available mineralogical data, mostly based on x-ray diffraction (XRD) analyses, for the YF-CM CAU (Stoller-Navarro Joint Venture [SNJV], 2007). The XRD data, along with a description of the compilation process, are presented in Appendix D of SNJV (2007) and are summarized here for the Tuff Pile area in Table 3-2. It is important to note that the sampling protocols in place for the WTP preferentially sampled the more altered horizons. Consequently, the dataset for these HSUs may be skewed toward higher clay values. Brief descriptions, including unit mineralogy, of selected HSUs in the Tuff Pile area are provided in the following sections.

\subsubsection{Mineralogy of Tuff Confining Units}

Altered volcanic rocks that compose the lower portion of the volcanic section beneath Yucca Flat form an important hydrogeologic layer because they separate the alluvial and volcanic aquifer units from the underlying regional LCA. Stratigraphically, these altered volcanic rocks may include all the Tertiary volcanic strata from the top of the Paleozoic rocks to the base of the welded portions of the Timber Mountain Tuff (i.e., base of the Timber Mountain welded-tuff aquifer [TM-WTA]). In Yucca Flat, these altered tuff units are subdivided into three TCU HSUs based on the relative abundances of major mineral assemblages (Prothro, 2005). These HSUs are (1) an upper zone characterized by the abundance of the zeolite mineral clinoptilolite with lesser amounts of felsic minerals and clay, designated LTCU; (2) a middle zone with felsic minerals greater than zeolites and much greater than clay, designated OSBCU; and (3) a basal argillic zone where clay is dominant over felsic minerals and clinoptilolite, designated the argillic tuff confining unit (ATCU). See Section 4.2 for more information about these HSUs in the Tuff Pile area. 
Table 3-2

Mineralogic Data for Geologic Units in the Tuff Pile Area

\begin{tabular}{|c|c|c|c|c|c|c|c|c|c|c|}
\hline \multirow[b]{2}{*}{$\begin{array}{c}\text { Stratigraphic } \\
\text { Unit }^{\text {a }}\end{array}$} & \multirow[b]{2}{*}{$\begin{array}{l}\text { Number of } \\
\text { Analyses }\end{array}$} & \multirow[b]{2}{*}{$\mathrm{HGU}^{\mathrm{c}}$} & \multirow[b]{2}{*}{ HSU $^{d}$} & \multicolumn{7}{|c|}{ 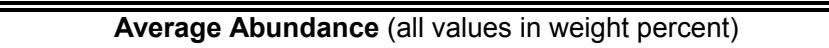 } \\
\hline & & & & Zeolite & $K A+S M$ & $\mathrm{CC}+\mathrm{DM}$ & GL & \begin{tabular}{|c|} 
Mafic \\
Minerals
\end{tabular} & QZ & FS \\
\hline QTa & 9 & AA & AA3, AA & 5.8 & 7.2 & 17.0 & 29.9 & 3.9 & 16.1 & 17.7 \\
\hline Tmab & 1 & $\mathrm{TCU}^{f}$ & TMUVTA & $40.0^{f}$ & $35.0^{f}$ & $\mathrm{~N} / \mathrm{A}$ & 7.0 & $\mathrm{~N} / \mathrm{A}$ & 7.0 & 10.0 \\
\hline Tmrr & 2 & WTA & TMWTA & 7.5 & 17.5 & 0 & 61.9 & 5.8 & 4.2 & 33.7 \\
\hline Tmrp & 6 & VTA, WTA & TMWTA, TMLVTA & $22.0^{g}$ & 0 & 0 & 18.5 & 0.6 & 7.4 & 67.1 \\
\hline Tmrb & 1 & TCU, VTA & TMLVTA & 2.5 & 20.0 & $\mathrm{~N} / \mathrm{A}$ & 30.0 & 2.5 & 7.0 & 20.0 \\
\hline Tmrh & 3 & TCU & LTCU & 64.5 & 5.8 & 4.8 & 0 & 1.1 & 5.3 & 21.2 \\
\hline Tpcp & 1 & TCU & LTCU & 66.7 & 2.2 & 0 & $\mathrm{~N} / \mathrm{A}$ & 1.5 & 1.7 & 14.6 \\
\hline Thr & 1 & TCU & LTCU & 73.0 & 5.5 & 0 & 0 & 0 & 5.5 & 5.5 \\
\hline Twlb & 12 & TCU & LTCU & 37.5 & 7.4 & 5.0 & 7.5 & 12.3 & 8.0 & 30.4 \\
\hline Tc & 12 & TCU & LTCU & 45.4 & 6.7 & 2.5 & 8.2 & 5.1 & 15.2 & 25.0 \\
\hline $\mathrm{Tcb}$ & 3 & TCU & LTCU & 61.9 & 11.7 & 0 & 0 & 0.6 & 3.0 & 13.9 \\
\hline Tbgb & 8 & TCU & LTCU & 59.7 & 5.9 & 2.5 & 7.0 & 5.0 & 5.0 & 27.4 \\
\hline $\operatorname{Tn} 4^{\mathrm{h}}$ & 9 & TCU & LTCU & 58.9 & 5.0 & $\mathrm{~N} / \mathrm{A}$ & 2.5 & 5.0 & 6.3 & 23.3 \\
\hline Tn4K & 2 & TCU & LTCU & 50.0 & 9.5 & $\mathrm{~N} / \mathrm{A}$ & 6.3 & 5.0 & 2.5 & 20.0 \\
\hline Tn4JK & 4 & TCU & LTCU & 48.6 & 11.7 & 0 & 0 & 2.2 & 7.2 & 25.0 \\
\hline Tn4J & 1 & TCU & LTCU & 37.5 & 17.5 & 0 & 0 & 0 & 5.5 & 17.5 \\
\hline $\mathrm{Tn} 4 \mathrm{H}$ & 5 & TCU & LTCU & 51.0 & 10.4 & $\mathrm{~N} / \mathrm{A}$ & 7.3 & 5.0 & 4.3 & 18.4 \\
\hline Tn4GH & 4 & TCU & LTCU & 46.0 & 3.4 & 0 & 0 & 0.7 & 6.6 & 29.5 \\
\hline Tn4G & 1 & TCU & LTCU & 60.0 & 5.0 & $\mathrm{~N} / \mathrm{A}$ & 7.0 & 2.5 & 2.5 & 15.0 \\
\hline Tn4E & 7 & TCU & LTCU & 48.1 & 2.5 & 2.5 & 3.8 & 2.5 & 5.5 & 19.3 \\
\hline Tn4AF & 3 & TCU & LTCU & 46.6 & 7.5 & 0 & 0 & 0 & 15.0 & 24.0 \\
\hline Tn3A & 1 & TCU & LTCU & 34.9 & 2.9 & 0 & $N / A$ & 3.9 & 15.9 & 37.1 \\
\hline Tub & 1 & TCU & LTCU & 46.4 & 19.6 & 0 & $N / A$ & 0 & 8.6 & 11.8 \\
\hline Toh & 2 & TCU & OSBCU, ATCU & 0 & 43.8 & 0 & 0 & 0 & 50.0 & 15.0 \\
\hline Ton2 & 9 & TCU & OSBCU & 50.7 & 5.1 & 0 & 0 & 1.0 & 14.7 & 30.5 \\
\hline Toy & 7 & TCU & OSBCU & 35.7 & 6.2 & 0 & 0 & 7.5 & 23.9 & 28.6 \\
\hline Ton1 & 2 & TCU & OSBCU & 28.6 & 12.5 & 0 & 0 & 1.6 & 33.3 & 36.3 \\
\hline Toru & 2 & TCU & OSBCU & 32.5 & 0 & 0 & 0 & 0 & 27.5 & 27.5 \\
\hline Tor & 9 & TCU & OSBCU & 25.5 & 14.1 & 0 & 0 & 3.5 & 31.0 & 28.8 \\
\hline Toa & 4 & TCU & OSBCU & 20.1 & 13.5 & 0 & 0 & 0 & 50.0 & 11.5 \\
\hline Tow & 2 & TCU & ATCU & 0 & 75.8 & 0 & N/A & 1.3 & 13.1 & 11.6 \\
\hline TIt & 3 & TCU & ATCU & 0 & 18.3 & 26.7 & 0 & 1.7 & 36.7 & 7.5 \\
\hline $\mathrm{Pz}$ & 1 & $\mathrm{CA}$ & LCA & 0 & 0 & 88.8 & $\mathrm{~N} / \mathrm{A}$ & 0 & 15.8 & 0 \\
\hline
\end{tabular}

Source: Abstracted from SNJV, 2007 (only samples from boreholes located within the Tuff Pile area).

Notes: a Refer to Table 2-1 for explanation of stratigraphic units.

b Includes data from the eight Tuff Pile area boreholes listed on Table 3-1 as providing minerlogical data.

c Refer to Table 2-3 for explanation of HGUs.

d Refer to Figure 4-1 for explanation of HSUs.

e Includes biotite, hornblende, and other iron and/or magnesium rich minerals.

$\mathrm{f}$ Anomalous. The Tmab in the Tuff Pile area is typically vitric.

$\mathrm{g}$ The Tmrp is typically devitrified (welded) to vitric (nonwelded). However, in the deepest portion of the Tuff Pile half graben, the upper level of zeolitization may include this younger stratigraphic unit.

h Samples from Tn4, undifferentiated.
Abbreviations:
$C C=$ calcite
$Q Z=$ quartz
$\mathrm{DM}=$ dolomite
FS = feldspars (combined)
$\mathrm{GL}=$ glass
$\mathrm{KA}=$ kaolinite
$\mathrm{SM}=$ smectite clay $\mathrm{N} / \mathrm{A}=$ not analyzed 


\subsubsection{Fracture Mineralization in Tuff Confining Units}

Prothro (2008) conducted an analysis of fractures in core from altered volcanic rocks beneath Yucca Flat. Prothro (2008) noted that almost all natural fractures were coated or filled with some type of secondary mineral, with many fractures containing more than one type of secondary mineral. Typical fracture-filling and coating minerals include zeolite, metallic oxides, crystalline quartz and chalcedony, calcite, and clay. Prothro (2008) reported that zeolite was observed in 48 percent of the fractures examined, and metallic oxides were observed in 37 percent of the fractures. Of the metallic oxides, iron oxides appeared to be the most common, with manganese oxide being less common. Additional mineralogical and isotopic details for altered tuffs beneath Yucca Flat are available in Dickerson et al. (2004).

Based on these studies, it is assumed that most fractures that form in TCUs are likely filled with secondary minerals, thereby further reducing their ability to transmit groundwater.

\subsection{Physical Properties}

Physical properties, such as porosity and bulk density, reflect lithologic variations. Welded tuffs are typically dense and have low matrix porosity. Nonwelded tuffs are less dense and more porous. Physical properties, as determined by discrete sample analyses (in a laboratory) or recorded by geophysical logging tools can confirm or support lithologic characteristics, as determined visually during logging of core or drill cuttings.

Figures 3-1 and 3-2 are photographs of pairs of samples from Exploratory Hole UE-12t\#3 on Rainier Mesa, where the Grouse Canyon Tuff and Tub Spring Tuff both exhibit a densely welded section overlying a nonwelded section. The nonwelded portion of the Grouse Canyon Tuff in this area is vitric, while the nonwelded portion of the Tub Spring Tuff is zeolitized. However, the difference in physical character between the welded and nonwelded portions of both units is visually apparent (see also Section 4.3).

The most hydrologically important of the physical properties commonly determined for boreholes in the Tuff Pile area is matrix porosity. This is a calculated value derived from values of grain density, bulk density, and water content measured in the laboratory on samples from the boreholes, typically conventional cores or sidewall cores.

Porosity values for the zeolitized units within the Tuff Pile area average between 36 and 41 percent (App and Marusak, 1983; 1997). Calculated porosity values for the stratigraphic 


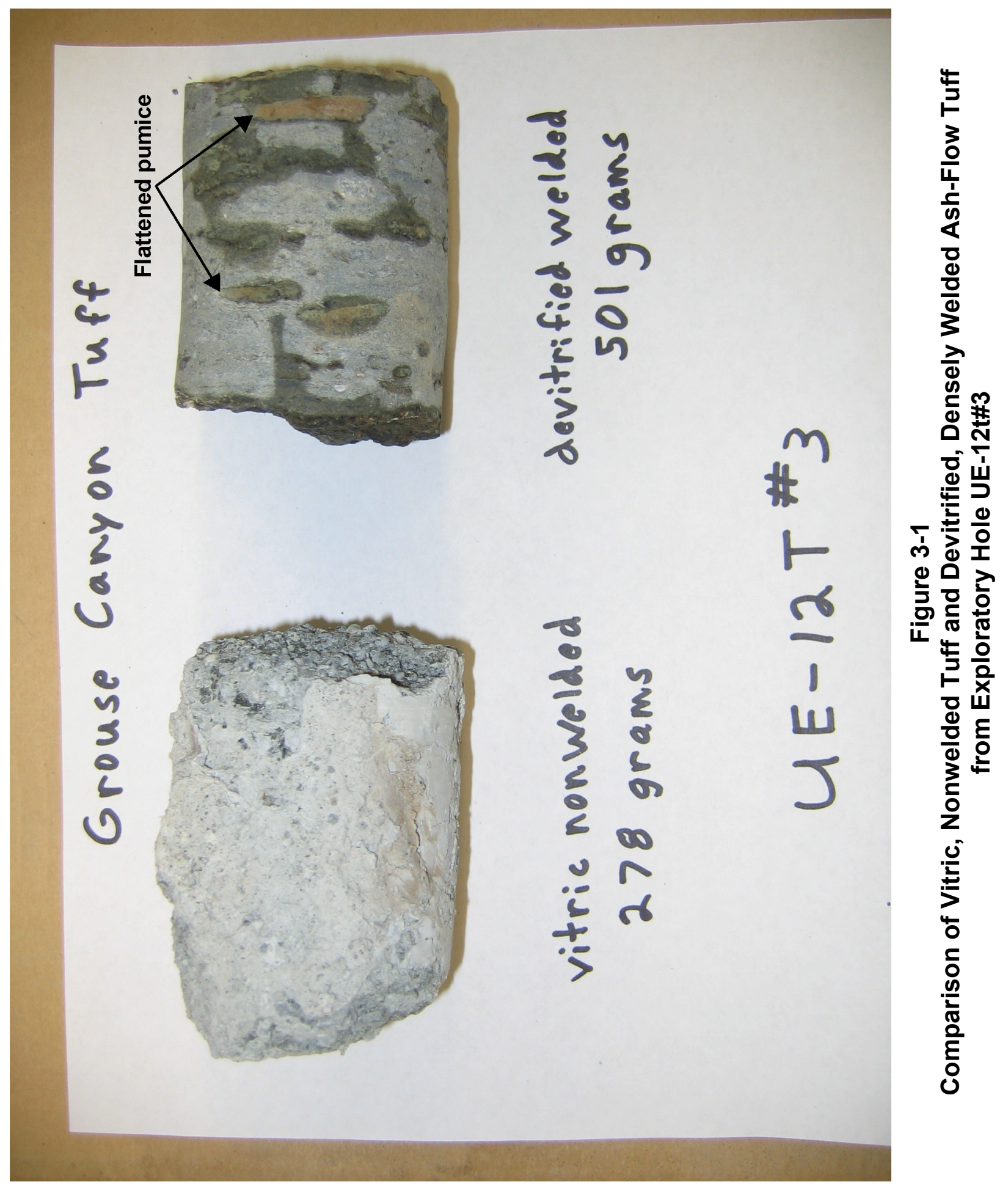




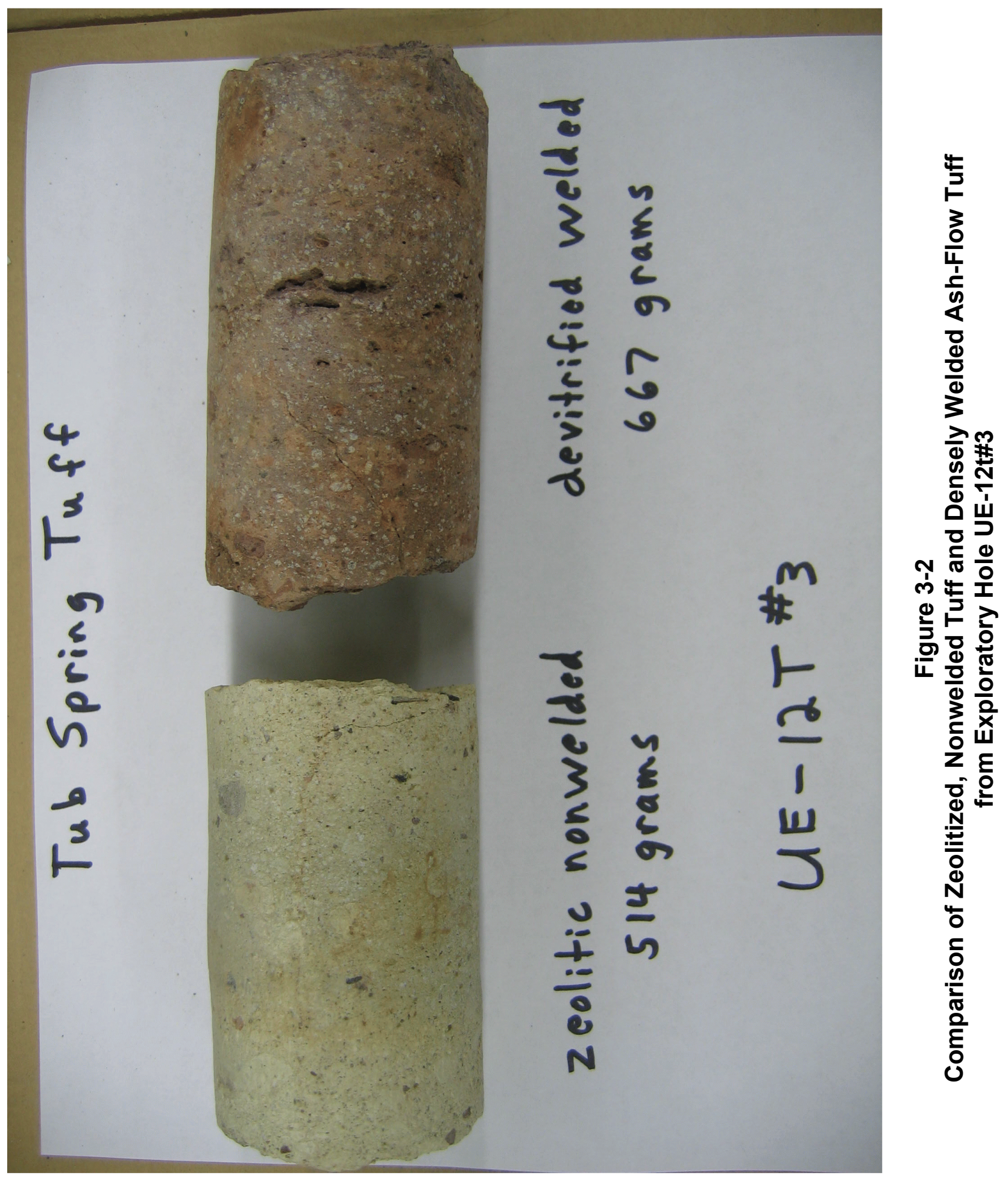


units below the level of zeolitization from ten boreholes in the Tuff Pile area extracted from the U.S. Geological Survey rock-property database found in Wood (2007) also average between 36 and 41 percent, as illustrated in the plot on Figure 3-3 (reflecting similar sources of data).

For comparison, Figure 3-3 also shows calculated porosity values for typical welded tuff units from Rainier Mesa (shown in red), as extracted from Wood (2007). The average porosity value for a typical Area 12 welded tuff, including data from the Rainier Mesa Tuff, Grouse Canyon Tuff, and Tub Spring Tuff, is 14 percent.

\subsection{Borehole Geophysical Logs}

Certain geological conditions evoke specific and predictable geophysical log responses and, thus, can be used to indirectly delineate lithology as well as physical properties of rocks. Geophysical logs give a nearly continuous sampling record of the rocks penetrated by the borehole (typically a measurement is recorded every 3 inches as the logging tool is pulled from the borehole). This record, combined with data from drill cuttings samples and data from nearby drill and core holes, significantly raises confidence in the resulting detailed lithologic characterizations.

This section describes the electric log and the caliper log responses to nonwelded and welded ash-flow tuff units; vitric vs. zeolitic ash-flow tuffs; and zeolitic vs. devitrified tuffs. Also presented are data that show the contrast between these units in the Tuff Pile area. We focus here on the best discriminator, the electric log, but a short description of the caliper log is also included.

Plate 1 shows resistivity logs, plotted with lithology and stratigraphy, for seven Tuff Pile area drill holes. The drill holes traverse the Tuff Pile area from north to south, as shown on the map in Figure 3-4. These plots are referred to throughout the following discussions.

\subsubsection{Caliper Log}

Caliper logging tools measure the diameter of an open borehole. This measurement is obtained by converting the mechanical movement of spring-loaded arms into electrical signals.

In addition to providing information on general borehole conditions, caliper log data are necessary for more accurate interpretation of other wireline geophysical logs. Most logging tools are influenced to some degree by borehole diameter, fluid, and/or mud cake thickness, but 

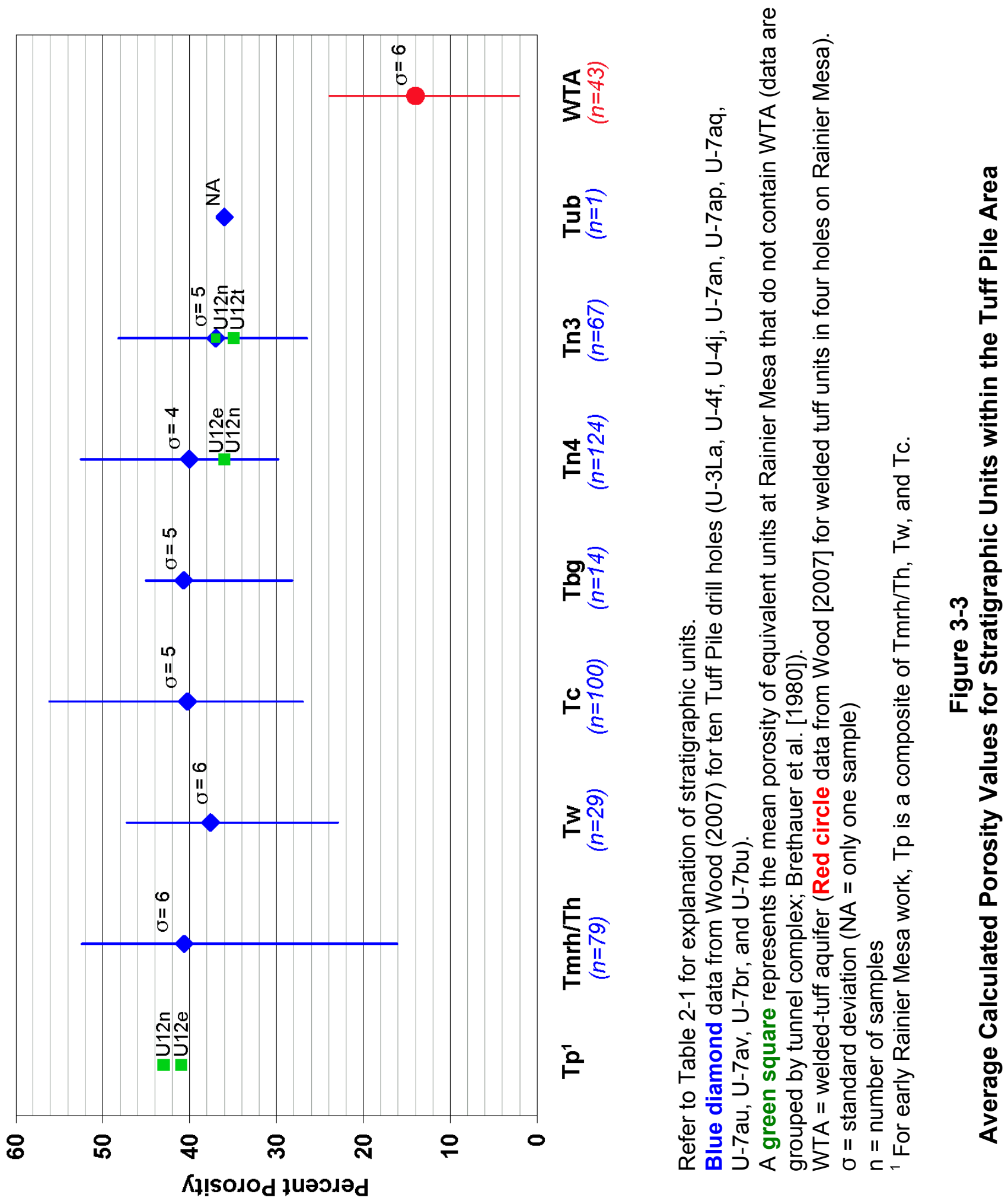


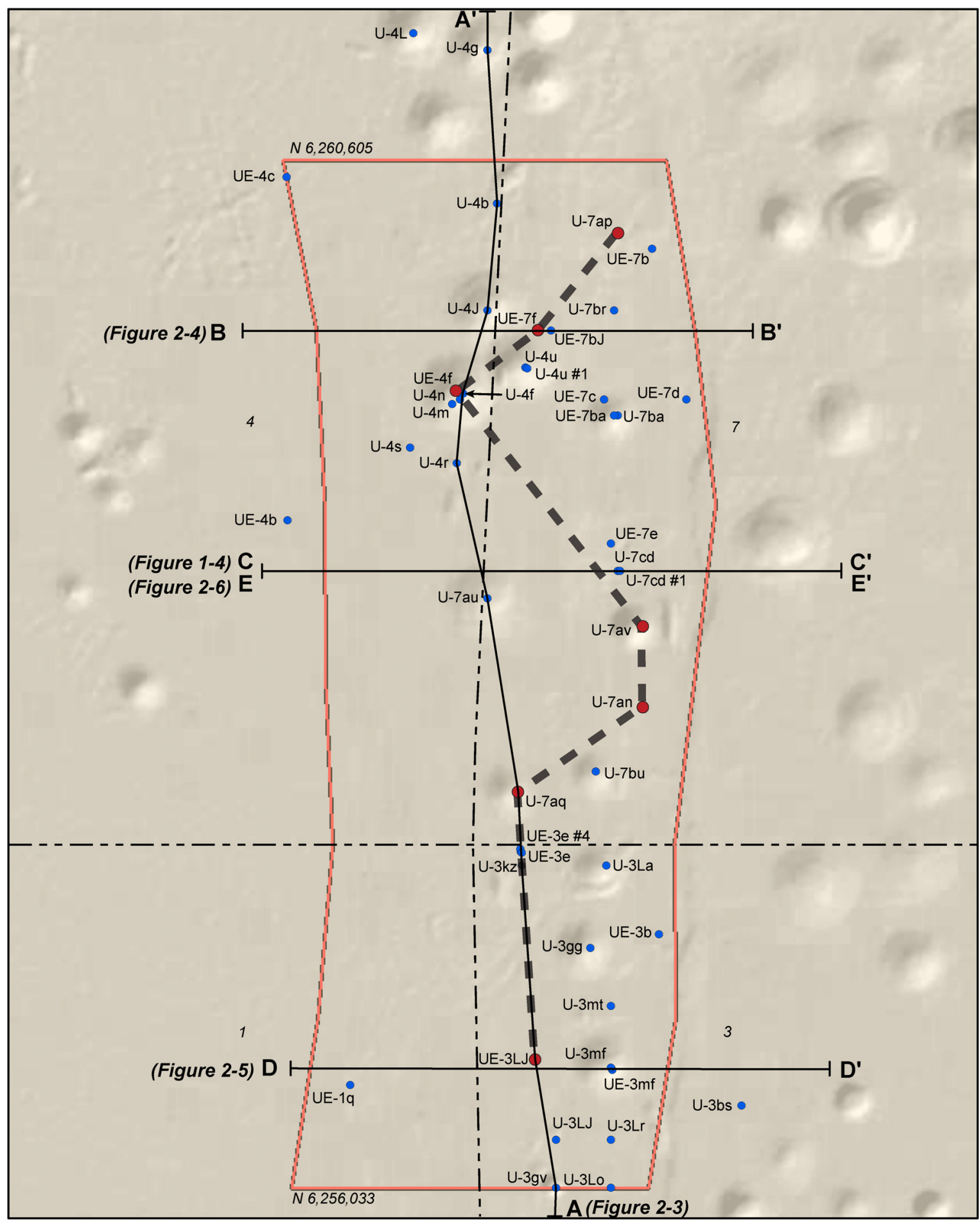

- boreholes

- boreholes used in Plate 1
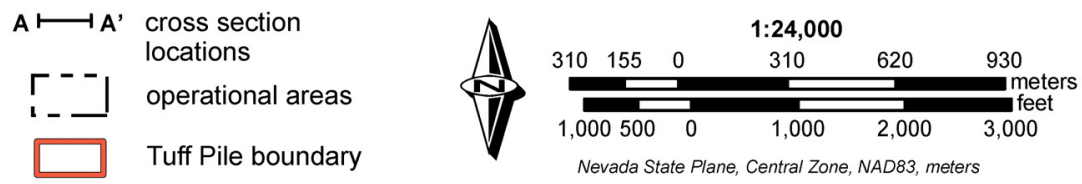

Figure 3-4

Location of Drill Holes from which Electric Logs are Presented in Plate 1 
caliper data may be used to compensate for the effect of some of these variables. In addition, proximity-dependent tools (pad type) can yield unreliable data in very rough or rugose holes, and the caliper log may indicate that these conditions exist. Because caliper log data serve many purposes, this log was run in all boreholes in the Tuff Pile, and numerous examples are available.

Most changes in hole size, as reflected by the caliper log, are caused by a combination of drilling techniques and lithology. Drilling factors include type of drilling fluid, length of time drilling, and drilling technique (reverse circulation, core or rotary, air, etc.). Lithologic factors include degree of welding, porosity, type and degree of cementation or compaction, size, spacing and orientation of fractures or vugs, and type and degree of alteration.

Caliper logs often discriminate between different lithologies. For example:

- Soft, vitric ash-fall and reworked tuffs tend to be susceptible to caving and hole erosion. These formations give a smooth but out-of-gauge caliper signature.

- Well indurated, altered (zeolitized), ash-fall, reworked tuffs, and slightly to non-fractured ash-flows and lava flows tend to be more competent and not cave. Caliper logs through these lithologies will show in-gauge holes with relatively smooth signatures.

- In general, denser rocks, (ash-flow tuffs and rhyolite lavas) contain more fractures than do the less dense ash-fall tuffs. If these fractures are close enough together, some caving and/or breakouts may occur, resulting in a ragged caliper log signature.

Thus, the caliper log is a valuable reference tool for geologists, and is used in conjunction with other data sources to make geologic interpretations.

\subsubsection{Electric Log}

Except for metallic minerals, most minerals are good insulators. Typically, the only substance in a formation that will conduct electricity is the water contained in pore spaces, fractures, and adsorbed water on clay particles. The apparent resistivity of a formation is therefore dependent on two main factors: the amount of water it contains (porosity) and the resistivity of that water (composition). Other factors that affect resistivity to a lesser degree are (1) geometry of pore space, (2) temperature of logged interval, and (3) morphology and species of clay minerals (Carroll, 1990).

The depositional process affects porosity (which affects the amount of water the formation can hold), which in turn affects the apparent resistivity. Ash-fall tuffs generally exhibit greater porosity and, therefore, lower resistivity values than ash-flow tuffs. As the degree of welding 
increases in ash-flow tuffs, pore space decreases, resulting in higher apparent resistivity. Most welded ash-flow tuffs have little porosity and, consequently, have high resistivity values.

Within ash-fall and nonwelded ash-flow tuffs, the presence of alteration products such as zeolites and clays can also lower the apparent resistivity of the rock. When the water saturating a formation is relatively fresh (as at the NTS), the effects of ions in the rocks become an additional factor in lowering the measured resistivity of the rock. Pore water ion content increases with increasing alteration, causing a decrease in measured resistivity. In zones of equivalent porosity, more altered intervals tend to have lower measured resistivity values.

Table 3-3 lists typical apparent resistivity values of several formations and rock types in Yucca Flat. An example of a resistivity log from the Pahute Mesa area (Well ER-EC-1) is shown in Figure 3-5 to illustrate typical variations in resistivity values for welded and nonwelded units.

In addition to identifying welded tuff, electric logs historically were used at the NTS as a correlation tool and also to find zones of low resistivity that might be indicative of clay, which was potentially detrimental to containment of UGTs. Thus, electric logs are available for hundreds of boreholes, including all boreholes in the Tuff Pile area. This resource allowed comparison of resistivity logs and mineralogy data for Yucca Flat boreholes.

For example, Figure 3-6 shows data for a portion of Exploratory Hole UE-7f, located in the north-central portion of the Tuff Pile area, that illustrate the relationships between formation resistivity and mineralogy. Note that welded ash-flow tuffs (i.e., WTAs) within the TM-WTA HSU are characterized by high resistivity (greater than $250 \mathrm{ohm}$-meters) and a general absence of zeolite and clay. In contrast, zeolitic nonwelded to poorly welded tuffs (i.e., TCUs) within the LTCU and OSBCU HSUs are characterized by low resistivity (typically less than $50 \mathrm{ohm}$-meters) and significant percentages of zeolite and clay. The resistivity log indicates that no WTAs are present within the LTCU in UE-7f.

To further illustrate the absence of low-porosity, high-permeability zones (i e., welded ash-flow tuffs), a set of electric logs from seven Tuff Pile area drill holes is shown in Plate 1. As can be seen, the welded intervals of the Rainier Mesa Tuff within the Tuff Pile area exhibit the characteristic high resistivity signature associated with WTAs. Another obvious characteristic that all seven plots show is low resistivity throughout the zeolitized and/or argillized (LTCU and OSBCU) intervals below the welded Rainier Mesa Tuff. 
Table 3-3

Typical Apparent Resistivity Values of Several Formations and Rock Types in Yucca Flat

\begin{tabular}{||l|l||}
\hline \multicolumn{1}{|c|}{ Formation } & \multicolumn{1}{|c||}{ Apparent Resistivity (ohm-meters range) } \\
\hline \hline Alluvium & $20-300$ \\
\hline $\begin{array}{l}\text { Ammonia Tanks Tuff } \\
\text { nonwelded } \\
\text { partially to moderately welded } \\
\text { bedded }\end{array}$ & $125-450$ \\
\hline $\begin{array}{l}\text { Rainier Mesa Tuff } \\
\text { nonwelded } \\
\text { partially welded } \\
\text { moderately welded } \\
\text { densely welded }\end{array}$ & $220-300$ \\
\hline pre-Rainier Mesa, post-Grouse Canyon bedded tuff & $20-100$ \\
\hline Grouse Canyon Tuff (bedded, zeolitic) & $110-750$ \\
\hline upper Tunnel beds & $210-800$ \\
\hline Yucca Flat Tuff & $200-650$ \\
\hline older tuffs & $20-400+1,000+$ \\
\hline Paleozoic rocks & $50 \pm$ \\
\hline \hline
\end{tabular}

Source: Drellack, 1994b 


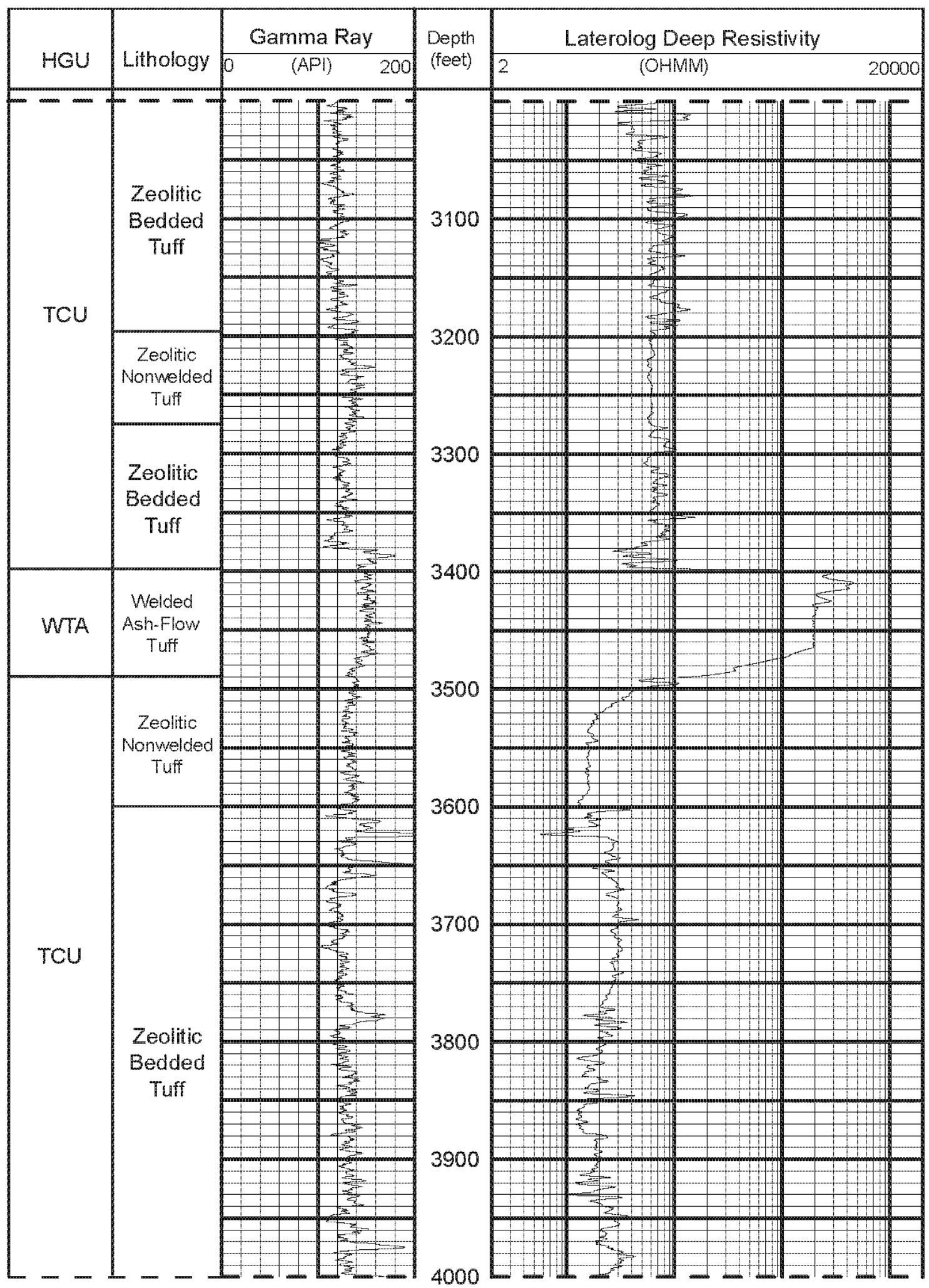

Figure 3-5

Resistivity Log from Well ER-EC-1 Showing Typical Signatures for Several Volcanic Rock Types 


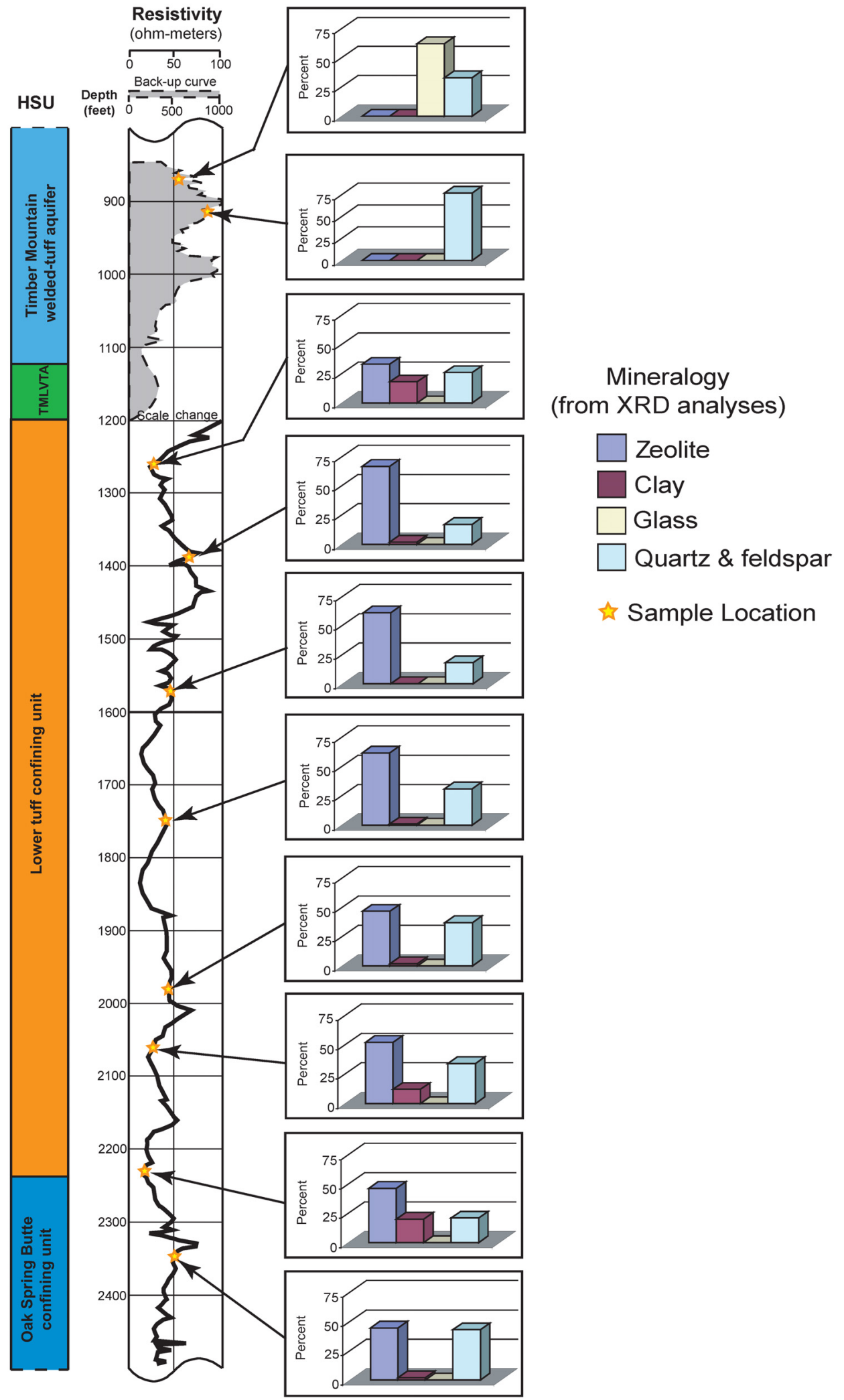

Figure 3-6

Continuous Resistivity Log Plot with Sample Mineralogy Data for Exploratory Hole UE-7f 
This page intentionally left blank. 


\subsection{Hydrostratigraphy}

Hydrostratigraphic units are determined on the basis of stratigraphy, described in Section 2.0, and incorporating the physical characteristics of tuffs as reflected in the assignment of HGUs, as determined by the methods described in Section 3.0. This section describes briefly the process of defining the hydrostratigraphy of the YF-CM HFM, and discusses the low probability that welded tuff units are present within specific portions of the TCU of the Tuff Pile area. For additional information about UGTA HSUs, see Prothro et al. (2009).

\subsection{Hydrostratigraphic Units of the Yucca Flat-Climax Mine HFM}

The hydrostratigraphic classification system is the foundation of the YF-CM HFM. This system was developed by first grouping the rocks within the model area into HGUs based on lithologic character, propensity to fracture, and the degree of secondary alteration. HGUs of similar character were then grouped by stratigraphic context into larger HSUs to facilitate mapping and 3-D model construction. A critical component of this step was the careful integration of Yucca Flat stratigraphy. The integration of stratigraphic concepts is important to ensure that individual HGUs grouped within HSUs, and the HSUs themselves, properly correlate within the model. The correlation of stratigraphic units and HSUs of the YF-CM HFM area is depicted graphically in Figure 4-1.

In the vicinity of the Tuff Pile, the YF-CM HFM consists of nine HSUs (from oldest to youngest): lower clastic confining unit (LCCU), LCA, ATCU, OSBCU, LTCU, Timber Mountain lower vitric-tuff aquifer (TM-LVTA), TM-WTA, Timber Mountain upper vitric-tuff aquifer (TM-UVTA), and AA.

The lower portion of the volcanic section is an important hydrogeologic layer because it separates the volcanic aquifer units from the underlying regional LCA over much of the NTS. The zeolitized tuffs in the lower part of the volcanic section were historically considered a TCU HGU (Winograd and Thordarson, 1975). However, for the YF-CM HFM the zeolitized tuffs in the Yucca Flat basin are divided into three separate confining unit HSUs based on their mineralogy (BN, 2006). These include the LTCU, OSBCU, and ATCU, as described in Section 4.2 and in Prothro (2005), and whose position is illustrated in Figure 4-1.

This separation was made to allow modelers flexibility to explore the possibility that the mineralogy of these rocks could have an effect on groundwater flow and contaminant transport. This separation, particularly of the OSBCU, also was based on the recognition that there is some 


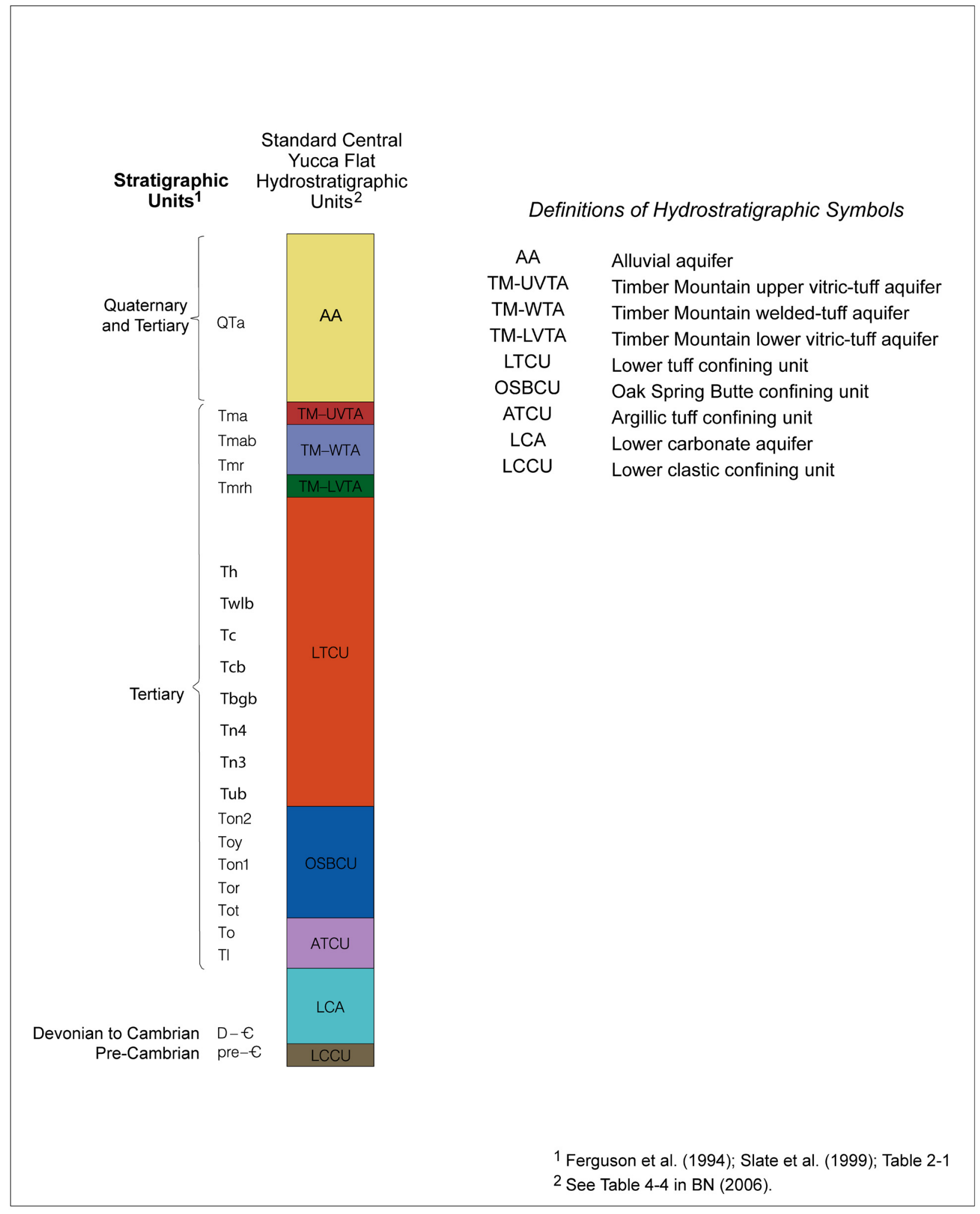

Figure 4-1

Correlation of Stratigraphic and Hydrostratigraphic Units in the Tuff Pile Area 
variability within this otherwise fairly homogeneous section, as described in Section 4.2 and in the following paragraphs. However, as will be shown, this variability does not encompass the inclusion of WTAs within any of the three TCU HSUs of Yucca Flat. The only exception is outside the Tuff Pile area, in extreme southern Yucca Flat. There, the welded Topopah Spring Tuff is present in the upper portion of the LTCU and is differentiated as a separate HSU (the Topopah Spring aquifer).

\subsection{Description of Tuff Confining Unit HSUs}

Data described above provide a basis for the recognition that the TCU rocks of the Tuff Pile area are not interbedded with welded tuffs. However, it is possible to recognize three subdivisions of the TCU based primarily on mineralogy, as mentioned in Section 3.1. These are described in the following paragraphs.

\subsubsection{Lower Tuff Confining Unit (LTCU)}

The uppermost of the three TCUs in Yucca Flat is the LTCU. Beneath Yucca Flat, the LTCU includes all zeolitic tuffs from the top of Tunnel bed 2 (base of the Tub Spring Tuff) to the base of the welded Rainier Mesa Tuff (Tmr) (i.e., TM-WTA). The LTCU is thick and extensive beneath Yucca Flat east of the Carpetbag and Topgallant faults where it is typically saturated. The LTCU generally correlates to the zeolite mineral (or ZC) zone of Prothro (2005). Zeolite content averages from 35 to over 70 percent and is the major mineral component of the LTCU (Table 3-2). Other reactive minerals, such as clay, are typically rare.

\subsubsection{Oak Spring Butte Confining Unit (OSBCU)}

The OSBCU consists of zeolitic tuffs and tuffaceous sediments that occur stratigraphically below the Tub Spring Tuff (i.e., base of the LTCU) down to the top of pervasive argillization (i.e., top of the ATCU). Most of the units composing the OSBCU are stratigraphically assigned to the Volcanics of Oak Spring Butte (Table 2-1 and Figure 4-1) and include such formations as Tunnel bed 2, Yucca Flat Tuff, Tunnel bed 1, Redrock Valley Tuff, tuff of Twin Peaks, and older volcanics. Although the OSBCU can include all stratigraphic units from the top of the Volcanics of Oak Spring Butte (base of the Tub Spring Tuff) to the top of pre-Tertiary rocks, the basal portion of the Tertiary section beneath Yucca Flat is commonly argillized, and these argillic rocks are assigned hydrostratigraphically to the ATCU (see Section 4.2 .3 below).

Most of the volcanic units within the OSBCU consist primarily of zeolitic nonwelded tuff, but this HSU also includes several intercalated devitrified or quartzo-feldspathic to weakly zeolitized, nonwelded to partially welded, ash-flow tuff deposits. Stratigraphically, these older ash-flow tuffs are assigned to the Yucca Flat Tuff, Redrock Valley Tuff, and tuff of Twin Peaks, 
all formations of the Volcanics of Oak Spring Butte. Because portions of these ash-flow tuff units were devitrified soon after deposition, there was little glass to be converted to zeolite. The OSBCU was created to address the hydrogeologic and mineralogic variability these older, devitrified ash-flows impart to an otherwise zeolitic interval. The OSBCU generally correlates to the felsic mineral (or FS) zone of Prothro (2005).

The relatively diverse lithologic composition of the OSBCU, particularly the presence of devitrified to quartzo-feldspathic ash-flow tuff, may result in hydrologic properties somewhat different from those for the more lithologically homogeneous confining HSUs such as the LTCU. In addition, the lithologic diversity of the OSBCU results in a more diverse mineralogy that may have important ramifications with regard to retarding radionuclides via sorption and ion exchange processes (Zavarin et al., 2004; BN, 2006; SNJV, 2007).

As a whole, the OSBCU has a relatively high average zeolite content of over 25 percent (Table 3-2). As mentioned above, the presence of several weakly zeolitized to devitrified ash-flow tuffs within the OSBCU, however, results in an overall zeolite content lower than in the LTCU, where 40 to 60 percent total zeolite is common. Other reactive minerals are generally rare, although clay content averages 11 percent. In addition to the possibly devitrified ash-flow tuff units, quartzo-feldspathic alteration also seems to be present as evidenced by the higher quartz and feldspar content (Table 3-2). Because these older ash-flow tuffs were not strongly welded, they lack cooling joints; and because of their micro-crystalline nature, quartzofeldspathic rocks are generally not hydraulically conductive.

\subsubsection{Argillic Tuff Confining Unit (ATCU)}

Volcanic rocks and tuffaceous sediments that occur at the base of the Tertiary section beneath Yucca Flat are commonly argillized (BN, 2006) and are assigned to the ATCU. The ATCU typically includes the oldest Tertiary-age units that lie directly on top of pre-Tertiary rocks beneath Yucca Flat, including the stratigraphically distinct paleocolluvium. Lithologically, the ATCU includes highly argillized bedded tuff, ash-flow tuff, tuffaceous sediments, and paleocolluvium.

Beneath Yucca Flat, the ATCU is present east of the Carpetbag and Topgallant faults and in the western sub-basin of Areas 2 and 4. The HSU is typically saturated. The ATCU correlates to the argillic (or AR) zone of Prothro (2005). The ATCU is characterized by high clay and low zeolite content (Table 3-2). In some areas, the paleocolluvium, typically included within the ATCU, contains abundant carbonate clasts. 


\subsection{Potential Welded Ash-Flow Tuffs (Aquifers) within the LTCU and OSBCU}

Within the stratigraphic section comprising the LTCU and the underlying OSBCU in the Tuff

Pile area, there are seven stratigraphic units that include ash-flow tuff within their total extent on and near the NTS. While these units may be strongly welded in other parts of the NTS, both observational and analytical data clearly indicate that the LTCU in the Tuff Pile area consists of pervasively zeolitic, nonwelded to poorly welded tuffs that are classified as TCUs in the YF-CM $\operatorname{HFM}(\mathrm{BN}, 2006)$.

As mentioned in Section 4.2.2, the oldest ash-flow tuff units within the OSBCU may be partially welded and zeolitic to devitrified to quartzo-feldspathic. Table 4-1 correlates stratigraphic units, lithology, HGUs, and HSUs for geologic units occurring in the Tuff Pile area. Tuff units that occur in places as welded ash-flow tuffs and are listed as low-porosity, high-permeability units in Boryta et al. (in review) are noted with the footnote "c" in the lithology column of Table 4-1. Additional information for each of these potential ash-flow tuff units is provided in the following paragraphs.

\subsubsection{Grouse Canyon Tuff}

The Grouse Canyon Tuff in the vicinity of Yucca Flat ranges in thickness from 0 to $48.8 \mathrm{~m}$ ( 0 to $160 \mathrm{ft}$ ). In outcrops immediately north of Yucca Flat, the Grouse Canyon Tuff is a simple cooling unit of densely welded comenditic (high-silica, peralkaline) ash-flow tuff (a WTA), which is generally devitrified except for a thin vitrophyre locally present at the base of the ashflow. A significant ash-fall is present beneath the ash-flow tuff, as shown in the photograph in Figure 4-2. However, in the subsurface of central and southern Yucca Flat, only the ash-fall tuff lithofacies (bedded Grouse Canyon Tuff [Tbgb]) is present and usually is only 6.1 to $9.1 \mathrm{~m}$ (20 to $30 \mathrm{ft}$ ) thick. In northern Yucca Flat, the Tbgb is vitric and is included in the TM-LVTA. In the southern half of Yucca Flat, including the Tuff Pile area, this unit is strongly zeolitic and is included in the LTCU (Table 4-1). Figure 4-3 shows the extent and depth to the top of the Belted Range aquifer HSU (consisting of the welded Grouse Canyon Tuff). Note that except for a limited occurrence in northern Yucca Flat, this WTA does not occur in the subsurface of Yucca Flat. 
Table 4-1

Stratigraphic Nomenclature and Correlation with Hydrogeologic and Hydrostratigraphic Units for the Tuff Pile Area ${ }^{a}$

\begin{tabular}{|c|c|c|c|c|c|}
\hline $\begin{array}{c}\begin{array}{c}\text { Num- } \\
\text { ber }\end{array} \\
\end{array}$ & Stratigraphic Unit & $\begin{array}{c}\text { Map } \\
\text { Symbol }\end{array}$ & Lithology ${ }^{b}$ & HGU $^{b}$ & HSU $^{b}$ \\
\hline 29 & Quaternary/Tertiary alluvium & QTa & $A L$ & AA & AA \\
\hline 28 & Ammonia Tanks Tuff & Tma & WT & WTA/VTA & TM-WTA \\
\hline 27 & Ammonia Tanks Tuff (bedded) & Tmab & BED & WTA/VTA & TM-WTA/TM-LVTA \\
\hline 26 & Rainier Mesa Tuff & Tmr & WT & WTA & TM-WTA \\
\hline 25 & tuff of Holmes Road & Tmrh & BED/RWT & VTA & TM-LVTA \\
\hline 24 & Paintbrush Group & $T p$ & BED & TCU & LTCU \\
\hline 23 & Calico Hills Fm. & Th & BED & TCU & LTCU \\
\hline 22 & Wahmonie Fm. & Tw & BED & TCU & LTCU \\
\hline 21 & Crater Flat Group & Tc & BED & TCU & LTCU \\
\hline 20 & Grouse Canyon Tuff (bedded) & Tbgb & $\mathrm{BED}^{\mathrm{C}}$ & TCU & LTCU \\
\hline 19 & Tunnel bed $4 \mathrm{~K}$ & Tn4K & BED & TCU & LTCU \\
\hline 18 & Tunnel bed 4J & Tn4J & BED & TCU & LTCU \\
\hline 17 & Tunnel bed 4FGH & Tn4FGH & BED & TCU & LTCU \\
\hline 16 & Tunnel bed 4E-equivalent & Tn4E & N-PWT ${ }^{\mathrm{C}}$ & TCU & LTCU \\
\hline 15 & Tunnel bed 4ABCD & Tn4ABCD & BED & TCU & LTCU \\
\hline 14 & Tunnel bed 3D & Tn3D & BED & TCU & LTCU \\
\hline 13 & Tunnel bed 3BC-equivalent & Tn3BC & NWT $^{\mathrm{c}}$ & TCU & LTCU \\
\hline 12 & Tunnel bed $3 \mathrm{~A}$ & Tn3A & BED & TCU & LTCU \\
\hline 11 & Tub Spring Tuff & Tub & $\mathrm{BED}^{\mathrm{C}}$ & TCU & LTCU \\
\hline 10 & Tunnel bed 2 & Ton2 & BED & TCU & OSBCU \\
\hline 9 & Yucca Flat Tuff & Toy & $\mathrm{PWT}^{\mathrm{C}}$ & TCU & OSBCU \\
\hline 8 & Tunnel bed 1 & Ton1 & BED & TCU & OSBCU \\
\hline 7 & older tuffs & To & BED/RWT & TCU & OSBCU \\
\hline 6 & Redrock Valley Tuff & Tor & $\mathrm{PWT}^{\mathrm{c}}$ & TCU & OSBCU \\
\hline 5 & older tuffs & To & BED/RWT & TCU & OSBCU/ATCU \\
\hline 4 & tuff of Twin Peaks & Tot & $\mathrm{PWT}^{\mathrm{c}}$ & TCU & OSBCU \\
\hline 3 & older tuffs & To & BED/RWT & TCU & ATCU \\
\hline 2 & Tertiary paleocolluvium & Tlc & PCL & TCU & ATCU \\
\hline 1 & Paleozoic carbonate rock & $\mathrm{Pz}$ & CA & $\mathrm{CA}$ & LCA \\
\hline
\end{tabular}




\section{Table 4-1 \\ Stratigraphic Nomenclature and Correlation with Hydrogeologic and Hydrostratigraphic Units for Geologic Units in the Tuff Pile Area ${ }^{\text {a }}$ (continued)}

a Adapted from BN, 2006.
b Explanation of abbreviations:

Hydrogeologic Unit (HGU)

AA alluvial aquifer

WTA welded-tuff aquifer

VTA vitric-tuff aquifer

TCU tuff confining unit

CA
Lithology

$\mathrm{AL} \quad$ alluvium

WT welded tuff

BED bedded tuff

RWT re-worked tuff

N-PWT non- to partially welded tuff

PWT partially welded tuff

$\mathrm{PCL}$ paleocolluvium

CA dolomite and limestone
Hydrostratigraphic Unit (HSU)

AA alluvial aquifer

TM-WTA Timber Mountain welded-tuff aquifer

TM-LVTA Timber Mountain lower vitric-tuff aquifer

LTCU lower tuff confining unit

OSBCU Oak Spring Butte confining unit

ATCU argillic tuff confining unit

LCA lower carbonate aquifer

c Unit described as a welded tuff (low porosity, high permeability) in Boryta et al. (in review).

The two lithologies of the Grouse Canyon Tuff are easily distinguished in the field and in hand sample. As can be seen in Figure 4-2, the cliff-forming welded ash-flow tuff is easily distinguished from the slope-forming zeolitic ash-fall tuff. The photograph presented in Figure 4-4 shows the distinctive zeolitic Tbgb ash-fall tuff core from Exploratory Hole UE-7f (the only Grouse Canyon Tuff lithology penetrated in this hole). Figure 4-5 shows a photograph of a sample of the zeolitic, ash-fall lithology of the Tbgb from Exploratory Hole UE-7f next to a sample of welded ash-flow Grouse Canyon Tuff from Exploratory Hole UE-12t\#3, again illustrating the obvious difference between the two lithologies.

\subsubsection{Tunnel Formation, Tunnel 4 Member, Beds $4 E$}

Beds 4E is thought to be equivalent to the tuff of the same name present in Rainier Mesa. In Yucca Flat, beds 4E is characterized by the presence of very large (up to 3 centimeters [cm]) lithic fragments of dark red, aphanitic rhyolite and large pumice (greater than $1 \mathrm{~cm}$ ) (Table 2-2). In Yucca Flat, beds 4E is typically zeolitic, but exhibits the massive (non-bedded) characteristic of a nonwelded to partially welded ash-flow tuff within an otherwise bedded tuff sequence. A 5.2-m (17-ft) interval of nonwelded Tn4E in Exploratory Hole UE-7f is shown in Figure 4-6. The typical lack of fractures is also evident in this photo (all breaks visible are handlinginduced). Note also the round pumice in Figure 4-7, which is indicative of a nonwelded tuff (welding of ash-flow tuff tends to flatten pumice). 


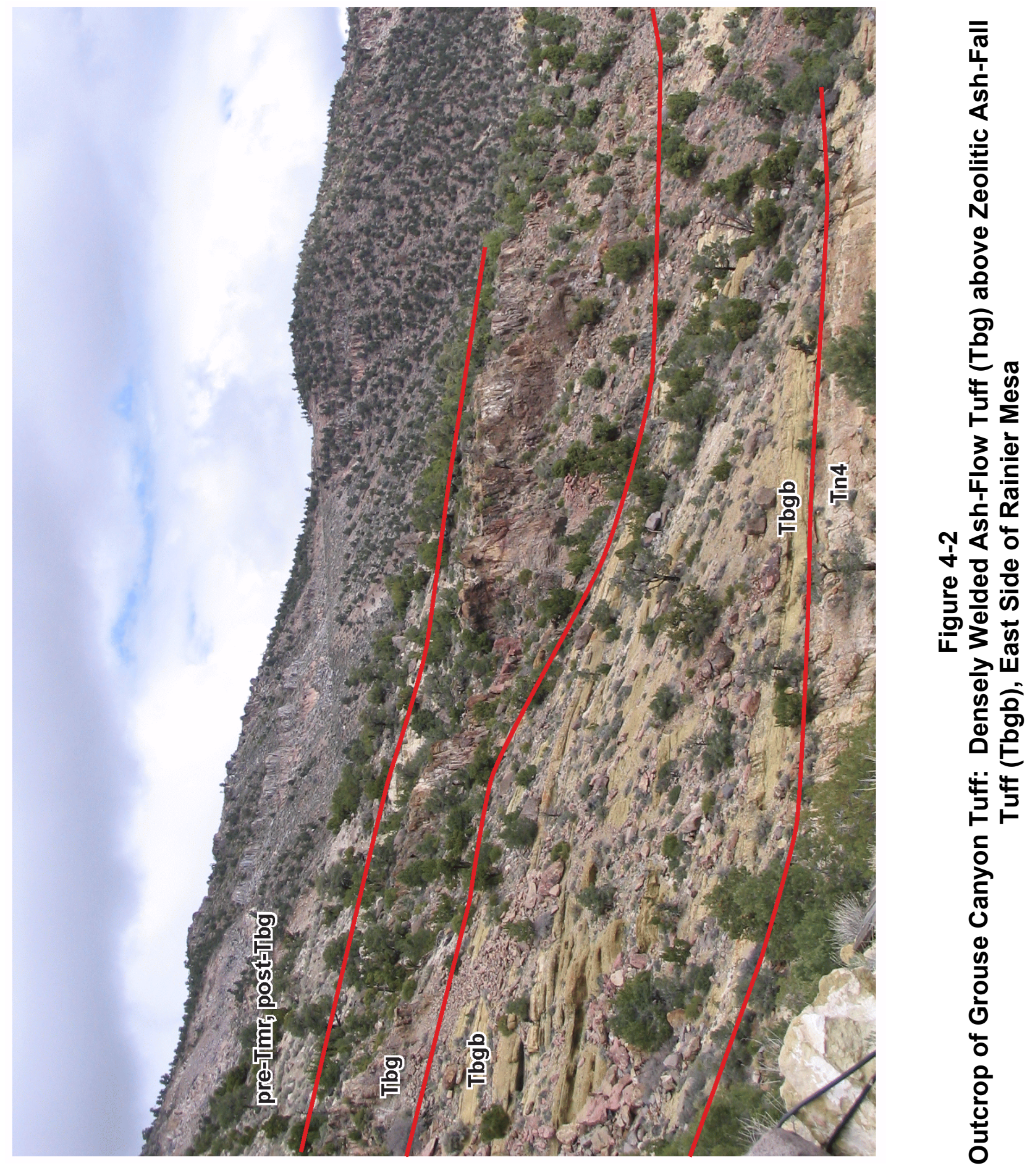




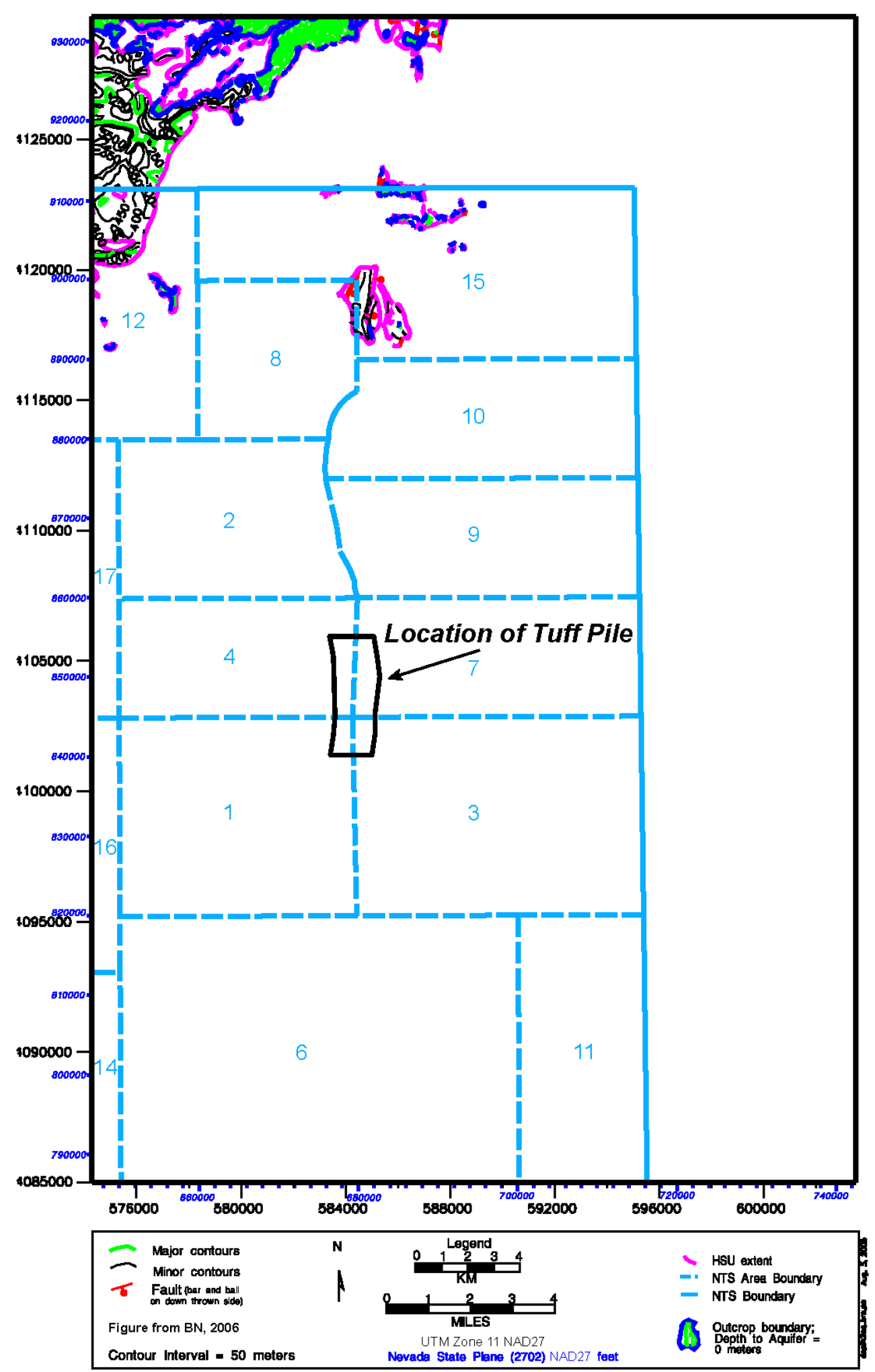

Figure 4-3

Depth to the Belted Range Aquifer in the Yucca Flat-Climax Mine Hydrostratigraphic Framework Model 


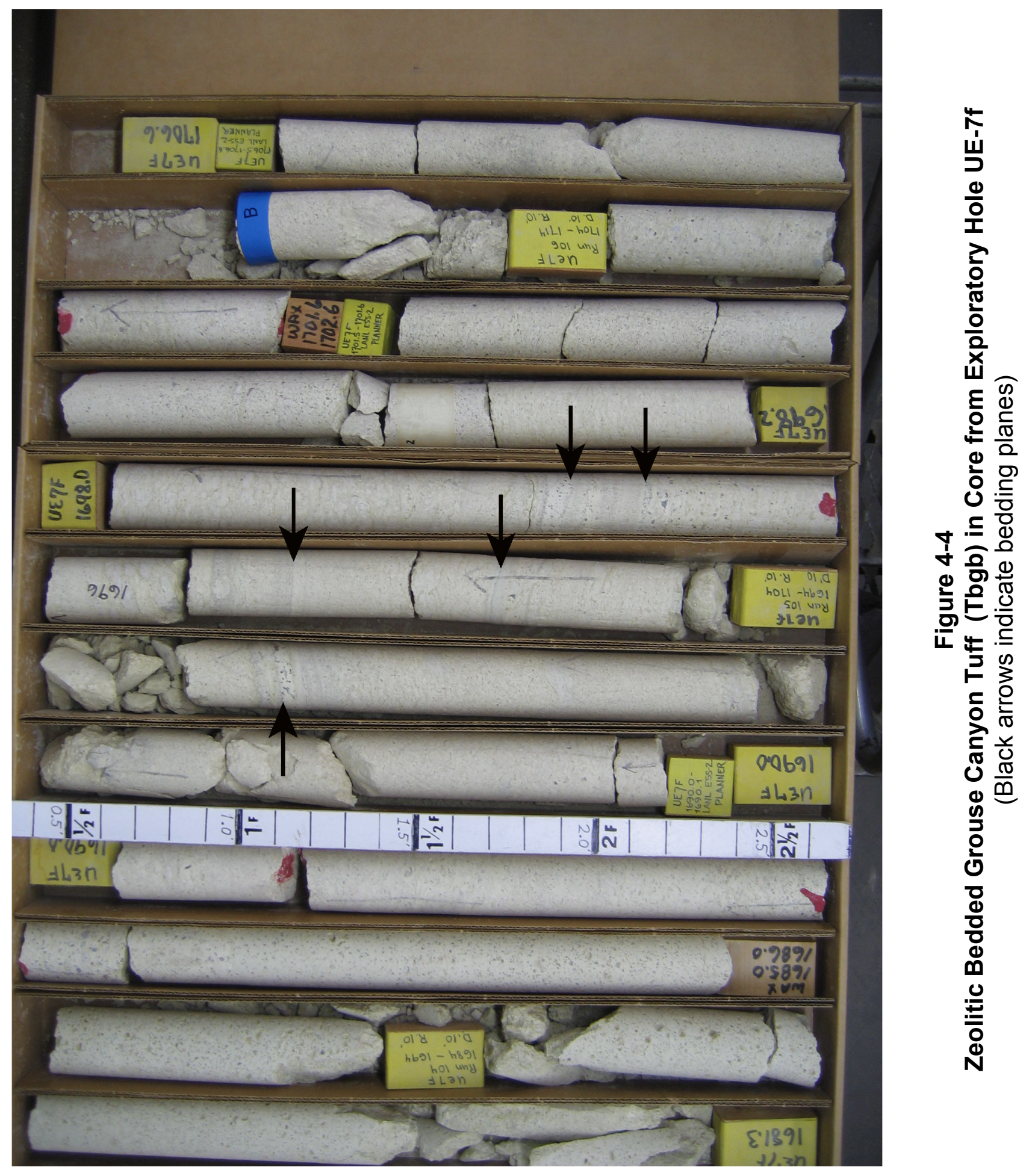



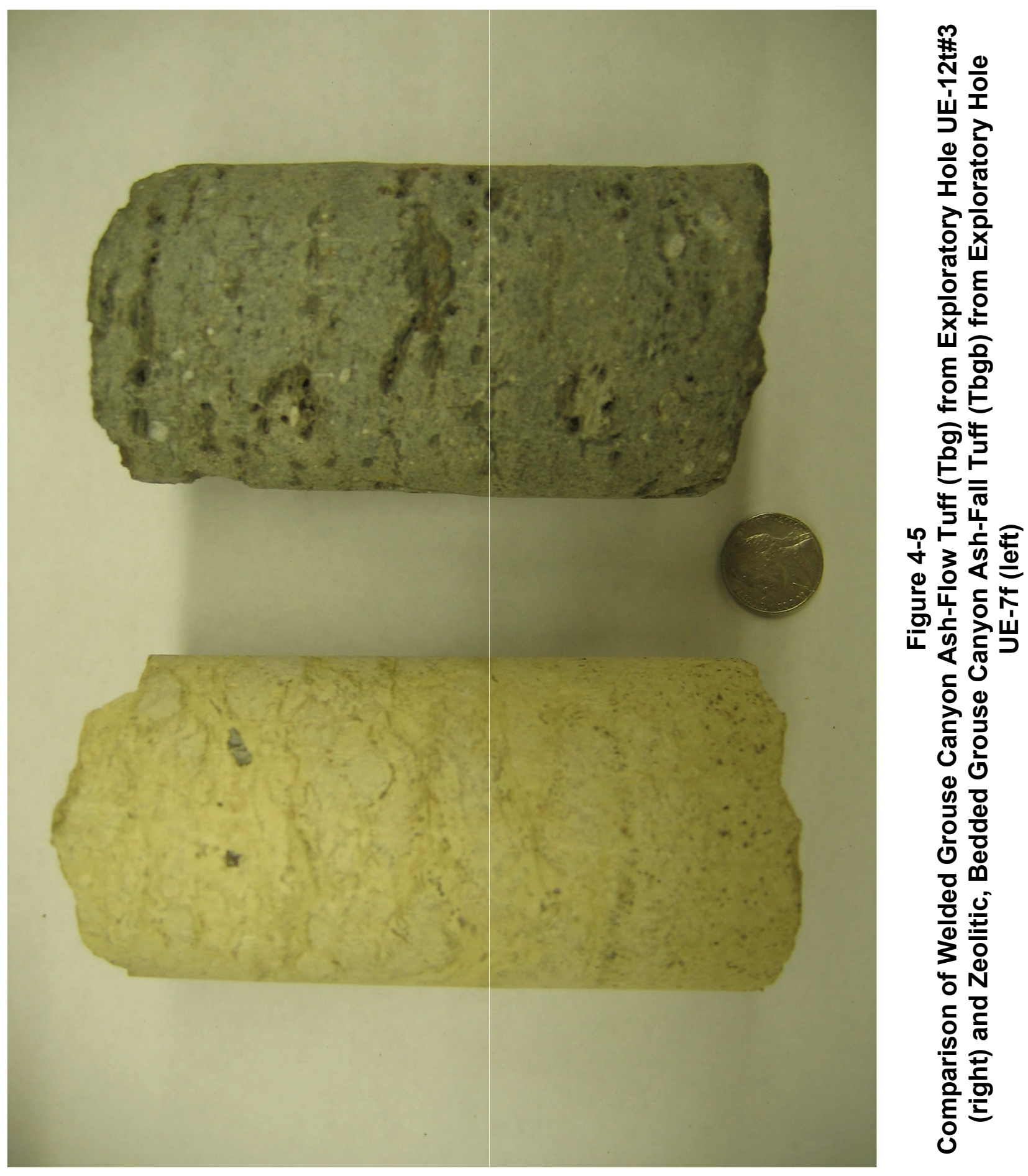


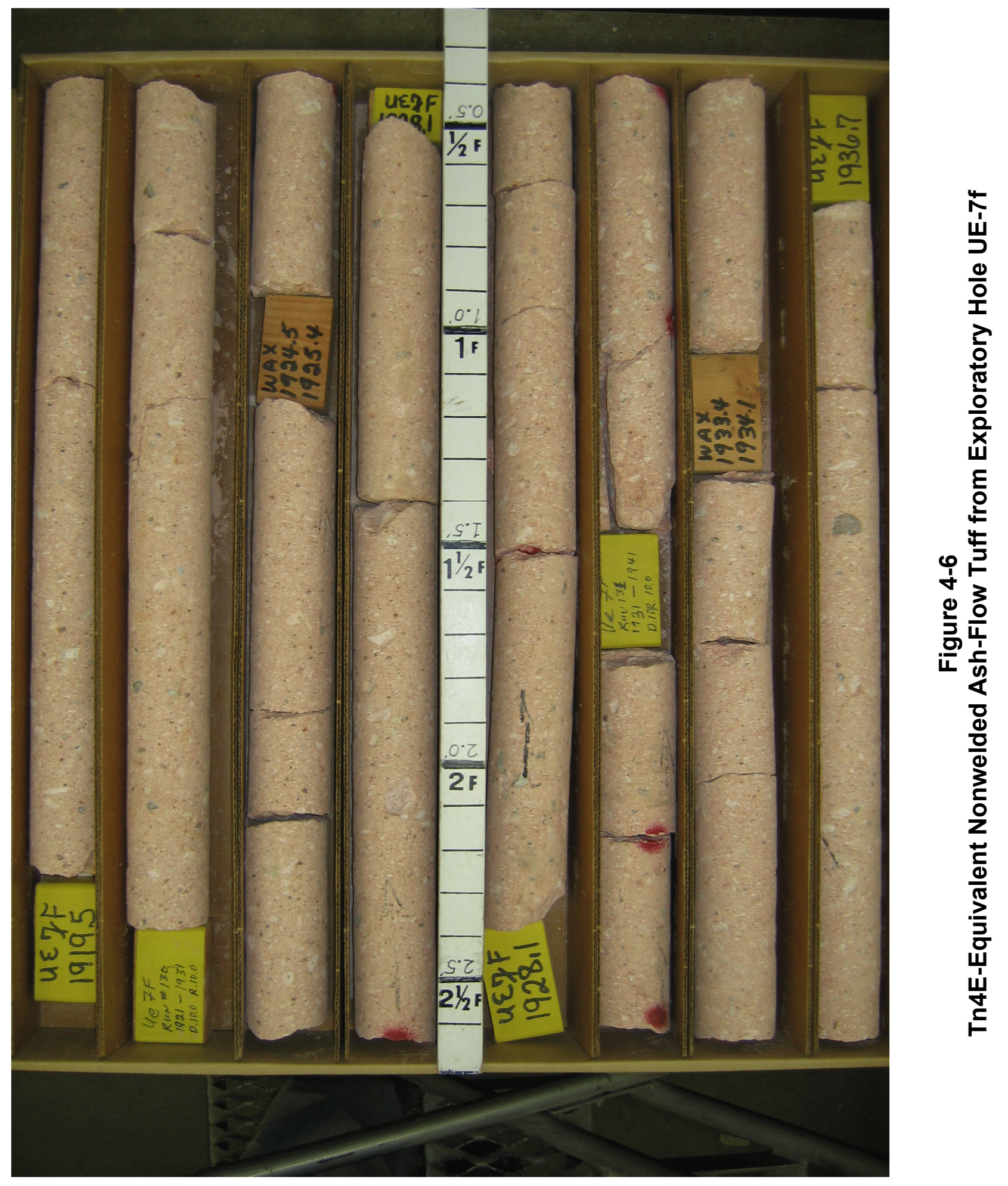



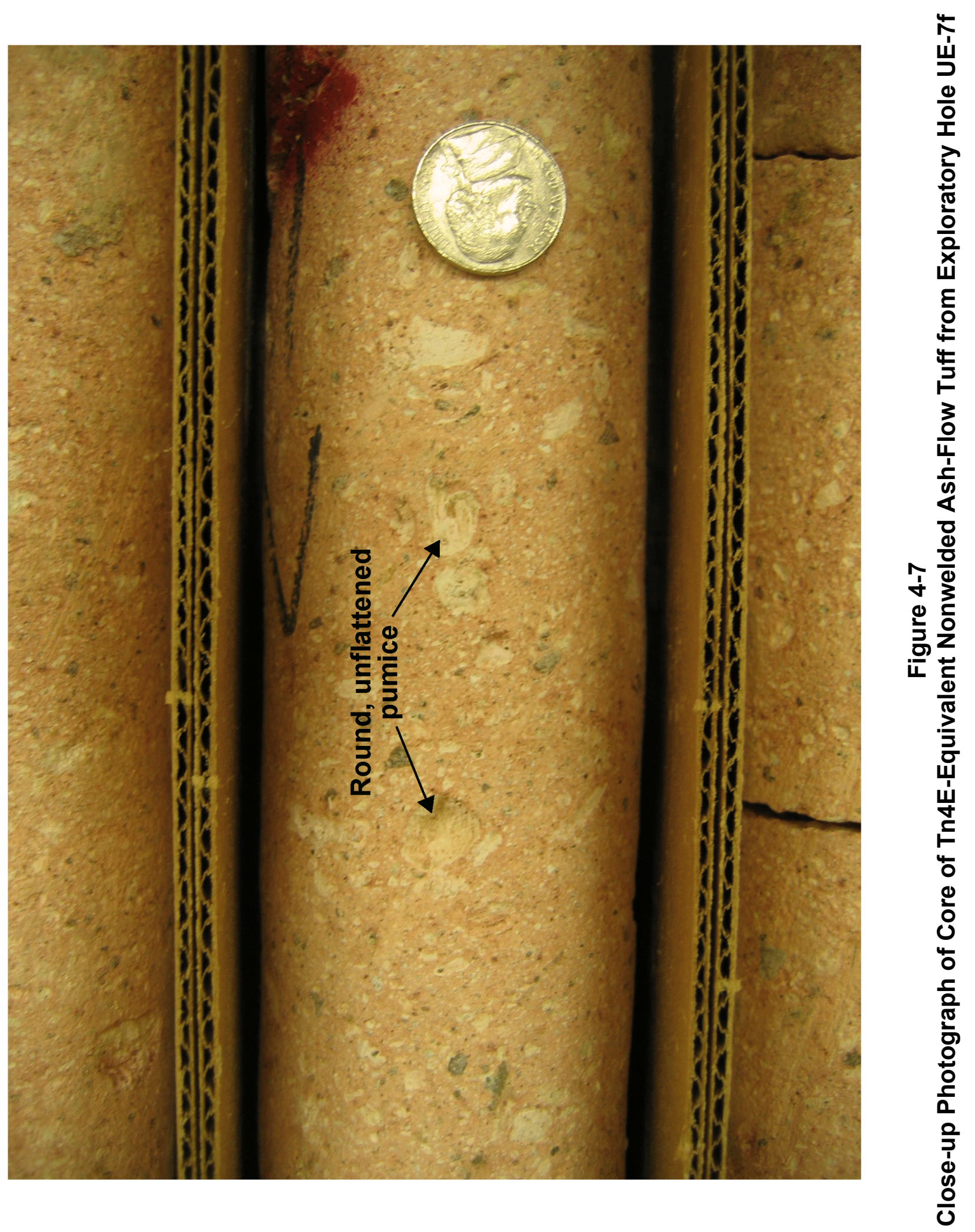


\subsubsection{Tunnel Formation, Tunnel 3 Member, Beds 3BC}

Beds $3 \mathrm{BC}$ is a rather unique tuff unit identified in the middle of Tunnel Formation, 3 Member, Yucca Flat. This unit occurs both as a bedded tuff and as a nonwelded to partially welded ash-flow tuff. The ash-flow tuff lithofacies, usually identified as Tunnel Bed 3BC-equivalent, is present in the Tuff Pile area, where it is up to $24.7 \mathrm{~m}$ (81 ft) thick (Table 2-2 and Appendix A). The unit is phenocryst-poor, contains relict glass shards and shard molds, and is strongly zeolitic (Table 2-2). Figures 4-8a and 4-8b show two intervals of beds 3BC in Exploratory Hole UE-7f, from the depths of 624.8 to $634.3 \mathrm{~m}$ (2,050 to $2,081 \mathrm{ft})$ and 620.0 to $645.0 \mathrm{~m}$ (2,034 to $2,116 \mathrm{ft})$, respectively, demonstrating its nonwelded character.

\subsubsection{Tub Spring Tuff}

Like the Grouse Canyon Tuff, the Tub Spring Tuff occurs as two vastly different lithofacies, a welded ash-flow tuff and a bedded ash-fall tuff. To the north of Yucca Flat, the Tub Spring Tuff is a simple cooling unit of densely welded to nonwelded, devitrified, comenditic (high-silica, peralkaline) ash-flow tuff. Figure 4-9 shows the resistant welded lithofacies of Tub Spring Tuff in outcrop at Rainier Mesa, and Figure 4-10 shows a closer view of the ash-flow tuff lithofacies.

In the Tuff Pile area, only the bedded ash-fall lithofacies of the Tub Spring Tuff occurs, and due to its position below the water table, it is typically zeolitic (Table 2-2). The distinctive "apple green" color of a zeolitic peralkaline ash-fall tuff is apparent in Figure 4-11. Figure 4-12 illustrates the difference between welded Tub Spring ash-flow tuff from Exploratory Hole UE-12t\#3 at Rainier Mesa with the ash-fall tuff lithofacies penetrated in Exploratory Hole UE-7f in central Yucca Flat. Again, there is a conspicuous difference between the welded tuff and ash-fall tuff lithofacies, making it unlikely for any confusion distinguishing the two lithofacies of the Tub Spring Tuff. Figure 4-13 shows the extent and depth to the top of the Tub Spring aquifer (TUBA) HSU. Note that this WTA does not occur in the subsurface of Yucca Flat. Only the ash-fall is present in the subsurface of Yucca Flat.

\subsubsection{Yucca Flat Tuff}

The Yucca Flat Tuff of the Volcanics of Oak Spring Butte Group is discontinuously present in the subsurface of eastern Yucca Flat. The Yucca Flat Tuff is a nonwelded to partially welded, zeolitized ash-flow tuff (Table 2-2). In the Tuff Pile area it is devitrified to zeolitic, less than $32 \mathrm{~m}$ (105 ft) thick, and discontinuously present (Appendix A). The nonwelded to partially welded Yucca Flat Tuff from Exploratory Hole UE-7f is shown in Figure 4-14. Note that the pumice are not significantly flattened, as would be diagnostic of a welded tuff. 


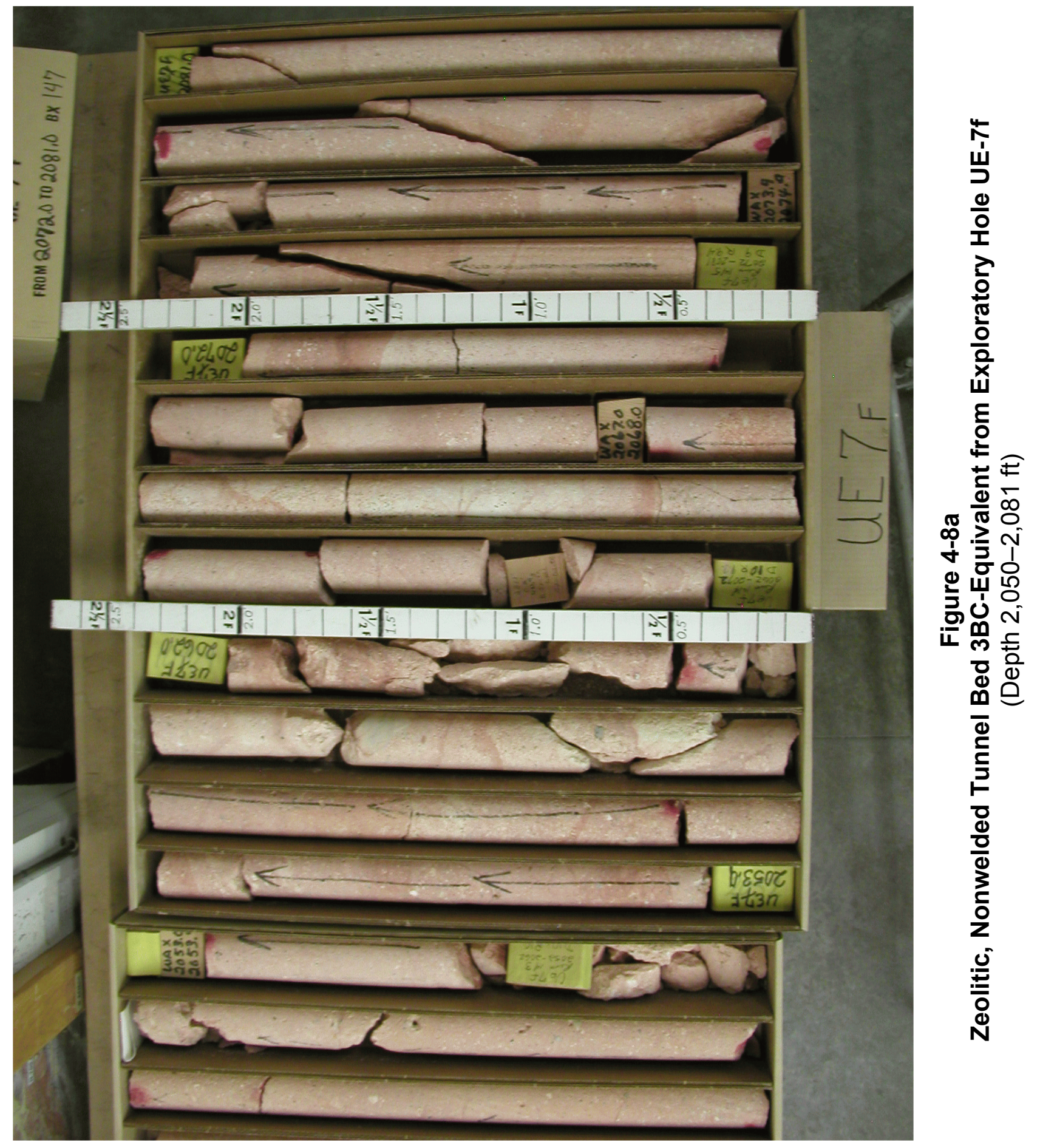



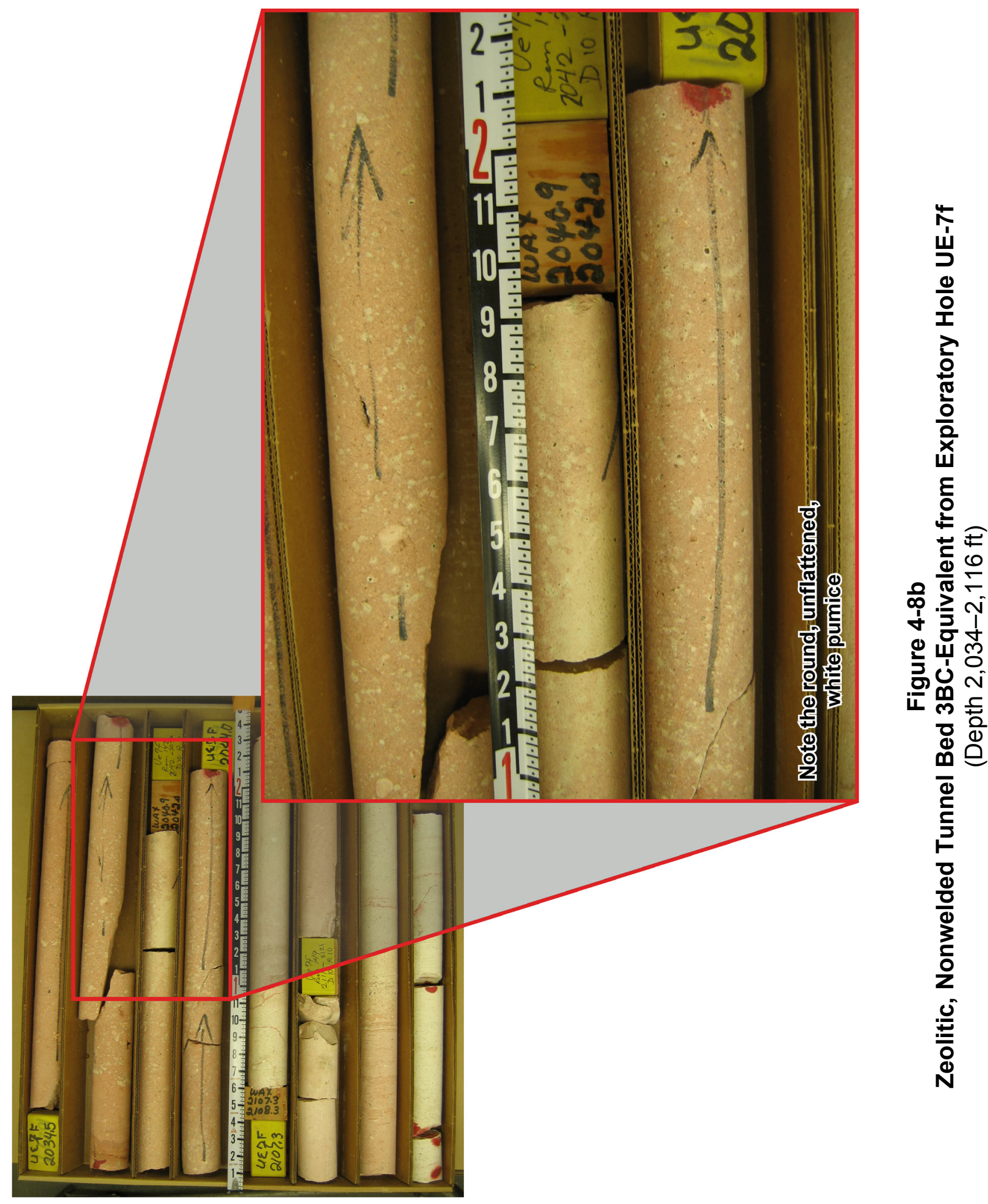


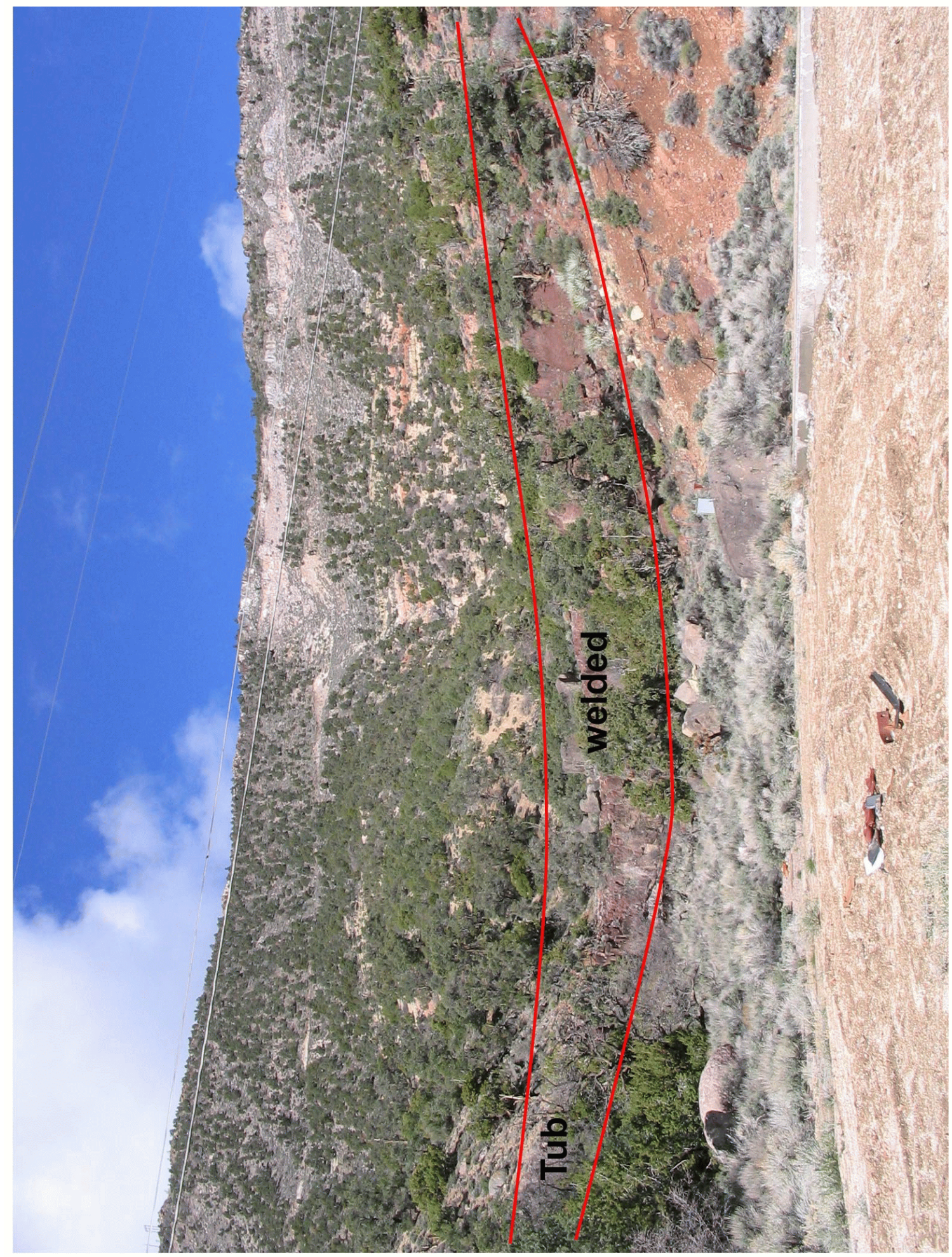

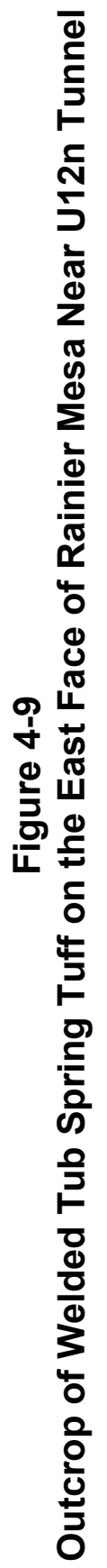




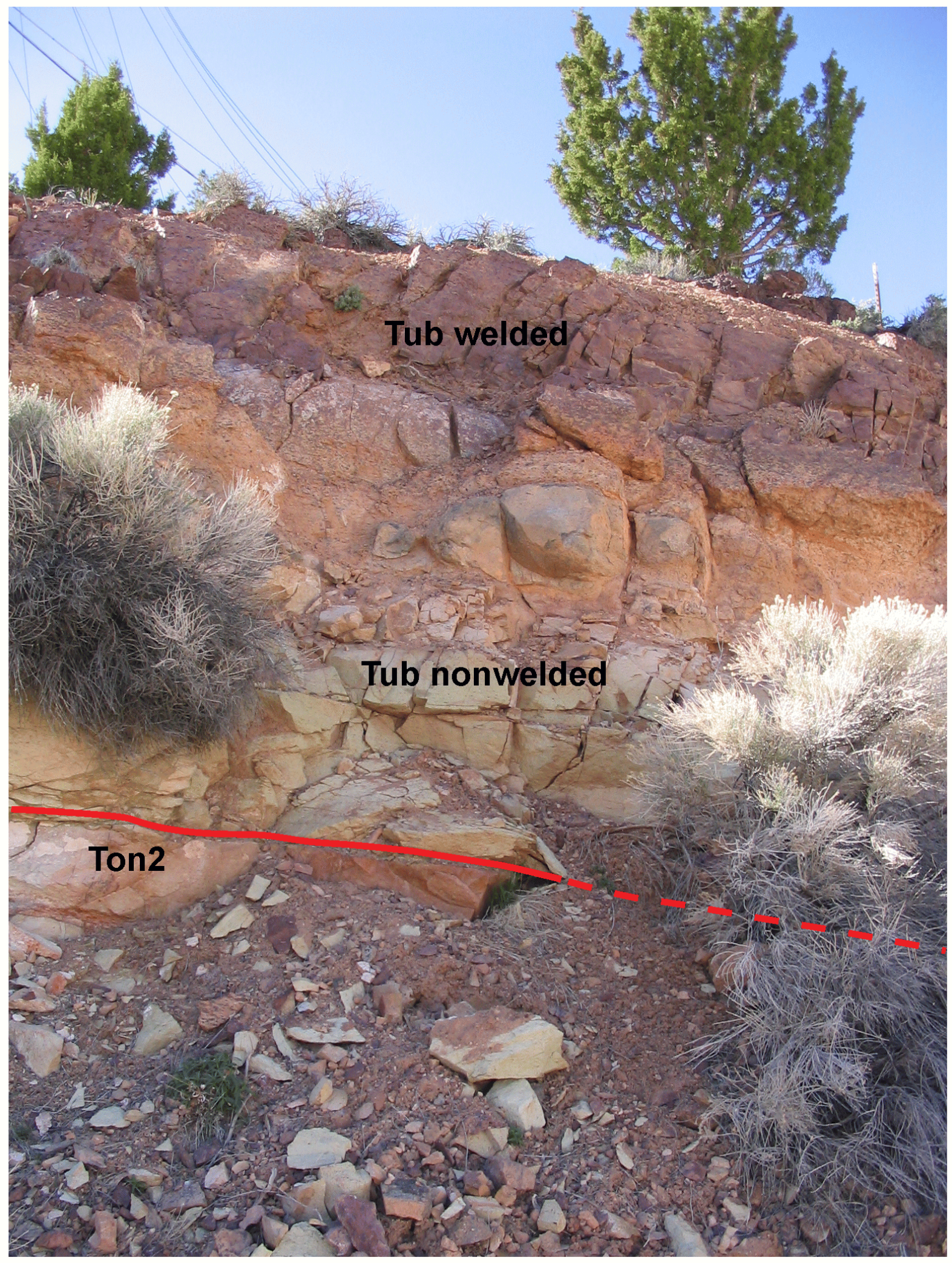

Figure 4-10

Outcrop of Tub Spring Tuff at Rainier Mesa 


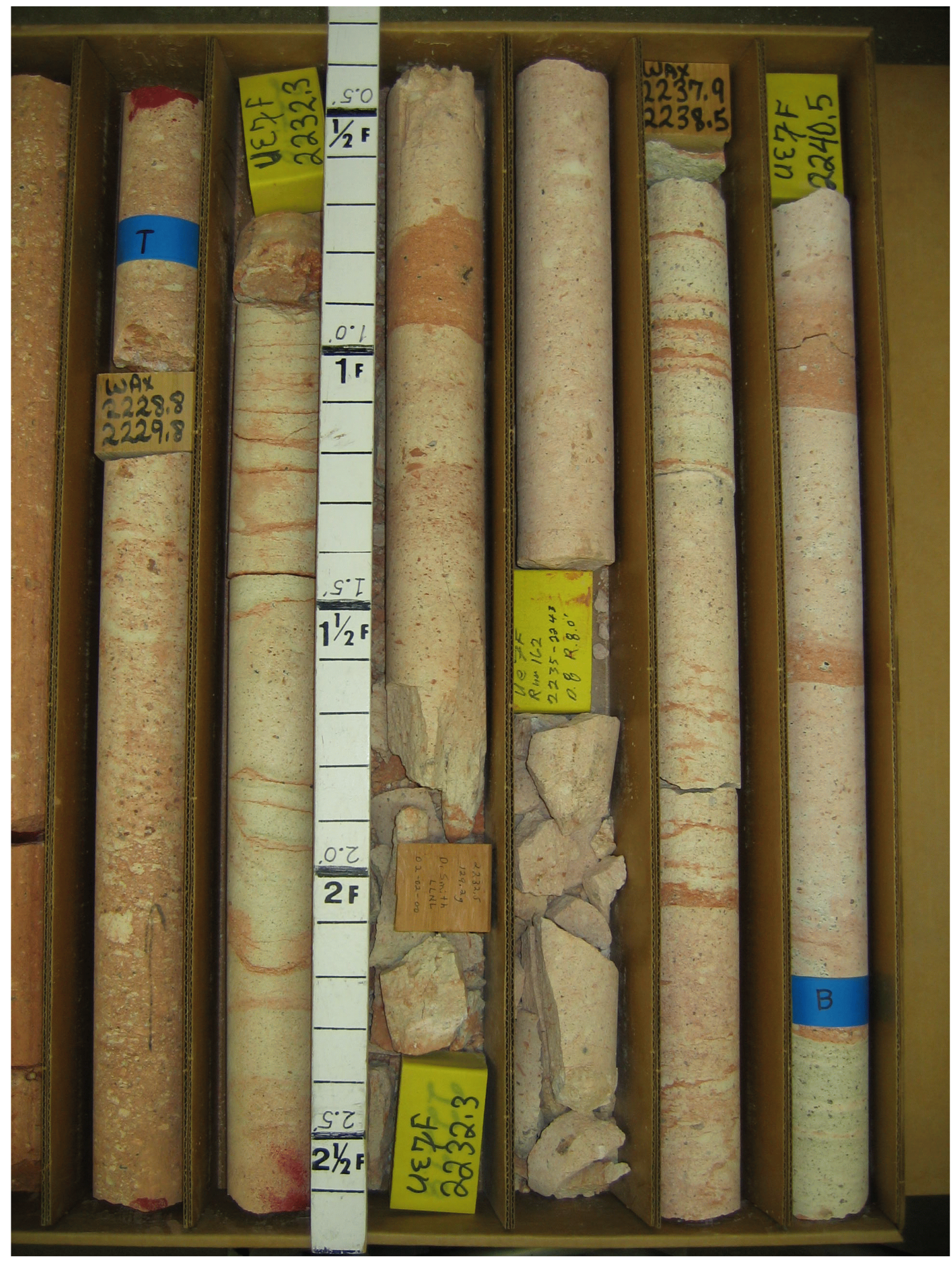

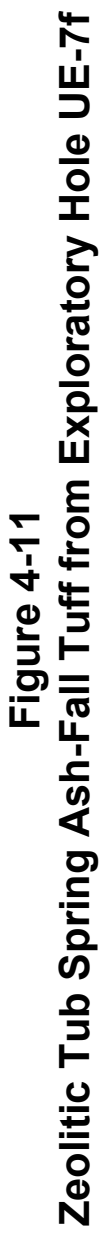




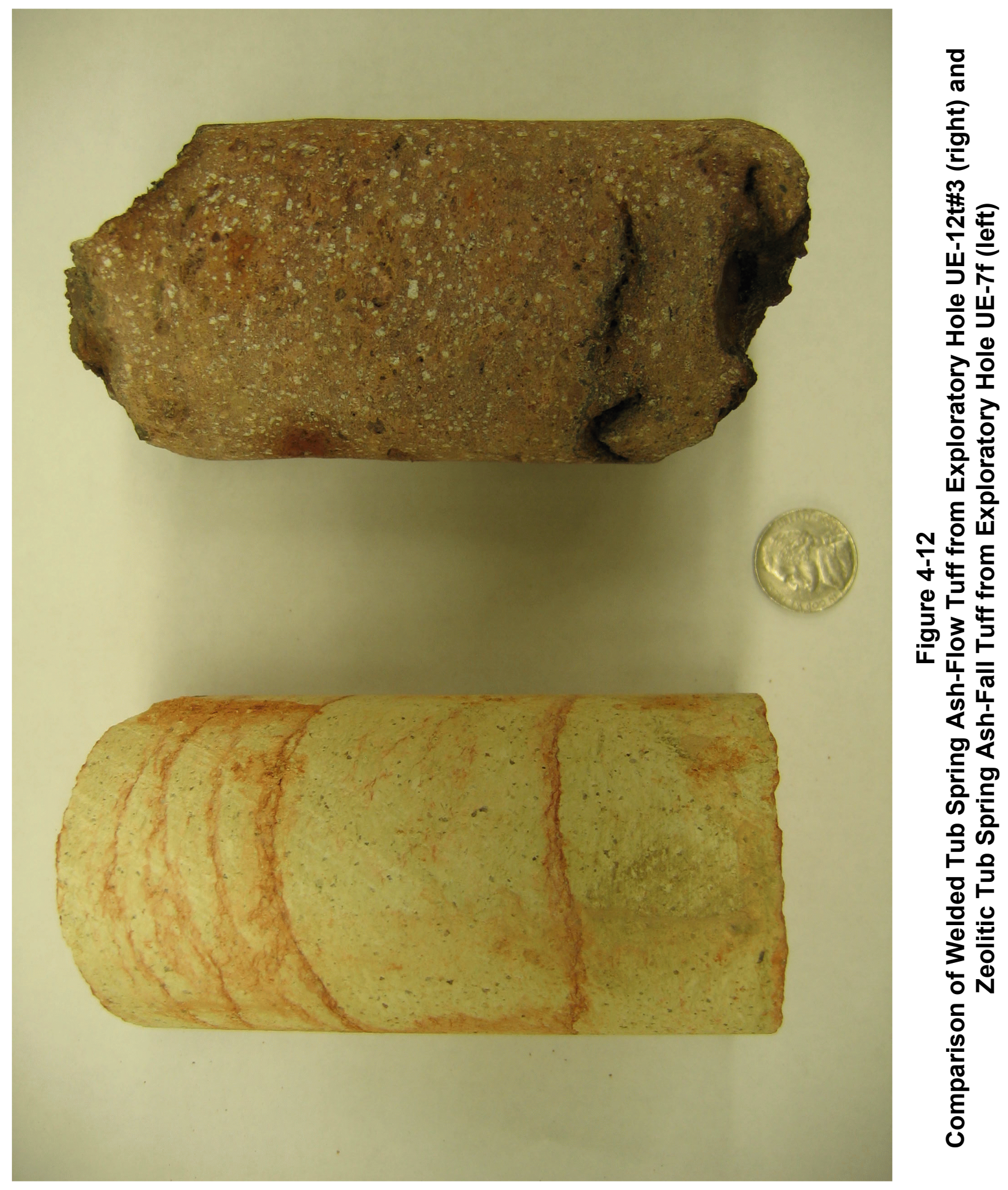




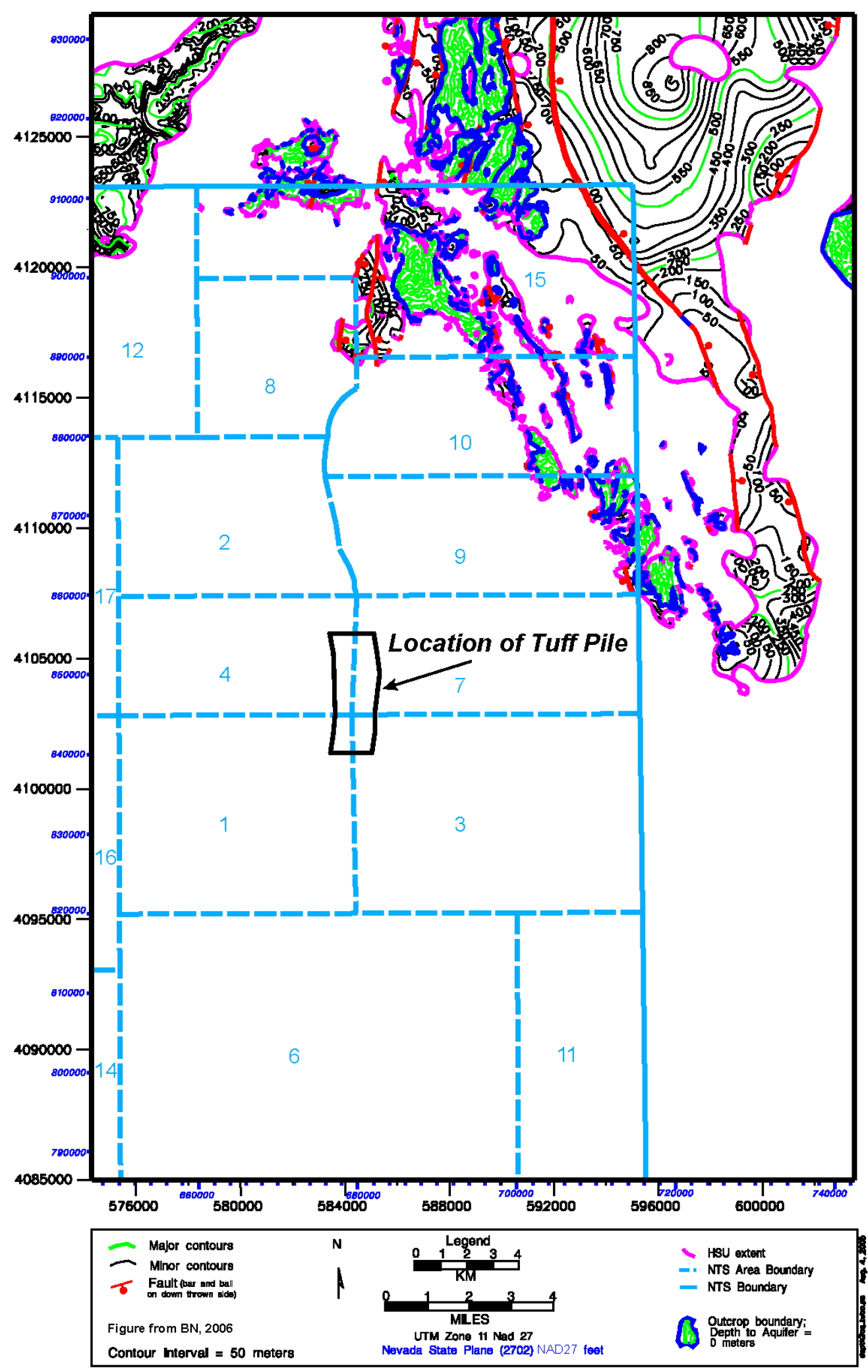

Figure 4-13

Depth to the Tub Spring Aquifer in the Yucca Flat-Climax Mine Hydrostratigraphic Framework Model 


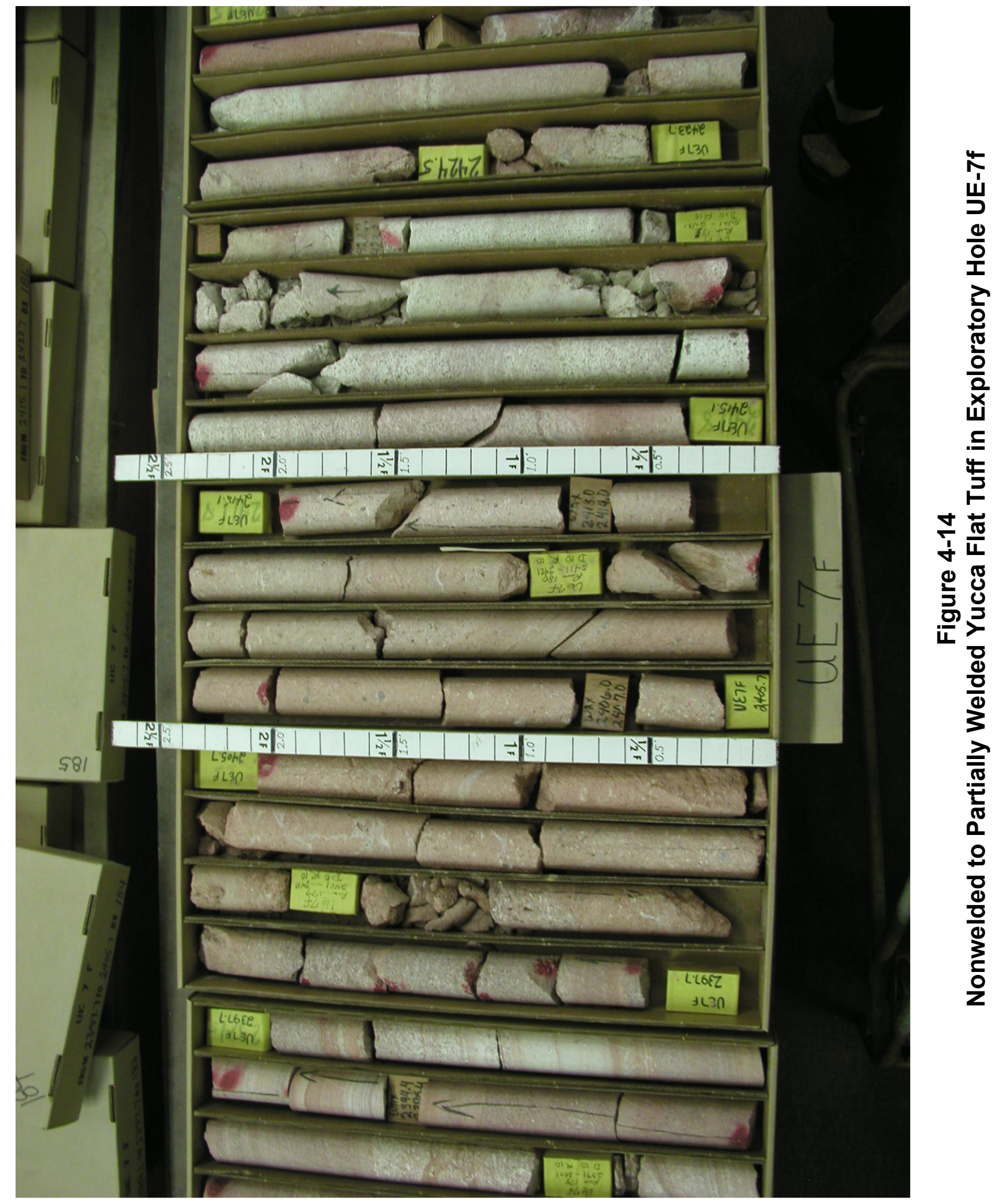




\subsubsection{Redrock Valley Tuff}

The Redrock Valley Tuff of the Volcanics of Oak Spring Butte is exposed in the western and northern portions of Yucca Flat. It is also sporadically present in the subsurface of central and eastern Yucca Flat, where its presence and thickness seem to be related to paleotopography (i.e., more likely to be present and thicker in paleovalleys). West of Yucca Flat, the Redrock Valley Tuff is a calc-alkaline, partially to densely welded, rhyolitic ash-flow tuff (Figure 4-15). In the subsurface of central and eastern Yucca Flat, it is nonwelded to partially welded, zeolitic to devitrified (Table 2-2). Its pastel coloring and devitrified nature (within zeolitic rocks) are also distinctive (Figure 4-16). In the Tuff Pile area, the Redrock Valley ash-flow tuff is only recognized in Exploratory Hole UE-4f, where it is about $13.7 \mathrm{~m}$ (45 ft) thick and poorly welded.

\subsubsection{Tuff of Twin Peaks}

The tuff of Twin Peaks (previously called Fraction Tuff) of the Volcanics of Oak Spring Butte is exposed along the northern margin of Yucca Flat. West of the Eleana Range it is commonly seen as a partially to densely welded ash-flow tuff, but in Yucca Flat it is a nonwelded to partially welded, simple cooling unit. The tuff is light gray to medium brown in color and crystal-rich (Table 2-2). It is distinctive because the tuff is lithic-rich, incorporating fragments of lava flows, gneiss, schist, granite, and sedimentary rocks. The unit is typically poorly welded and zeolitic (Figures 4-17 and 4-18). The tuff of Twin Peaks is recognized in four holes in the Tuff Pile area and ranges from totally absent to $51.8 \mathrm{~m}$ (170 ft) thick (Appendix A). 


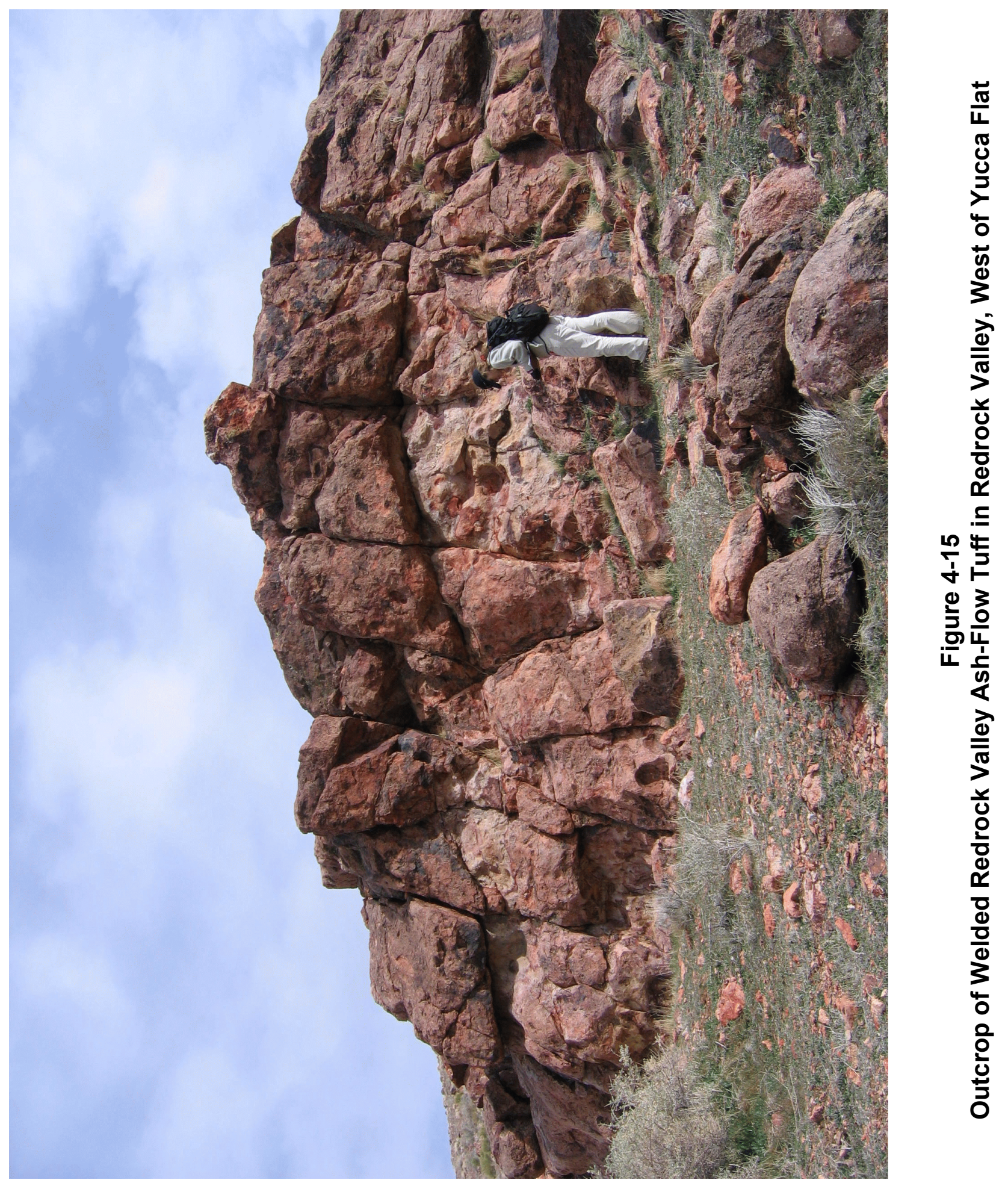



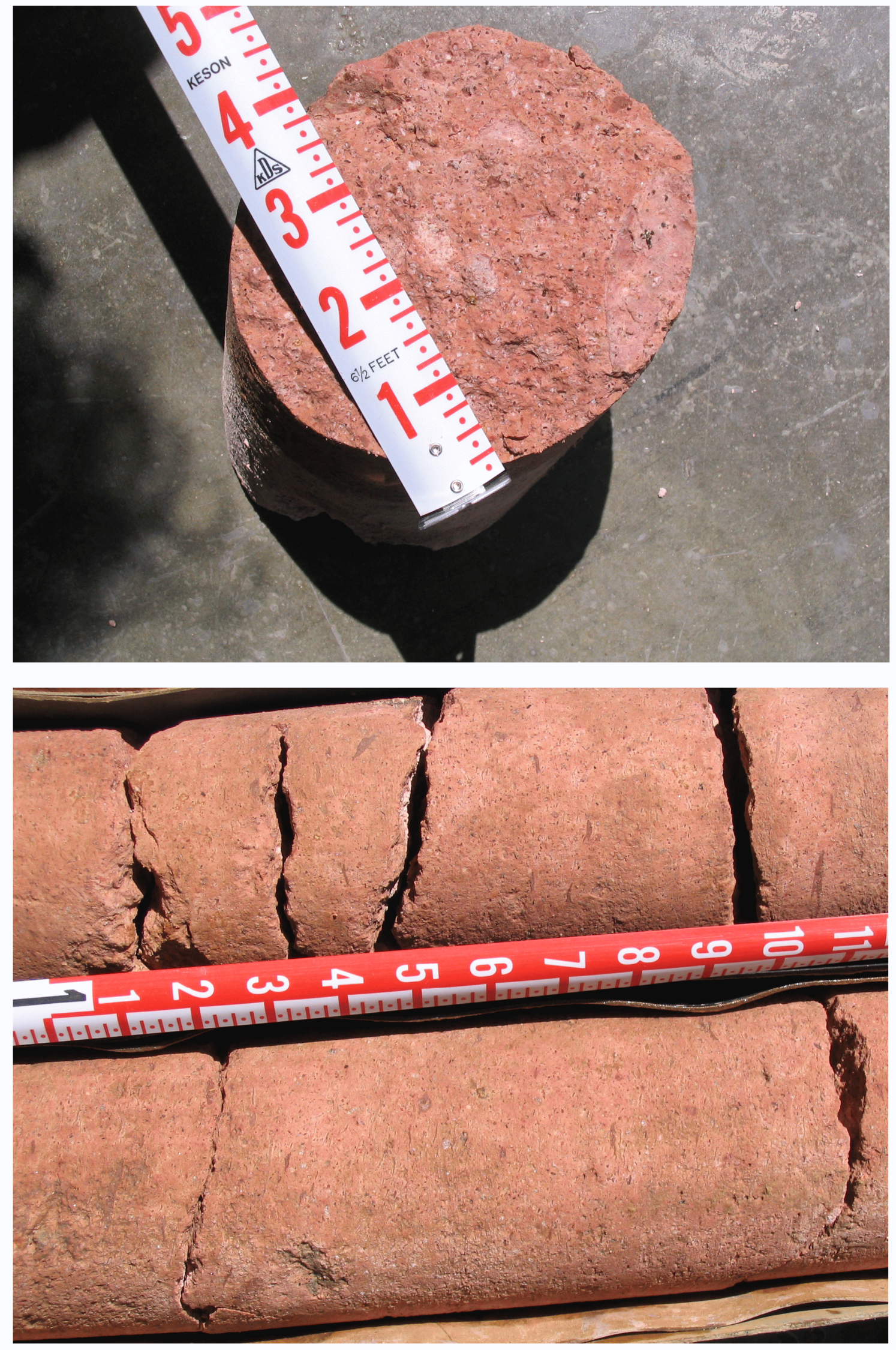

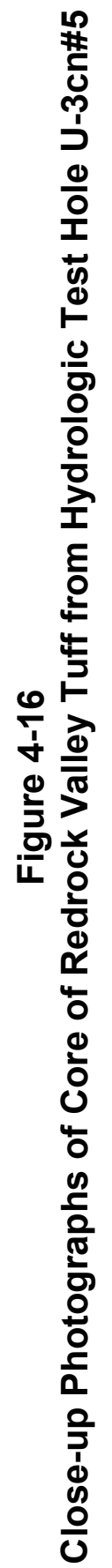




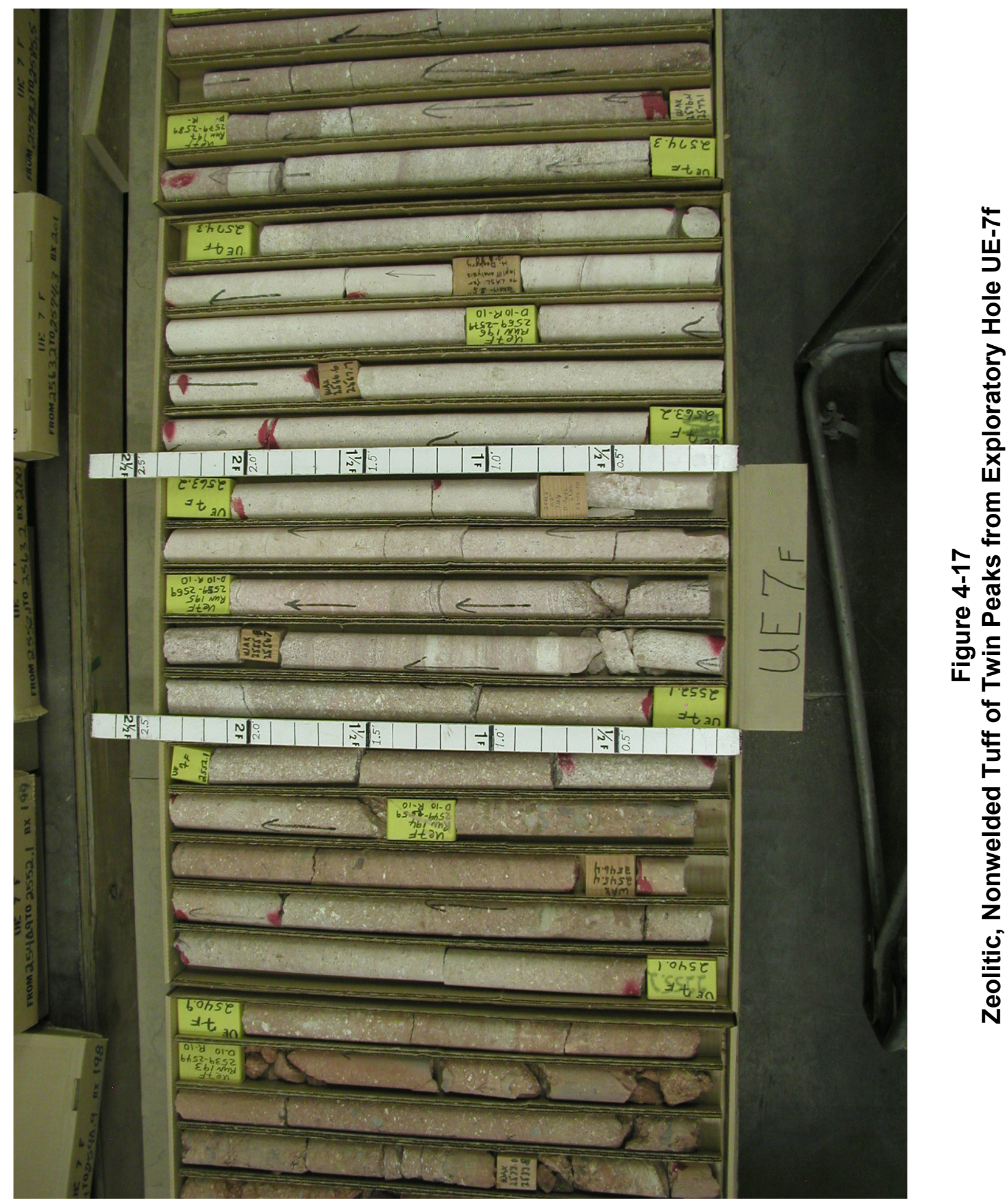



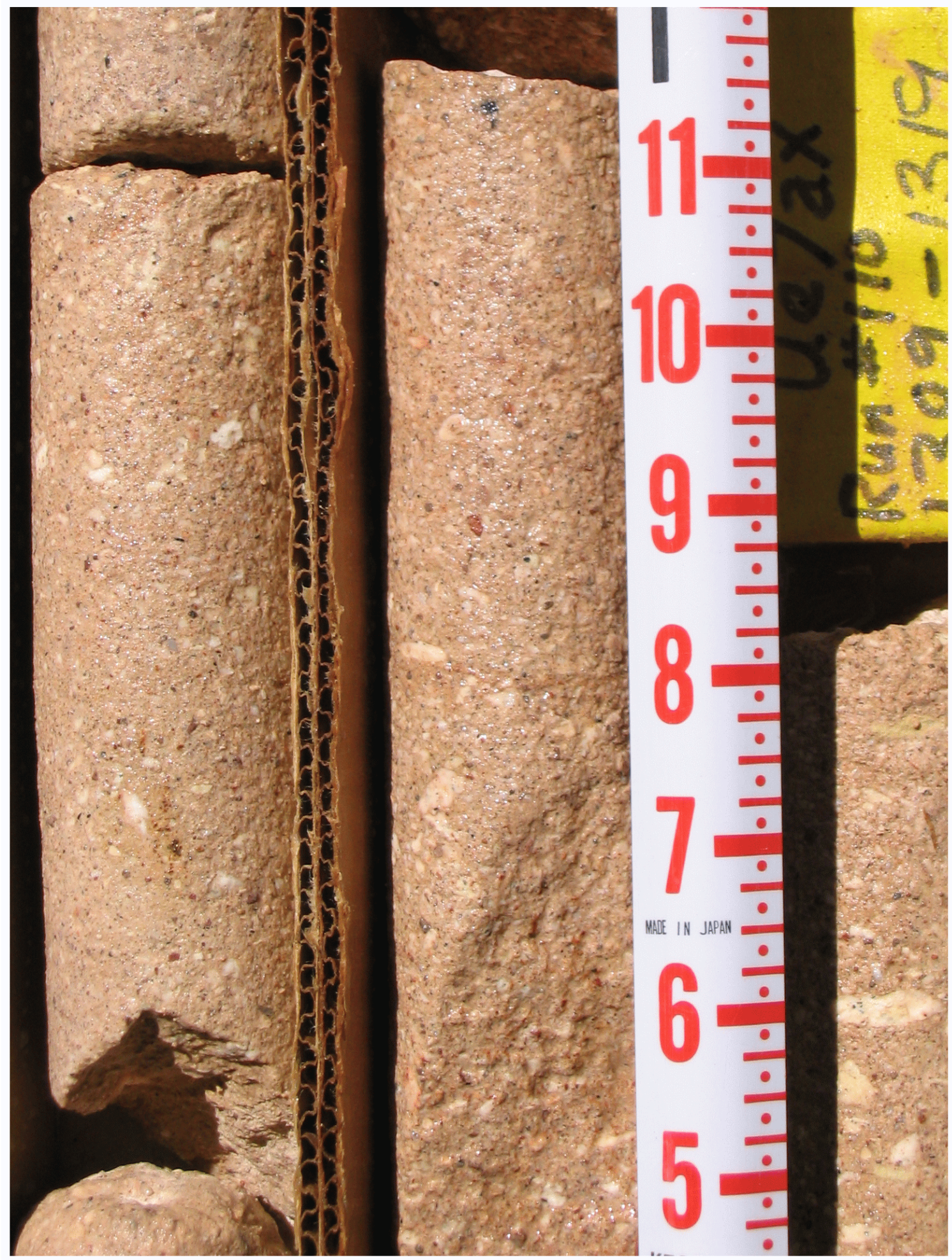

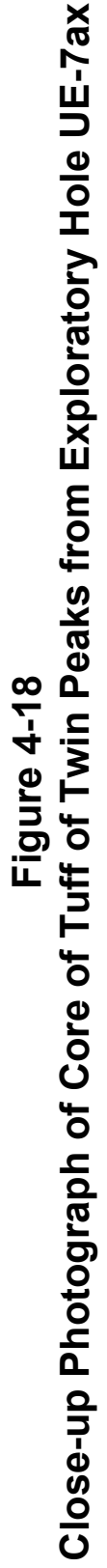


This page intentionally left blank.

4-28 


\subsection{Summary and Conclusion}

No welded ash-flow tuff units (i.e., WTAs), with their characteristic low-porosity, highpermeability (i.e., highly fractured) properties, are present within the zeolitized tuff section of the Tuff Pile area of central Yucca Flat. Detailed examination of continuous core holes clearly shows the absence of strongly welded tuff units below the Timber Mountain Group. The absence of welded tuff units is also corroborated by the nearly continuous record available from numerous wireline geophysical logs and published physical properties databases. Taken together, these data substantially reduce uncertainty that welded units were somehow not recognized during geologic investigations conducted in the area over the last 30 years.

The three HSUs that make up the altered tuff section in the UGTA YF-CM HFM, the LTCU, OSBCU, and ATCU, were defined to permit flexibility for modelers to vary properties within the hydrologically important section of tuffs that overlie the LCA. However, abundant geologic, mineralogic, and physical properties data that are available for the Tuff Pile area show that below the level of pervasive zeolitization, only high-porosity, zeolitic (including minor quartzofeldspathic) tuff units are present. Low porosity values that are characteristic of WTAs are not observed in rocks below the level of pervasive zeolitization (e.g., within the LTCU and OSBCU). Mineralogic data show a fairly persistent high level of zeolitization for the LTCU and OSBCU. Dense, devitrified, non-zeolitic, highly fractured units characteristic of WTAs are absent.

It is recognized that partially welded ash-flow tuffs are present within the OSBCU (described in $\mathrm{BN}, 2006$ ) as noted here, and that these units may present the possibility for slightly greater conductivity. However, the authors must emphasize that these units are not the same fractured, high-conductivity units categorized as WTA in the HFMs.

Though the Tuff Pile sub-CAU-scale modeling task documented in Boryta et al. (in review) may have yielded useful information and hydrogeologic insights, the inclusion of low-porosity, highpermeability units within the LTCU should not be perpetuated. Furthermore, the inclusion of such welded tuff units within the LTCU should not be carried over to the CAU-scale YF-CM HFM. 
This page intentionally left blank.

$5-2$ 


\subsection{References}

App, F. N., and N. L. Marusak, 1983. A Justification for the Projection of Material Properties within a Portion of Los Alamos Test Areas 1, 3, 4, and 7 - Nevada Test Site. Los Alamos National Laboratory Report ESS-CPO-83-22, Los Alamos, NM.

App, F. N., and N. L. Marusak, 1997. Tuff Pile 1 - A Justification for the Projection of Material Properties within a Portion of Los Alamos Test Areas 1, 3, 4, and 7, Nevada Test Site. LA-UR-97-1024. Los Alamos National Laboratory, Los Alamos, NM.

Bechtel Nevada, 2002. A Hydrostratigraphic Model and Alternatives for the Groundwater Flow and Contaminant Transport Model of Corrective Action Units 101 and 102: Central and Western Pahute Mesa, Nye County, Nevada. DOE/NV/11718--706. Las Vegas, NV.

Bechtel Nevada, 2005. A Hydrostratigraphic Model and Alternatives for the Groundwater Flow and Contaminant Transport Model of Corrective Action Unit 98: Frenchman Flat, Clark, Lincoln, and Nye County, Nevada. DOE/NV/11718--1064. Las Vegas, NV.

Bechtel Nevada, 2006. A Hydrostratigraphic Model and Alternatives for the Groundwater Flow and Contaminant Transport Model of Corrective Action Unit 97: Yucca Flat-Climax Mine, Lincoln and Nye Counties, Nevada. DOE/NV/11718--1119. Las Vegas, NV.

Blankennagel, R. K., and J. E. Weir, Jr., 1973. Geohydrology of the Eastern Part of Pahute Mesa, Nevada Test Site, Nye County, Nevada. U.S. Geological Survey Professional Paper 712-B, 35 pp. Washington, D.C.

Boryta, J., E. Keating, A. Wolfsberg, P. Stauffer, C. Gable, and S. Kelkar, in review. Analysis and Evaluation of Elevated Groundwater Heads and Their Impact on Flow and Solute Transport in the Tuff Pile: Areas 3, 4, and 7 of the Nevada Test Site, Nye County, Nevada. Los Alamos National Laboratory, Los Alamos, NM.

Brethauer, G. E., J. E. Magner, and D. R. Miller, 1980. Statistical Evaluation of Physical Properties in Area 12, Nevada Test Site, Using the USGS/DNA Storage and Retrieval System. U.S. Geological Survey Special Projects-43, 96 pp. Denver, CO.

Carroll, R. D., 1990. Electric Logging and Electrical Properties of Rocks in Rainier Mesa Area, Nevada Test Site, Nevada. U.S. Geological Survey Open-File Report 90-31, 90 pp.

Cavazos, A. P., S. L. Drellack, Jr., W. T. Hughes, and P. H. Thompson, 1987. Lithology and Stratigraphy of Drill Holes Completed During 1986 in LANL Use Areas of Yucca Flat, Nevada Test Site. DOE/NV/10322-22, Fenix \& Scisson, Inc., Las Vegas, NV.

Davies, W. J., J. L. Gonzales, and S. L. Drellack, Jr., 1982. Lithologic and Geophysical Logs of Selected Drill Holes in Eastern Area 4 and Western Area 7, Nevada Test Site.

DOE/NV/10322-3, Fenix \& Scisson, Inc., Las Vegas, NV. 
Dickerson, R. P., T. P. Rose, and G. F. Eaton, 2004. Written communication. Subject: Underground Test Area Project, Mineralogical and Isotopic Analysis of Fracture-Coating and Alteration Minerals in the Yucca Flat Tuff Confining Unit, Nevada Test Site. StollerNavarro Joint Venture Letter Report, April 1, 2004. Las Vegas, NV.

DOE/NV, see U.S. Department of Energy, Nevada Operations Office.

Doty, G. C., and W. Thordarson, 1983. Water Table in Rocks of Cenozoic and Paleozoic Age, 1980, Yucca Flat, Nevada Test Site, Nevada, U.S. Geological Survey Water Resources Investigation Report 83-4067.

Drellack, S. L., Jr., 1994a. Written communication: Subject: Subsurface Geologic Maps of Southern Yucca Flat. Memorandum TSP:DGP:024:95 to Distribution. Raytheon Services Nevada, Las Vegas, NV.

Drellack, S. L., Jr., 1994b. Written communication. Subject: An Introduction to NTS Geology and Geophysical Log Characteristics. Raytheon Services Nevada, Las Vegas, NV. 68 pp.

Drellack, S. L., Jr., and P. H. Thompson, 1990. Selected Stratigraphic Data for Drill Holes in LANL Use Areas of Yucca Flat, Nevada Test Site. DOE/NV-10322-39. Fenix \& Scisson, Inc., Las Vegas, NV.

Drellack, S. L., Jr., W. J. Davies, and J. L. Gonzales, 1983. Lithologic and Geophysical Logs of Selected Drill Holes in Areas 3 and 7 and the Eastern Parts of Areas 1 and 4, Nevada Test Site. DOE/NV/10322-4, Fenix \& Scisson, Inc., Las Vegas, NV.

Drellack, S. L., Jr., J. L. Gonzales, and A. P. Cavazos, 1986. Lithology and Stratigraphy of Drill Holes Completed During 1985 in LANL Use Areas of Yucca Flat, Nevada Test Site. DOE/NV/10322-9, Fenix \& Scisson, Inc., Las Vegas, NV.

Fenelon, J. M., 2005. Analysis of Groundwater Levels and Associated Trends in Yucca Flat, Nevada Test Site, Nye County, Nevada, 1951-2003. U.S. Geological Survey Scientific Investigations Report 2005-5175, 88 pp.

Ferguson, J. F., A. H. Cogbill, and R. G. Warren, 1994. "A Geophysical-Geological Transect of the Silent Canyon Caldera Complex, Pahute Mesa, Nevada." Journal of Geophysical Research, vol. 99, no. 33, pp. 4,323-4,339.

Hale, G. S., D. A. Trudeau, and C. S. Savard, 1995. Water-Level Data from Wells and Test Holes Through 1991, and Potentiometric Contours as of 1991 for Yucca Flat, Nevada Test Site, Nye County, Nevada, Water-Resources Investigations Report 95-4177, U.S. Geological Survey, Denver, CO.

Halford, K. J., R. J. Laczniak, and D. L. Galloway, 2005. Hydraulic Characterization of Overpressured Tuffs in Central Yucca Flat, Nevada Test Site, Nye County, Nevada. U.S. Geological Survey Investigations Report 2005-5211. 35 pp. 
Hawkins, W. L., A. P. Cavazos, and P. H. Thompson, 1988. "Geologic and Hydrologic Investigations at the Aleman (U3kz) site, and other sites in Yucca Flat, the Nevada Test Site." In: Olsen, C. W., M. L. Donahue, and S. W. Wanden, eds., Fourth Symposium on the Containment of Underground Nuclear Explosions, Proceedings, CONF 89-870961, vol. 2, pp. 387-398.

Hawkins, W. L., D. A. Trudeau, and T. M. Mihevc, 1989. "Hydrologic Testing in Exploratory Drill Hole UE4t, Yucca Flat, the Nevada Test Site.” In: Olsen, C. W., and J. A. Carter, eds., Proceedings, Fifth Symposium on Containment of Underground Nuclear Explosions, Santa Barbara, California, September 19-22, 1989. Lawrence Livermore National Laboratory, CONF-8909163, vol. 2, pp. 141-159. Livermore, CA.

Hoover, D. L. 1968. “Genesis of Zeolites.” In: Eckel, E. B., ed., Nevada Test Site, Memoir 110, pp. 275-284, Boulder, CO: The Geological Society of America, Inc.

International Technologies Corporation, 1996a. Regional Geologic Model Data Documentation Package (Phase I, Data Analysis Documentation, Volume I, Parts 1 and 2). ITLV/10972--181. Las Vegas, NV.

International Technologies Corporation, 1996b. Potentiometric Data Task Documentation Package (Phase I, Data Analysis Documentation, Vol. II). ITLV/10972--181. Las Vegas, NV.

IT, see International Technologies Corporation.

Laczniak, R. J., J. C. Cole, D. A. Sawyer, and D. A. Trudeau, 1996. Summary of Hydrogeologic Controls on the Ground-water Flow at the Nevada Test Site, Nye County, Nevada. U.S. Geological Survey Water Resources Investigation Report 96-4109, Carson City, NV.

National Security Technologies, LLC, 2007. A Hydrostratigraphic Model and Alternatives for the Groundwater Flow and Contaminant Transport Model of Corrective Action Unit 99: Rainier Mesa-Shoshone Mountain, Nye County, Nevada. DOE/NV/25946--146. Las Vegas, NV.

Nevada Bureau of Mines and Geology, 1996. County Digital Geologic Mapping Project - Final Report. Open-File Report 97-1, scale 1:250,000.

Prothro, L. B., 2005. Mineralogic Zonation Within the Tuff Confining Unit, Yucca Flat, Nevada Test Site. DOE/NV/11718--995. Bechtel Nevada, Las Vegas, NV.

Prothro, L. B., 2008. Analysis of Fractures in Cores from the Tuff Confining Unit beneath Yucca Flat, Nevada Test Site. DOE/NV/25946--351. National Security Technologies, LLC, Las Vegas, NV.

Prothro, L. B., and S. L. Drellack, Jr., 1997. Review and Reconnaissance of the Hydrogeology of Tertiary Sedimentary Rocks in the Vicinity of Frenchman Flat, Nevada Test Site. DOE/NV/11718--155. Bechtel Nevada, Las Vegas, NV. 
Prothro, L. B., Drellack, S. L., and B. M. Allen, 1999. Lithology and Stratigraphy of Holes Drilled in LANL Use Areas of the Nevada Test Site 1991-1998. DOE/NV/11718--254. Bechtel Nevada, Las Vegas, NV.

Prothro, L. B., S. L. Drellack, Jr., and J. M. Mercadante, 2009. A Hydrostratigraphic System for Modeling Groundwater Flow and Radionuclide Migration at the Corrective Action Unit Scale, Nevada Test Site and Surrounding Areas, Clark, Lincoln, and Nye Counties, Nevada. DOE/NV/25946--630. National Security Technologies, LLC, Las Vegas, NV.

Sawyer, D. A., R. J. Fleck, M. A. Lanphere, R. G. Warren, D. E. Broxton, and M. R. Hudson, 1994. "Episodic Caldera Volcanism in the Miocene Southwest Nevada Volcanic Field: Revised Stratigraphic Framework, ${ }^{40} \mathrm{Ar} /{ }^{39} \mathrm{Ar}$ Geochronology and Implications for Magmatism and Extension." Geological Society of America Bulletin, vol. 106, pp. 1,304-1,318.

Slate, J. L., M. E. Berry, P. D. Rowley, C. J. Fridrich, K. S. Morgan, J. B. Workman, O. D. Young, G. L. Dixon, V. S. Williams, E. H. McKee, D. A. Ponce, T. G. Hildenbrand, WC Swadley, S. C. Lundstrom, E. B. Ekren, R. G. Warren, J. C. Cole, R. J. Fleck, M. A. Lanphere, D. A. Sawyer, S. A. Minor, D. J. Grunwald, R. J. Laczniak, C. M. Menges, J. C. Yount, and A. S. Jayko, 1999. Digital Geologic Map of the Nevada Test Site and Vicinity, Nye, Lincoln, and Clark Counties, Nevada and Inyo County, California.

U.S. Geological Survey Open-File Report 99-554-A, scale 1:120,000.

SNJV, see Stoller-Navarro Joint Venture.

Stoller-Navarro Joint Venture, 2007. Phase I Contaminant Transport Parameters for the Groundwater Flow and Transport Model of CAU 97: Yucca Flat-Climax Mine, Nye County, Nevada, Technical Report S-N/99205--096, Las Vegas, NV.

Thompson, J. L., ed., 1991. Interim Report of the Drilling History and Analysis for Nevada Test Site Hole UE3e\#4, LA-UR-12042-MS. Los Alamos National Laboratory, Los Alamos, NM.

Thordarson, W., 1965. Perched Groundwater in Zeolitized-Bedded Tuff, Rainier Mesa and Vicinity, Nevada Test Site, Nevada. U.S. Geological Survey Report TEI-862, 90 pp.

U.S. Department of Energy, Nevada Operations Office, 1997. Regional Groundwater Flow and Tritium Transport Modeling and Risk Assessment of the Underground Test Area, Nevada Test Site, Nevada. DOE/NV--477. Las Vegas, NV.

U.S. Department of Energy, Nevada Operations Office, 2000. United States Nuclear Tests, July 1945 through September 1992, Report No. DOE/NV--209 (Rev. 15).

Warren, R. G., D. A. Sawyer, F. M. Byers, Jr., and J. C. Cole, 2003. A Petrographical, Geochemical and Geophysical Database and Framework for the Southwestern Nevada Volcanic Field. LA-UR-03-1503. Los Alamos National Laboratory, Los Alamos, NM.

Winograd, I. J., and W. Thordarson, 1975. Hydrogeologic and Hydrochemical Framework South-Central Great Basin, Nevada-California, with Special Reference to the Nevada Test Site. U.S. Geological Survey Professional Paper 712-C, 126 pp. Washington, D.C. 
Wohletz, K. A., and W. L. Hawkins, 1998. Effects of Underground Nuclear Testing Below the Water Table on Groundwater and Radionuclide Migration in Areas 1, 3, 4, and 7 ("Tuff Pile 1"), Yucca Flat, Nevada Test Site. EES UGTA FY98 Report, Los Alamos National Laboratory, $22 \mathrm{pp}$.

Wohletz, K., A. Wolfsberg, A. Olson, and C. Gable, 1999. Evaluating the Effects of Underground Nuclear Testing Below the Water Table on Groundwater and Radionuclide Migration in the Tuff Pile I Region of Yucca Flat-Numerical Simulations. EES UGTA FY99 Report, Los Alamos National Laboratory, 31 pp.

Wood, D. B., 2007. Digitally Available Interval-Specific Rock Sample Data Compiled from Historical Records, Nevada Test Site and Vicinity, Nye County, Nevada. U.S. Geological Survey Data Series 297, version 2.0, revised October 2009. Denver, CO.

Zavarin M., S. F. Carle, and R. M. Maxwell, 2004. Upscaling Radionuclide RetardationLinking the Surface Complexation and Ion Exchange Mechanistic Approach to a Linear $K_{d}$ Approach. Lawrence Livermore National Laboratory Report UCRL-TR-204713, Livermore, CA. 
This page intentionally left blank. 


\section{APPENDIX A}

Stratigraphic Data for Boreholes in the Tuff Pile Area 
This page intentionally left blank. 
Table A-1

Stratigraphic Data for Boreholes in the Tuff Pile Area

(datum in feet)

\begin{tabular}{|c|c|c|c|c|c|c|c|c|}
\hline \multirow{2}{*}{ Stratigraphic Unit ${ }^{1}$} & \multicolumn{8}{|c|}{ Borehole } \\
\hline & UE1q & UE3b & UE3e & UE3e\#2 & UE3e\#4 & U 3gg & U 3gv & U $3 \mathbf{k z}$ \\
\hline Tma & 1278 & 4110 & 930 & 940 & 925 & 680 & 960 & 940 \\
\hline Tmab & 1340 & $\mathrm{nd}^{6}$ & 1180 & 1190 & 1180 & 950 & nd & 1185 \\
\hline Tmr & 1347 & 610 & 1200 & 1210 & 1200 & 970 & 1220 & 1205 \\
\hline Tmrh & 1755 & -- & 1685 & 1695 & 1685 & 1450 & -- & 1700 \\
\hline Tpc & nd & -- & nd & nd & nd & nd & - & nd \\
\hline Tpt & nd & -- & nd & nd & nd & nd & -- & nd \\
\hline Th & nd & -- & nd & nd & 1900 & nd & -- & nd \\
\hline Twlb & 1900 & -- & 1990 & 1984 & 1980 & 1840 & -- & 2000 \\
\hline Tc & 1955 & -- & 2075 & 2095 & 2075 & 1950 & -- & 2080 \\
\hline Tcb & nd & -- & nd & 2191 & -- & nd & -- & nd \\
\hline Tbgb & 2065 & -- & none & none & -- & none & -- & -- \\
\hline Tn4 & 2085 & -- & 2330 & 2364 & -- & 2205 & -- & -- \\
\hline Tn4E & nd & -- & -- & -- & -- & -- & -- & -- \\
\hline Tn3 & nd & -- & -- & -- & -- & -- & -- & -- \\
\hline Tn3BC & nd & -- & -- & -- & -- & -- & -- & -- \\
\hline Tub & nd & -- & -- & -- & $\overline{--}$ & -- & -- & -- \\
\hline Ton2 & nd & -- & -- & -- & -- & -- & -- & -- \\
\hline Toy & nd & -- & -- & -- & -- & -- & -- & -- \\
\hline Ton1 & nd & -- & -- & -- & -- & -- & -- & -- \\
\hline Tor & nd & -- & -- & -- & -- & -- & -- & -- \\
\hline To2 & nd & -- & -- & -- & -- & - & - & - \\
\hline Tot & nd & -- & -- & -- & -- & -- & -- & -- \\
\hline To1 & nd & -- & -- & -- & -- & -- & -- & -- \\
\hline TIC & 2330 & -- & -- & -- & -- & -- & -- & -- \\
\hline $\mathrm{Pz}$ & 2350 & -- & -- & -- & -- & -- & -- & -- \\
\hline Total Depth & 2600 & 780 & 2510 & 2372 & 2300 & 2250 & 1477 & 2250 \\
\hline Surface Elevation ${ }^{2}$ & 4082 & 4080 & 4083 & 4081 & 4083 & 4079 & 4057 & 4085 \\
\hline Year Drilled & 92 & 76 & 86 & 87 & 90 & 83 & 79 & 84 \\
\hline Northing, feet ${ }^{3}$ & 841500 & 843700 & 844898 & 844938 & 844888 & 843499 & 840000 & 844700 \\
\hline Easting, feet $^{3}$ & 677500 & 682000 & 679984 & 679983 & 680001 & 681000 & 680500 & 680001 \\
\hline Diameter, inches ${ }^{4}$ & 6.75 & 4.75 & 9.88 & 3.94 & 12.25 & 86.00 & 52.00 & 96.00 \\
\hline Static Water Level & 1656 & -- & 1522 & 517 & 1108 & 1630 & -- & 1431 \\
\hline Depth to Zeol ${ }^{5}$ & 1800 & -- & 1685 & 1685 & 1630 & 1445 & -- & 1700 \\
\hline Tmr vit depth & 1533 & -- & none & none & none & 1085 & 1340 & 1440 \\
\hline
\end{tabular}


Table A-1

Stratigraphic Data for Boreholes in the Tuff Pile Area

(datum in feet)

\begin{tabular}{|c|c|c|c|c|c|c|c|c|}
\hline \multirow{2}{*}{ Stratigraphic Unit ${ }^{1}$} & \multicolumn{8}{|c|}{ Borehole } \\
\hline & U 3la & U 3lj & UE3lj & U 3lo & U 3Ir & U $3 \mathrm{mf}$ & UE3mf & U $3 m t$ \\
\hline Tma & 600 & 958 & 1015 & 745 & 725 & 680 & 680 & 635 \\
\hline Tmab & 843 & -- & 1205 & 965 & 940 & 920 & 920 & 885 \\
\hline $\mathrm{Tmr}$ & 850 & -- & 1235 & 980 & 960 & 950 & 945 & 908 \\
\hline Tmrh & 1350 & -- & 1722 & -- & 1460 & 1430 & 1430 & 1375 \\
\hline Tpc & nd & -- & nd & -- & -- & nd & nd & -- \\
\hline$\overline{T p t}$ & nd & -- & nd & -- & -- & nd & nd & -- \\
\hline Th & nd & -- & nd & -- & -- & nd & nd & -- \\
\hline Twlb & 1725 & -- & 1975 & -- & -- & 1780 & 1780 & -- \\
\hline Tc & 1800 & -- & 2055 & -- & -- & 1875 & 1870 & -- \\
\hline Tcb & nd & -- & nd & -- & -- & nd & nd & -- \\
\hline Tbgb & 2005 & -- & 2240 & -- & -- & 2075 & 2075 & -- \\
\hline Tn4 & 2035 & -- & 2260 & -- & -- & 2085 & 2080 & -- \\
\hline Tn4E & -- & -- & nd & -- & -- & -- & -- & -- \\
\hline Tn3 & -- & -- & 2410 & -- & -- & -- & -- & -- \\
\hline Tn3BC & -- & -- & nd & -- & -- & -- & -- & -- \\
\hline Tub & -- & -- & nd & -- & -- & -- & $\overline{--}$ & -- \\
\hline Ton2 & -- & -- & nd & -- & -- & -- & -- & -- \\
\hline Toy & -- & -- & nd & -- & -- & -- & -- & -- \\
\hline Ton1 & -- & -- & nd & -- & -- & -- & -- & -- \\
\hline Tor & -- & -- & nd & -- & -- & -- & -- & -- \\
\hline To2 & -- & -- & nd & -- & -- & -- & -- & -- \\
\hline Tot & -- & -- & 2725 & -- & -- & -- & -- & -- \\
\hline To1 & -- & -- & 2890 & -- & -- & -- & -- & -- \\
\hline TIC & -- & -- & 2930 & -- & -- & -- & -- & -- \\
\hline $\mathbf{P z}$ & -- & -- & 2958 & -- & -- & -- & -- & -- \\
\hline Total Depth & 2250 & 1100 & 3080 & 1000 & 1500 & 2200 & 2395 & 1550 \\
\hline Surface Elevation ${ }^{2}$ & 4083 & 4062 & 4068 & 4058 & 4057 & 4061 & 4061 & 4067 \\
\hline Year Drilled & 79 & 80 & 81 & 82 & 84 & 86 & 86 & 90 \\
\hline Northing, feet ${ }^{3}$ & 844700 & 840700 & 841848 & 840000 & 840700 & 841751 & 841716 & 842650 \\
\hline Easting, feet ${ }^{3}$ & 681235 & 680499 & 680141 & 681300 & 681300 & 681300 & 681319 & 681300 \\
\hline Diameter, inches ${ }^{4}$ & 64.00 & 96.00 & 12.25 & 96.00 & 96.00 & 96.00 & 12.25 & 96.00 \\
\hline Static Water Level & $\mathrm{nm}^{7}$ & -- & $\mathrm{nm}$ & -- & -- & $\mathrm{nm}$ & 1440 & -- \\
\hline Depth to Zeol ${ }^{5}$ & 1350 & -- & 1722 & -- & 1480 & 1425 & 1405 & 1372 \\
\hline Tmr vit depth & 970 & -- & 1360 & -- & 1080 & 1150 & 1150 & 1025 \\
\hline
\end{tabular}


Table A-1

Stratigraphic Data for Boreholes in the Tuff Pile Area

(datum in feet)

\begin{tabular}{|c|c|c|c|c|c|c|c|c|}
\hline \multirow{2}{*}{ Stratigraphic Unit ${ }^{1}$} & \multicolumn{8}{|c|}{ Borehole } \\
\hline & U 4b & UE4b & UE4c & U 4f & UE4f & $\mathbf{U} \mathbf{4 j}$ & U 4l & $\mathrm{U} 4 \mathrm{~m}$ \\
\hline Tma & 7774 & none & none & 965 & 950 & 762 & 900 & 970 \\
\hline Tmab & nd & none & 1195 & 1105 & 1115 & 905 & 1010 & nd \\
\hline Tmr & nd & 1322 & 1219 & 1130 & 1145 & 930 & 1030 & 1120 \\
\hline Tmrh & nd & 1467 & 1430 & 1595 & 1600 & 1370 & 1470 & 1605 \\
\hline Tpc & nd & nd & nd & nd & nd & nd & nd & nd \\
\hline Tpt & nd & nd & nd & nd & nd & nd & nd & nd \\
\hline Th & nd & nd & nd & nd & nd & nd & nd & nd \\
\hline Twlb & nd & 1750 & none & 1850 & 1840 & 1685 & 1655 & -- \\
\hline Tc & nd & 1775 & nd & 1895 & 1855 & 1730 & 1710 & -- \\
\hline Tcb & nd & nd & nd & nd & nd & nd & nd & -- \\
\hline Tbgb & 1610 & 1939 & none & 2165 & 2125 & 1840 & 1980 & -- \\
\hline Tn4 & -- & 1973 & none & 2195 & 2155 & 1875 & 2040 & -- \\
\hline Tn4E & -- & nd & none & -- & 2370 & 2065 & nd & -- \\
\hline Tn3 & -- & nd & 1532 & -- & 2455 & 2090 & -- & -- \\
\hline Tn3BC & -- & nd & nd & -- & 2495 & nd & -- & -- \\
\hline Tub & -- & nd & 1720 & -- & nd & -- & -- & -- \\
\hline Ton2 & -- & nd & 1770 & -- & nd & -- & -- & -- \\
\hline Toy & -- & nd & none & -- & nd & -- & -- & -- \\
\hline Ton1 & -- & nd & 1810 & -- & nd & -- & -- & -- \\
\hline Tor & -- & nd & nd & -- & 3005 & -- & -- & -- \\
\hline To2 & -- & nd & nd & -- & 3050 & -- & -- & -- \\
\hline Tot & -- & nd & nd & -- & 3140 & -- & -- & -- \\
\hline To1 & -- & nd & nd & -- & 3185 & -- & -- & -- \\
\hline TIC & -- & nd & 1950 & -- & 3465 & -- & -- & -- \\
\hline $\mathrm{Pz}$ & -- & 2845 & 1964 & -- & 3515 & -- & - & -- \\
\hline Total Depth & 1640 & 3153 & 2040 & 2340 & 3593 & 2250 & 2331 & 1639 \\
\hline Surface Elevation $^{2}$ & 4145 & 4131 & 4162 & 4129 & 4129 & 4134 & 4159 & 4129 \\
\hline Year Drilled & 63 & 80 & 81 & 77 & 78 & 81 & 78 & 79 \\
\hline Northing, feet ${ }^{3}$ & 854362 & 849738 & 854749 & 851500 & 851591 & 852801 & 856850 & 851434 \\
\hline Easting, feet ${ }^{3}$ & 679638 & 676589 & 676575 & 679100 & 679126 & 679499 & 678420 & 678987 \\
\hline Diameter, inches ${ }^{4}$ & 42.00 & 9.88 & 8.75 & 64.00 & 9.88 & 86.00 & 64.00 & 64.00 \\
\hline Static Water Level & $\mathrm{nm}$ & $\mathrm{nm}$ & $\mathrm{nm}$ & 1663 & $\mathrm{~nm}$ & $\mathrm{~nm}$ & $\mathrm{~nm}$ & $\mathrm{~nm}$ \\
\hline Depth to Zeol ${ }^{5}$ & nd & nd & 1450 & 1520 & 1560 & 1345 & 1580 & nd \\
\hline Tmr vit depth & nd & nd & 1260 & 1250 & nd & 1045 & 1160 & nd \\
\hline
\end{tabular}


Table A-1

Stratigraphic Data for Boreholes in the Tuff Pile Area

(datum in feet)

\begin{tabular}{|c|c|c|c|c|c|c|c|c|}
\hline \multirow{2}{*}{ Stratigraphic Unit ${ }^{1}$} & \multicolumn{8}{|c|}{ Borehole } \\
\hline & U 4n & U 4r & U 4s & $\mathbf{U} 4 \mathrm{u}$ & U 4u\#1 & U 7an & U 7ap & U 7aq \\
\hline Tma & 970 & 1020 & 1205 & 660 & 675 & 340 & 238 & 955 \\
\hline Tmab & 1100 & 1210 & 1460 & 785 & nd & 550 & 350 & 1205 \\
\hline Tmr & 1120 & 1225 & 1475 & 815 & 825 & 560 & 375 & 1220 \\
\hline Tmrh & 1600 & 1730 & 1985 & 1290 & 1300 & 1070 & 870 & 1700 \\
\hline Tpc & nd & nd & -- & nd & nd & nd & nd & nd \\
\hline Tpt & nd & nd & -- & nd & nd & nd & nd & nd \\
\hline Th & nd & nd & -- & nd & nd & nd & nd & nd \\
\hline Twlb & 1860 & 1960 & -- & 1605 & 1615 & 1465 & 1110 & 2000 \\
\hline Tc & 1905 & 2015 & -- & 1655 & -- & 1520 & 1165 & 2090 \\
\hline Tcb & nd & nd & -- & nd & -- & nd & nd & nd \\
\hline Tbgb & 2165 & -- & -- & 1760 & -- & 1680 & none & 2280 \\
\hline Tn4 & 2195 & -- & -- & 1790 & -- & 1710 & 1345 & 2310 \\
\hline Tn4E & -- & -- & -- & 1990 & -- & 1890 & 1460 & 2530 \\
\hline Tn3 & -- & -- & -- & 2075 & -- & 2050 & 1610 & 2620 \\
\hline Tn3BC & -- & -- & -- & 2125 & -- & nd & nd & nd \\
\hline Tub & -- & -- & -- & -- & -- & none & nd & 2790 \\
\hline Ton2 & -- & -- & -- & -- & -- & 2283 & nd & 2800 \\
\hline Toy & -- & -- & -- & -- & -- & nd & 1910 & nd \\
\hline Ton1 & -- & -- & -- & -- & -- & 2350 & -- & 2920 \\
\hline Tor & -- & -- & -- & -- & -- & nd & -- & nd \\
\hline To2 & -- & -- & -- & -- & -- & nd & $\overline{--}$ & nd \\
\hline Tot & -- & -- & -- & -- & -- & 2775 & -- & 3140 \\
\hline To1 & -- & -- & -- & -- & -- & none & -- & 3310 \\
\hline TIC & -- & -- & -- & -- & -- & 2915 & -- & 3440 \\
\hline $\mathrm{Pz}$ & -- & -- & -- & -- & -- & -- & - & 3560 \\
\hline Total Depth & 2200 & 2250 & 2000 & 2200 & 1646 & 3161 & 2050 & 3620 \\
\hline Surface Elevation ${ }^{2}$ & 4130 & 4119 & 4125 & 4120 & 4120 & 4100 & 4148 & 4094 \\
\hline Year Drilled & 79 & 84 & 85 & 87 & 88 & 76 & 76 & 77 \\
\hline Northing, feet ${ }^{3}$ & 851622 & 850572 & 850800 & 851951 & 851967 & 847000 & 853900 & 845800 \\
\hline Easting, feet ${ }^{3}$ & 679054 & 679055 & 678375 & 680079 & 680051 & 681700 & 681350 & 679901 \\
\hline Diameter, inches ${ }^{4}$ & 64.00 & 86.00 & 96.00 & 96.00 & 12.25 & 64.00 & 64.00 & 64.00 \\
\hline Static Water Level & 1663 & 1522 & $\mathrm{~nm}$ & $\mathrm{~nm}$ & -- & 1650 & 1650 & 1650 \\
\hline Depth to Zeol ${ }^{5}$ & nd & 1685 & 1950 & 1290 & nd & 1080 & 870 & 1840 \\
\hline Tmr vit depth & 1250 & 1440 & nd & nd & 940 & 600 & 500 & 1360 \\
\hline
\end{tabular}


Table A-1

Stratigraphic Data for Boreholes in the Tuff Pile Area

(datum in feet)

\begin{tabular}{|c|c|c|c|c|c|c|c|c|}
\hline \multirow{2}{*}{ Stratigraphic Unit ${ }^{1}$} & \multicolumn{8}{|c|}{ Borehole } \\
\hline & U 7au & U 7av & UE7b & U 7ba & UE7ba & UE7bj & U 7br & U $7 \mathrm{bu}$ \\
\hline Tma & 990 & 295 & 160 & 300 & 314 & 675 & 230 & $\overline{5990}$ \\
\hline Tmab & 1225 & 465 & nd & 400 & 410 & nd & 368 & 830 \\
\hline $\mathrm{Tmr}$ & 1280 & 480 & 220 & 425 & 440 & 745 & 385 & 840 \\
\hline Tmrh & 1730 & 1015 & -- & 898 & 912 & -- & 875 & 1345 \\
\hline Tpc & nd & nd & -- & nd & nd & -- & nd & nd \\
\hline$\overline{T p t}$ & nd & nd & -- & nd & nd & -- & nd & nd \\
\hline Th & nd & nd & -- & nd & nd & -- & nd & nd \\
\hline Twlb & 2015 & 1385 & -- & 1220 & 1237 & -- & 1170 & 1655 \\
\hline Tc & 2085 & 1435 & -- & 1275 & 1290 & -- & 1215 & 1690 \\
\hline Tcb & nd & nd & -- & nd & nd & -- & nd & nd \\
\hline Tbgb & 2300 & 1605 & -- & none & 1525 & -- & none & 1955 \\
\hline Tn4 & 2315 & 1635 & -- & 1534 & 1526 & -- & 1490 & 1985 \\
\hline Tn4E & nd & 1820 & -- & 1617 & 1629 & -- & 1535 & -- \\
\hline Tn3 & -- & -- & -- & 1750 & 1763 & -- & 1705 & -- \\
\hline Tn3BC & -- & -- & -- & 1825 & 1837 & -- & 1755 & -- \\
\hline Tub & -- & -- & -- & 1954 & 1967 & -- & 1900 & $\overline{--}$ \\
\hline Ton2 & -- & -- & -- & 1962 & 1975 & -- & 1910 & -- \\
\hline Toy & -- & -- & -- & -- & 2096 & -- & -- & -- \\
\hline Ton1 & -- & -- & -- & -- & 2201 & -- & -- & -- \\
\hline Tor & -- & -- & -- & -- & none & -- & -- & -- \\
\hline To2 & -- & - & -- & -- & nd & -- & -- & -- \\
\hline Tot & -- & -- & -- & -- & none & -- & -- & -- \\
\hline To1 & -- & -- & -- & -- & nd & -- & -- & -- \\
\hline TIC & -- & -- & -- & -- & 2382 & -- & -- & -- \\
\hline $\mathbf{P z}$ & -- & -- & -- & -- & 2396 & -- & -- & -- \\
\hline Total Depth & 2440 & 1938 & 262 & 2000 & 2428 & 812 & 2000 & 2000 \\
\hline Surface Elevation ${ }^{2}$ & 4111 & 4109 & 4153 & 4129 & 4130 & 4125 & 4137 & 4088 \\
\hline Year Drilled & 78 & 78 & 76 & 80 & 79 & 80 & 82 & 82 \\
\hline Northing, feet ${ }^{3}$ & 848600 & 848201 & 853698 & 851265 & 851264 & 852510 & 852799 & 846074 \\
\hline Easting, feet ${ }^{3}$ & 679500 & 681701 & 681900 & 681400 & 681350 & 680430 & 681350 & 681082 \\
\hline Diameter, inches $^{4}$ & 64.00 & 86.00 & 4.75 & 64.00 & 3.88 & 6.25 & 86.00 & 86.00 \\
\hline Static Water Level & $\mathrm{nm}$ & 1644 & -- & 1680 & $\mathrm{~nm}$ & -- & 1644 & $\mathrm{~nm}$ \\
\hline Depth to Zeol ${ }^{5}$ & 1615 & 1015 & -- & 898 & 909 & -- & 875 & 1345 \\
\hline Tmr vit depth & nd & 600 & -- & 543 & 557 & 808 & 485 & 955 \\
\hline
\end{tabular}


Table A-1

Stratigraphic Data for Boreholes in the Tuff Pile Area

(datum in feet)

\begin{tabular}{|c|c|c|c|c|c|c|}
\hline \multirow{2}{*}{ Stratigraphic Unit ${ }^{1}$} & \multicolumn{6}{|c|}{ Borehole } \\
\hline & UE7c & U 7cd & U 7cd\#1 & UE7d & UE7e & UE7f \\
\hline Tma & 310 & 379 & 363 & 100 & 295 & $\overline{560}$ \\
\hline Tmab & nd & 556 & 545 & nd & nd & 720 \\
\hline $\mathrm{Tmr}$ & -- & 576 & 563 & 150 & 472 & 750 \\
\hline Tmrh & -- & 1078 & 1074 & -- & -- & 1224 \\
\hline Tpc & -- & nd & nd & -- & -- & 1366 \\
\hline Tpt & -- & nd & nd & -- & -- & nd \\
\hline Th & -- & 1320 & 1309 & -- & -- & 1407 \\
\hline Twlb & -- & 1440 & 1427 & -- & -- & 1468 \\
\hline Tc & -- & 1510 & 1501 & -- & -- & 1509 \\
\hline Tcb & -- & -- & nd & -- & -- & nd \\
\hline Tbgb & -- & $\overline{--}$ & 1658 & $\overline{--}$ & -- & 1674 \\
\hline Tn4 & -- & -- & 1678 & -- & -- & 1704 \\
\hline Tn4E & -- & -- & -- & -- & -- & 1894 \\
\hline Tn3 & -- & -- & -- & -- & -- & 1999 \\
\hline Tn3BC & -- & -- & -- & -- & -- & 2047 \\
\hline Tub & -- & -- & -- & -- & -- & 2230 \\
\hline Ton2 & -- & -- & -- & -- & -- & 2239 \\
\hline Toy & -- & -- & -- & -- & -- & 2399 \\
\hline Ton1 & -- & -- & -- & -- & -- & 2415 \\
\hline Tor & -- & -- & -- & -- & -- & none \\
\hline To2 & -- & -- & -- & -- & -- & nd \\
\hline Tot & -- & -- & -- & -- & -- & 2560 \\
\hline To1 & -- & -- & -- & -- & -- & 2573 \\
\hline Tlc & -- & -- & -- & -- & -- & 2796 \\
\hline $\mathbf{P z}$ & -- & -- & -- & -- & -- & 2804 \\
\hline Total Depth & 343 & 1625 & 1700 & 298 & 482 & 2824 \\
\hline Surface Elevation ${ }^{2}$ & 4131 & 4115 & 4114 & 4138 & 4118 & 4124 \\
\hline Year Drilled & 76 & 92 & 92 & 76 & 76 & 80 \\
\hline Northing, feet ${ }^{3}$ & 851500 & 849000 & 849002 & 851500 & 849400 & 852510 \\
\hline${\text { Easting, } \text { feet }^{3}}^{3}$ & 681200 & 681400 & 681431 & 682400 & 681300 & 680180 \\
\hline Diameter, inches $^{4}$ & 2.98 & 96.00 & 12.25 & 2.98 & 2.98 & 2.98 \\
\hline Static Water Level & - & $\mathrm{nm}$ & $\mathrm{nm}$ & - & - & $\mathrm{nm}$ \\
\hline Depth to $\mathrm{Zeol}^{5}$ & -- & 1040 & 1029 & -- & - & 1199 \\
\hline Tmr vit depth & -- & 715 & 704 & nd & -- & 868 \\
\hline
\end{tabular}

\footnotetext{
1 See Tables 2-1 and 2-2 in the main body of this report for abbreviations

2 Surface elevation in feet

3 Northings and Eastings as Central NV State Planar coordinates, in feet; NAD 27

4 Diameter $=$ diameter of drill hole in inches

5 Depth to Zeol = Depth to top of zeolitization

6 nd $=$ unit not defined

$7 \mathrm{~nm}=$ not measured
} 


\section{Distribution List}

\section{Copies}

W. R. Wilborn

1 paper, $1 \mathrm{CD}$

U.S. Department of Energy

National Nuclear Security Administration

Nevada Site Office

Environmental Restoration Division

P.O. Box 98518, M/S 505

Las Vegas, NV 89193-8518

U.S. Department of Energy

1 paper (uncontrolled)

National Nuclear Security Administration

Nevada Site Office

Technical Library

P.O. Box 98518, M/S 505

Las Vegas, NV 89193-8518

U.S. Department of Energy

2 CDs (uncontrolled)

National Nuclear Security Administration

Nevada Site Office

Public Reading Facility

c/o Nuclear Testing Archive

P.O. Box 98521, M/S 400

Las Vegas, NV 89193-8521

U.S. Department of Energy

National Nuclear Security Administration

$1 \mathrm{CD}$ (uncontrolled)

Nevada Site Office

Northern Nevada Public Reading Facility

c/o Nevada State Library and Archives

100 North Stewart Street

Carson City, NV 89701-4285

U.S. Department of Energy

$1 \mathrm{CD}$ (uncontrolled)

Office of Scientific and Technical Information

P.O. Box 62

Oak Ridge, TN 37831-0061

Navarro-Intera Library

Navarro-Intera, LLC, NSF167

1 paper, $1 \mathrm{CD}$

P.O. Box 98518

232 Energy Way

Las Vegas, NV 89030 


\section{Copies}

N. M. Becker

1 paper, $1 \mathrm{CD}$

Los Alamos National Laboratory, EES-6

P. O. Pox 1663, MS T003

Building SM-30, Bikini Atoll Rd.

Los Alamos, NM 87545-1663

B. M. Crowe

1 paper, $1 \mathrm{CD}$

Navarro-Intera/Batelle

P. O. Box 98518, NSF167

232 Energy Way

Las Vegas, NV 89030

Elizabeth H. Keating

1 paper, $1 \mathrm{CD}$

Los Alamos National Laboratory, EES-6

P. O. Box 1663, MS T003

Building SM-30, Bikini Atoll Rd.

Los Alamos, NM 87545-1663

Edward M. Kwicklis

Los Alamos National Laboratory, EES-16

1 paper, $1 \mathrm{CD}$

P. O. Box 1663, MS T003

Building SM-30, Bikini Atoll Rd.

Los Alamos, NM 87545-1663

Sam Marutzky

UGTA Sub-Project Manager

Navarro-Intera, LLC, NSF167

P.O. Box 98518

Las Vegas, NV 89030

W. W. McNab

Lawrence Livermore National Laboratory

1 paper, $1 C D$

P.O. Box 808, L-231

Livermore, CA 94551-0808

P. K. Ortego

1 paper, $1 \mathrm{CD}$

National Security Technologies, LLC

1 paper, $1 \mathrm{CD}$

P.O. Box 98521, NLV082

Las Vegas, NV 89193-8521 


\section{Distribution List (continued)}

\section{Copies}

G. A. Pawloski

1 paper, $1 \mathrm{CD}$

Lawrence Livermore National Laboratory

P.O. Box 808, L-231

Livermore, CA 94551-0808

G. J. Ruskauff

Navarro-Intera, LLC, NSF167

1 paper, $1 \mathrm{CD}$

P.O. Box 98518

Las Vegas, NV 89030

C. E. Russell

1 paper, $1 \mathrm{CD}$

Desert Research Institute

755 E. Flamingo Road

Las Vegas, NV 89119-7363

B. K. Thompson

1 paper, $1 \mathrm{CD}$

Water Resources, Nevada District

U.S. Geological Survey

160 N. Stephanie Street

Henderson, NV 89074 
This page intentionally left blank.

Dist-4 


\section{PLATE 1}

North-South Cross Section through the Tuff Pile Area Showing Resistivity Values for the

Lower Tuff Confining Unit 
This page intentionally left blank. 

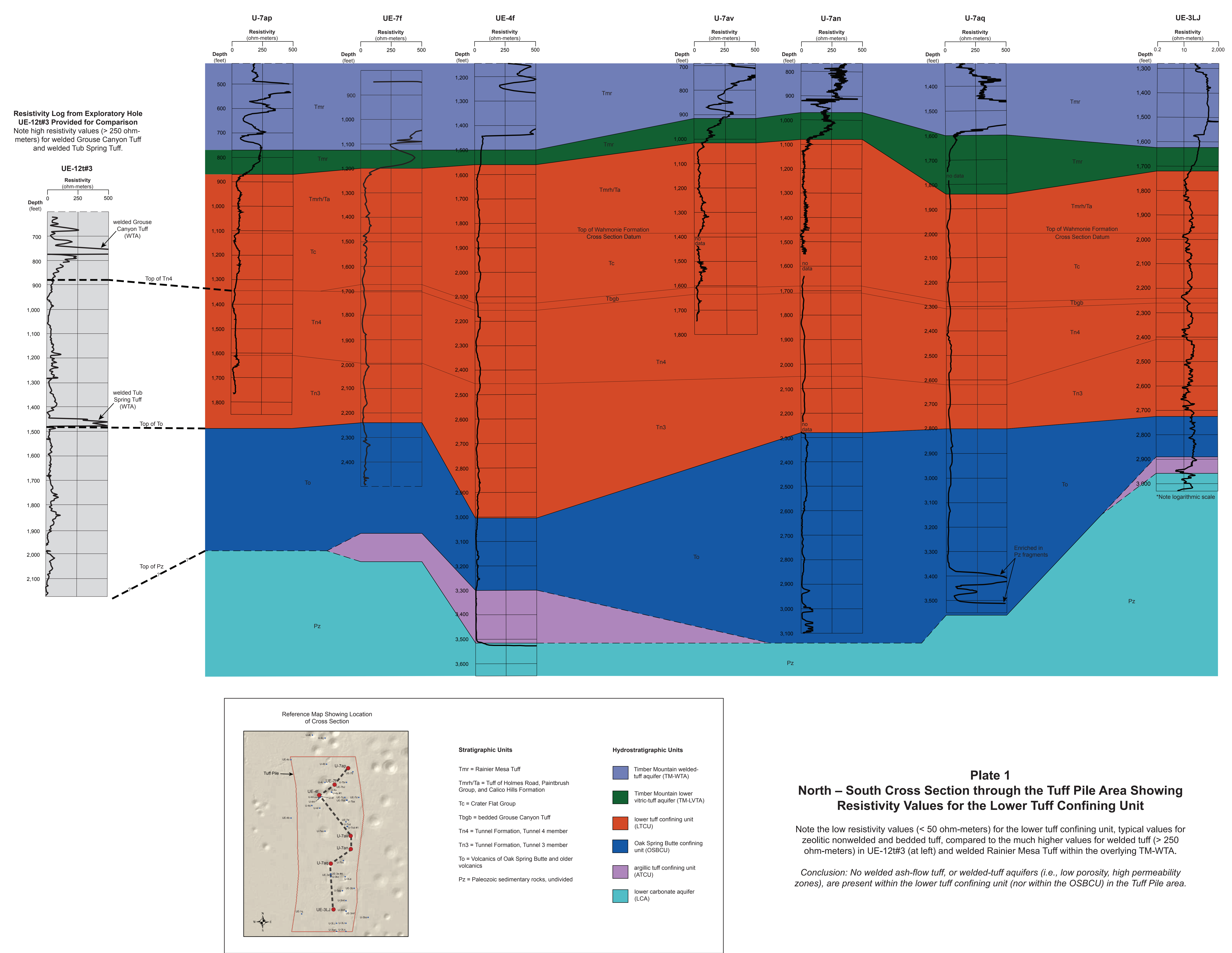

North - South Cross Section through the Tuff Pile Area Showing Resistivity Values for the Lower Tuff Confining Unit

Note the low resistivity values ( $<50$ ohm-meters) for the lower tuff confining unit, typical values for zeolitic nonwelded and bedded tuff, compared to the much higher values for welded tuff (- 250
ohm-meters) in UE-12t\#3 (at left) and welded Rainier Mesa Tuff within the overlying TM-WTA. Conclusion: No welded ash-flow tuff, or welded-tuff aquifers (i.e., low porosity, high permeability
zones), are present within the lower tuff confining unit (nor within the OSBCU) in the Tuff Pile area. 